\title{
Making and Breaking Microliths: A Middle Mesolithic Site at Asfordby, Leicestershire
}

\author{
By LYNDEN P. COOPER ${ }^{1}$, and WAYNE JARVIS ${ }^{1}$ \\ with contributions by \\ ALEX BAYLISS ${ }^{2}$, MATTHEW G. BEAMISH ${ }^{1}$, CHRISTOPHER BRONK RAMSEY ${ }^{3}$, JENNIFER BROWNING ${ }^{1}$, RHEA BRETTELL ${ }^{4}$ \\ GORDON COOK ${ }^{5}$, ADRIAN EVANS ${ }^{4}$, CARL HERON ${ }^{4}$, and RICHARD MACPHAIL $^{6}$
}

Archaeological fieldwork preceding housing development revealed a Mesolithic site in a primary context. A central hearth was evident from a cluster of calcined flint and bone, the latter producing a modelled date for the start of occupation at 8220-7840 cal BC and ending at 7960-7530 cal BC (95\% probability). The principal activity was the knapping of bladelets, the blanks for microlith production. Impact-damaged microliths indicated the re-tooling of hunting weaponry, while microwear analysis of other tools demonstrated hide working and butchery activity at the site. The lithics can be classified as a Honey Hill assemblage type on the basis of distinctive leaf-shaped microlithic points with inverse basal retouch.

Such assemblages have a known concentration in central England and are thought to be temporally intermediate between the conventional British Early and Late Mesolithic periods. The lithic assemblage is compared to other Honey Hill type and related Horsham type assemblages from south-eastern England. Both assemblage types are termed Middle Mesolithic and may be seen as part of wider developments in the late Preboreal and Boreal periods of north-west Europe. Rapid climatic warming at this time saw the northward expansion of deciduous woodland into north-west Europe. Emerging new ecosystems presented changes in resource patterns and the Middle Mesolithic lithic typo-technological developments reflect novel foraging strategies as adaptations to the new opportunities of Boreal forest conditions. While Honey Hill-type assemblages are seen as part of such wider processes their distinctive typological signature attests to autochthonous, regional developments of human groups infilling the landscape. Such cultural insularity may reflect changing social boundaries with reduction in mobility range and physical isolation caused by rising sea level and the creation of the British archipelago.

Keywords: Middle Mesolithic, Honey Hill assemblage, Preboreal-Boreal transition, microliths, soft stone percussion, radiocarbon, microwear study

\section{LOCATION}

The village of Asfordby is located approximately $4 \mathrm{~km}$ west of Melton Mowbray in north Leicestershire, in the
English Midlands (Fig. 1). The site area is on the north-west edge of the village, south of the A6006 off Loughborough Road and adjacent to Captain's

\footnotetext{
${ }^{1}$ University of Leicester Archaeological Services, School of Archaeology and Ancient History, University of Leicester, University Road, Leicester, LE1 7RH, UK

Email: lpc2@leicester.ac.uk

${ }^{2}$ English Heritage, 1 Waterhouse Square, 138-42 Holborn, London, EC1N 2ST, UK

${ }^{3}$ Oxford Radiocarbon Accelerator Unit Research Laboratory for Archaeology, Dyson Perrins Building, South Parks Road, Oxford, OX1 3QY, UK

${ }^{4}$ Archaeological Sciences, University of Bradford, Richmond Road, Bradford, BD7 1DP, UK

${ }^{5}$ Scottish Universities Environmental Research Centre, Rankine Avenue, Scottish Enterprise Technology Park, East Kilbride, G75 0QF, UK

${ }^{6}$ Institute of Archaeology, 31-34 Gordon Square, London, WC1H OPY, UK
} 
Close County Primary School and Community Centre (SK 701 192).

The site is on a slight spur, a southern outlier of higher ground beyond and to the north which eventually rises to $c .170 \mathrm{~m}$ aOD. From the current site where there is a slight crest at $c .78 .5 \mathrm{~m}$ the land falls off in other directions, most noticeably to the south and west dropping down eventually to the valley, with the present course of the river Wreake being $500 \mathrm{~m}$ away. The site is situated slightly down and to the east of the crest, with current ground level at a height of $78.2 \mathrm{~m}$. Within the field in which the site is located the overall drop is some $c .4 \mathrm{~m}$. On the southern and western slopes of the field later Mesolithic material and features of Early Bronze Age (Beaker) date were also identified (Jarvis 2012). Several large flint cores have been discovered $500 \mathrm{~m}$ south-east of the site, and two unfinished pebble hammers, most likely of Mesolithic date, $350 \mathrm{~m}$ to the east (HER reference MLE 7066, fig. 1). The site at Eye Kettleby presents evidence for a larger Mesolithic flint scatter (Finn 2011) but, like the other small Mesolithic sites and find spots in the Wreake Valley, its temporal position in the first half of the Holocene is unknown.

The site has been undeveloped pasture since at least the late 19th century. In the west and south of the field was evidence for medieval ridge and furrow cultivation, but this was absent in the actual area of the current site. Land immediately to the east of the lithic scatter is now a school playing field. Directly to the north are further pasture fields, with a north-east to south-west springfed stream running through the adjacent field.

\section{Circumstances of discovery}

Staged archaeological work was a condition on a planning application for the erection of dwellings with associated infrastructure at The Hawthorns, Asfordby by Jelson Ltd. The overall site development area was c. 1.8 ha. A geophysical survey indicated some potential features although no coherent planforms were discerned, other than a pattern of agricultural features (Smalley 2007). However, a trial trenching evaluation was required and undertaken (Parker 2008). Prehistoric deposits were identified in three areas (Fig. 2), with Areas 1 and 3 producing Late Mesolithic worked flint, Early Bronze Age, and Iron Age features and medieval ridge and furrow (Jarvis 2011; 2012). Area 2, in the north-east of the development, was covered $400 \mathrm{~m}^{2}$, and trial trenching here exposed features of later prehistoric date as well as a Mesolithic flint scatter in a primary context. A subsequent test-pit survey on a $5 \mathrm{~m}$ interval identified the spatial and stratigraphic extent of the scatter (Fig. 3). The lithics were contained within a preserved palaeosol and the range of microlith types suggested it was a Honey Hill assemblage. The occupation was focused, apparently representing a snap-shot of activity. The scatter was concentrated in the east of Area 2, and could be isolated to a $10 \times 10 \mathrm{~m}$ area at the edge of the development (with the scatter continuing into the adjacent primary school playing field). Preservation of the site was not possible so the $100 \mathrm{~m}^{2}$ area was targeted for full excavation, funded jointly by Jelsons Ltd and English Heritage.

\section{Excavation methodology}

The area was divided up and excavated in $1 \mathrm{~m}$ squares within the $10 \times 10 \mathrm{~m}$ grid, each square being handexcavated in spits of c. $20 \mathrm{~mm}$. All finds were plotted in three dimensions by a Global Positioning System, and plans of deposit changes, etc, were produced as necessary after removal of spits. Magnetic susceptibility readings were also taken at $1 \mathrm{~m}$ intervals across each spit. Sampling of all spoil was carried out for finds retrieval by wet sieving using a $2 \mathrm{~mm}$ mesh, but this proportion was reduced to $33 \%$ after assessment work indicated that few finds were being missed during hand excavation. Environmental samples were taken both as control samples and where any concentrations of charcoal or bone were observed. Samples for pollen, mollusc remains, soil micromorphology, and Optical Stimulated Lumenescence dating were also taken.

\section{Project aims and objectives}

The aims and objectives of the project are fully discussed in the original and updated project design documents (Cooper 2010; 2011). These were related to the overarching corporate aims of English Heritage (SHAPE 2007) and period-specific aims outlined in regional and national research agendas (Prehistoric Society 1999; Myers 2006; Knight et al. 2012; Blinkhorn \& Milner 2013).

The key aims and objectives were:

1. Understanding the site formation processes;

2. Dating the occupation;

3. An understanding of the chaine opératoire of the lithic assemblage; 
L.P. Cooper \& W. Jarvis. MAKING \& BREAKING MICROLITHS: MIDDLE MESOLITHIC SITE, ASFORDBY, LEICS
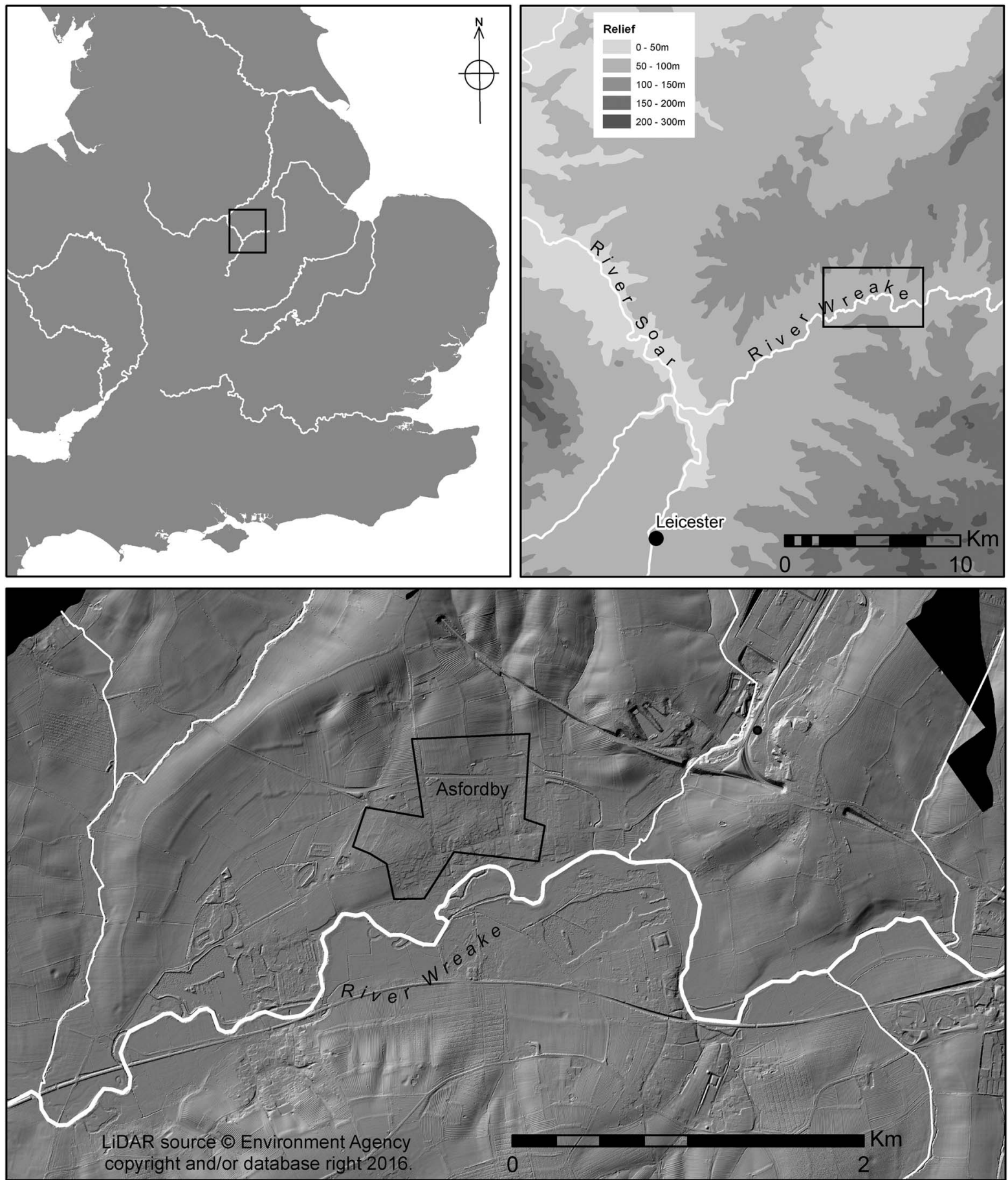

Fig. 1.

Site location with local multi-hill-shade plot of filtered $1 \mathrm{~m}$ LiDAR data with modern buildings and trees removed 


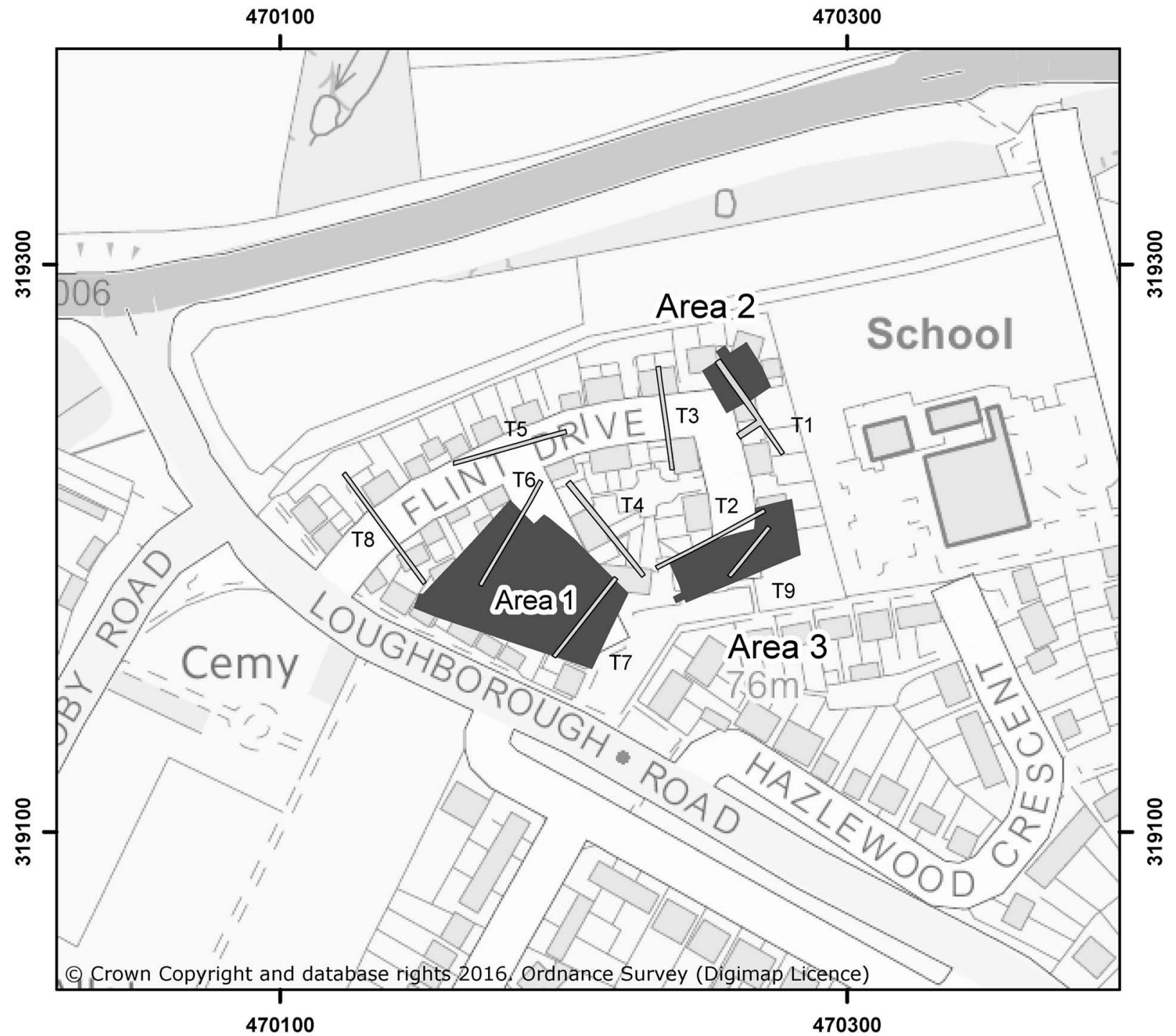

Fig. 2.

Site plan post-development with overlying archaeological trench/area plan

4. An understanding of the contemporary environment and climate;

5. An understanding of the site function(s) and what types of activity occurred there; and

6. A comparison of the site with contemporary sites in the UK and beyond.

\section{GEOLOGY \& GEOMORPHOLOGY}

(Richard Macphail \& Wayne Jarvis)

The area has a mapped cover of Wickham 2 soil association formed in drift over Mesozoic geology
(Macphail 2012). The on-site soils are broadly stagnogleyic argillic brown earths (Oxpasture soil series; Hodge et al. 1983), complicated by a perched 'high' water table, and apparent colluvial infilling of irregularities in the Early Holocene landscape. The perched water table has led to a gleyed Bg horizon at a uniform depth across the site which only reflects later prehistoric and modern soil conditions, and probably not the soil and landscape of the Mesolithic period. The site lies between two north-east to south-west trending buried valleys or channels (Edina 2013) and within $c .50 \mathrm{~m}$ of the easternmost. These may have 


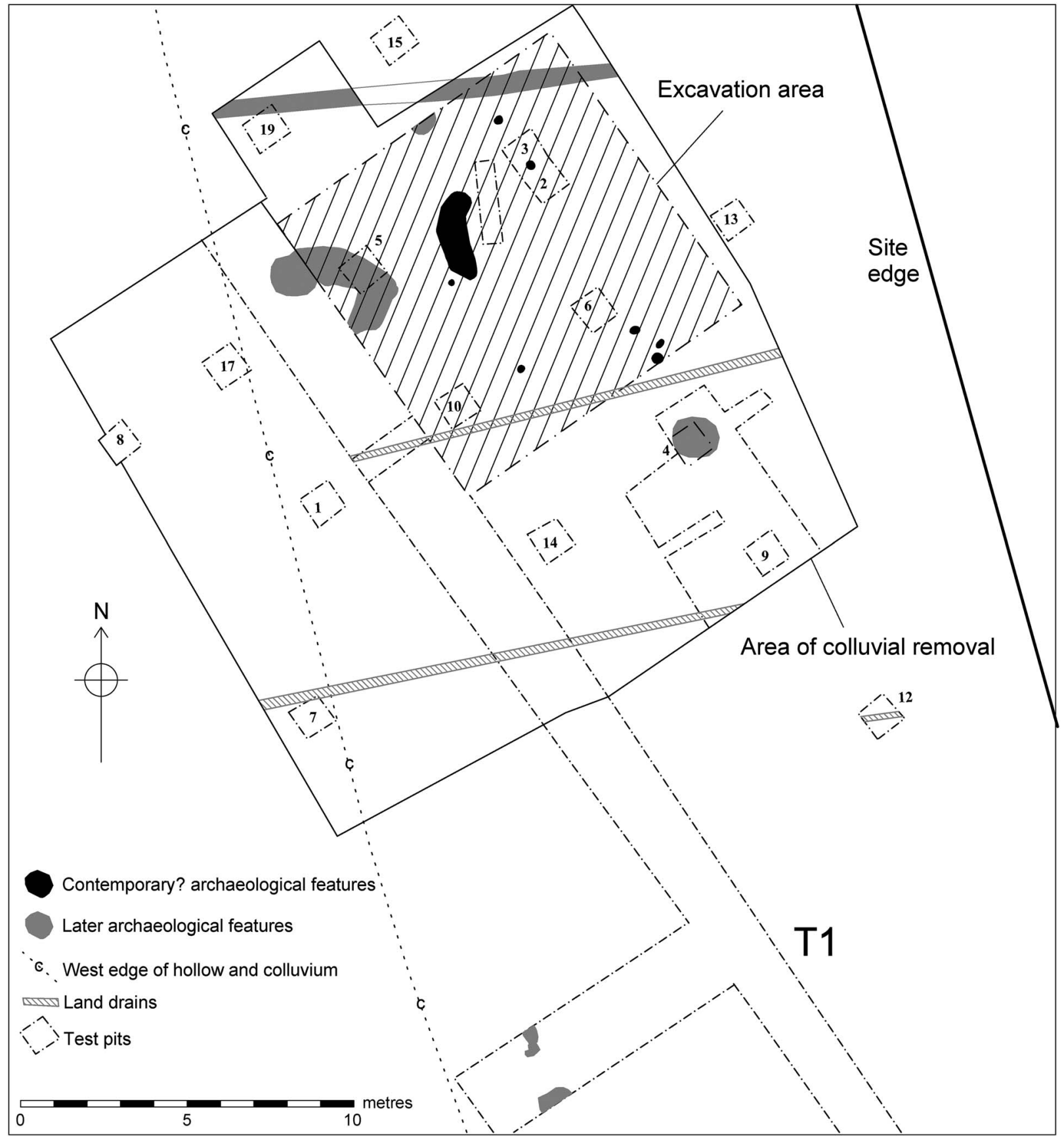

Fig. 3.

Mesolithic area general plan

been small valleys in the Mesolithic but, as with the current site, were most likely infilled during the Holocene, with the smoothing out of an undulating glacial land surface.
Locally the valley of the River Wreake has a cover of brown earths, brown sands, and gleyic brown sands (Wick 1 soil association) formed in glaciofluvial or river terrace drift and an area of this soil cover may be 
preserved at the current site. In the trial trench west of the Mesolithic scatter the possible junction between the different parent materials and soils was visible between soils to the south that are likely stagnogleyic argillic brown earths (with a clay-enriched sandy loam Btg horizon) formed in drift over Mesozoic geology and gleyic brown sands on the north side; this soil has a loamy sand subsoil probably formed in a relict glaciofluvial or river terrace drift. The Mesolithic flint scatter occurs within this thicker loamy sand soil containing few medium pebbles.

Intermittently waterlogged sands and gravels occur at depth. The superficial deposits mapped for the site are Birstall Sand and Gravel (BGS 2013). Very close to the north are Anglian till deposits including the Rotherby and Oadby Members, the latter of which includes abundant flint, some of which is suitable for knapping. The solid geology below consists of late Triassic-early Jurassic deposits of the Scunthorpe Mudstone Formation (SMD; BGS 2013). that within Area 2. Here, the sequence consisted of topsoil, upper subsoil, colluvial deposits, the Mesolithic layer, Mesolithic 'subsoil', and drift 'natural' in sequence (Fig. 4). The buried soil deposits (the colluvia and Mesolithic sequence) below the upper subsoil level only survived in this limited locale in the east of site in what is an infilled hollow at least $20 \mathrm{~m}$ wide (eastwest), more than $80 \mathrm{~m}$ long, and up to $1.5 \mathrm{~m}$ deep at the south. The survival of these buried soils is due partly to this hollow, but also to the absence of historic plough truncation. In contrast, ploughing was evidenced from both the geophysical survey and site observations over the rest of the development area, where the plough had produced a truncated sequence of topsoil, subsoil, and natural drift. This subsoil was in part an artefact of cultivation and followed the characteristic medieval ridge and furrow corrugations, with any earlier soil build-ups below this level having being truncated. Prehistoric features identified elsewhere on site were sealed below this subsoil level.

\section{Stratigraphic sequence}

The general sequence across the development (Areas 1 and the west part of Area 3; Fig. 2) was at variance to

\section{DEPOSIT SEQUENCE IN AREA 2}

The deposit sequence can be summarised as follows; heights where given are at the centre of the $10 \times 10 \mathrm{~m}$ area.

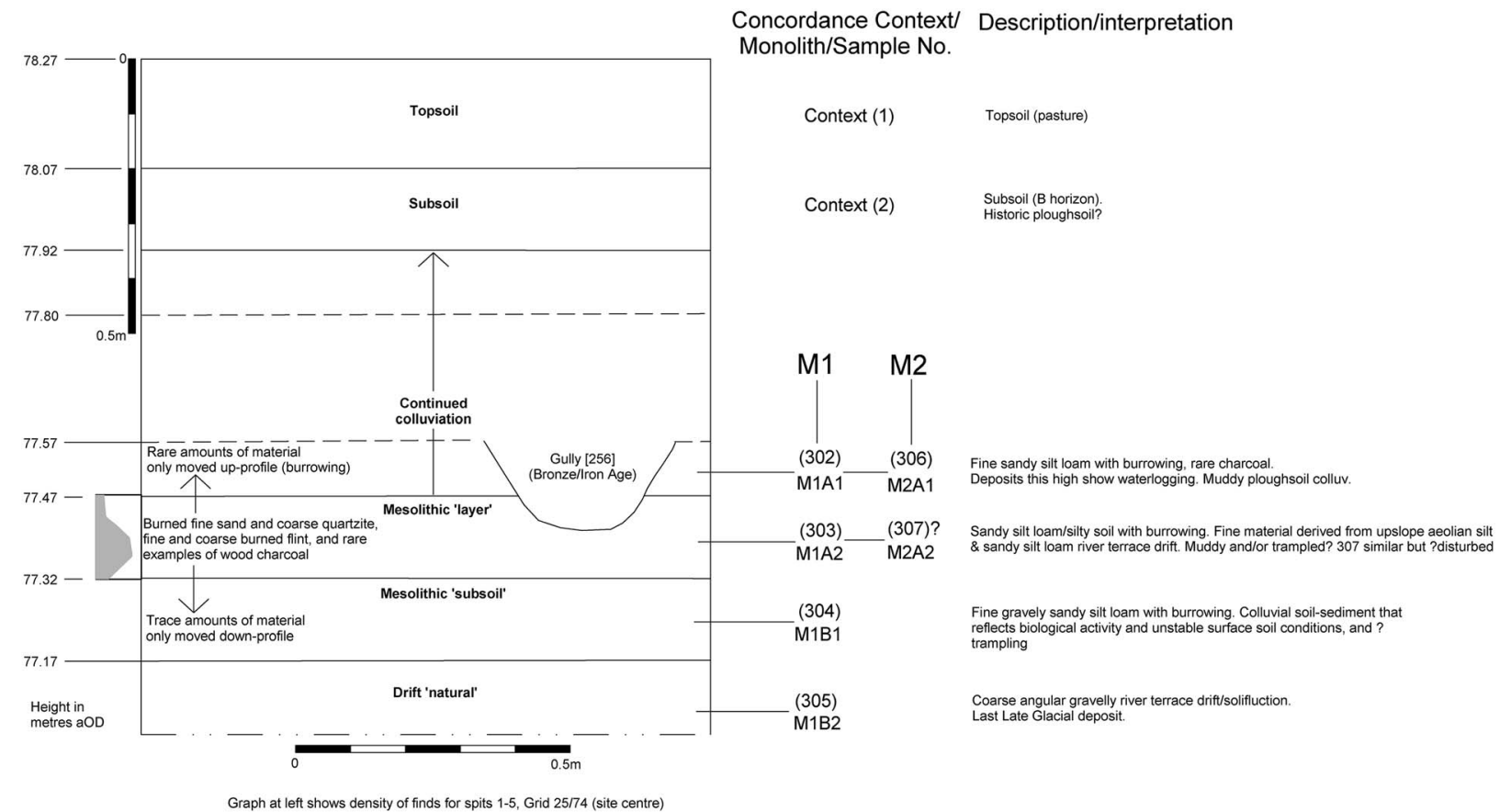

Fig. 4.

Schematic section through the Area 2 deposits 


\section{L.P. Cooper \& W. Jarvis. MAKING \& BREAKING MICROLITHS: MIDDLE MESOLITHIC SITE, ASFORDBY, LEICS}

Topsoil: Context (1). Recorded on site as a mid-brown sandy silt loam, occasional gravels, and trace charcoal. This A-horizon deposit represents the uppermost layer of land under pasture and was present across the whole of the site. It was excavated with a machine (in a $20 \times 20 \mathrm{~m}$ area) at an early stage of works after the sequence was identified during initial test pitting. The current ground level has a slight incline down to the south and east. The deposit was c. $0.20 \mathrm{~m}$ thick, height $78.27-78.07 \mathrm{~m}$ aOD (centre of area).

Subsoil: Context (2). Recorded on site as a midyellowish brown silty clay loam, occasional gravels, trace charcoal. This is a perhaps relatively recent ploughsoil B-horizon. Features of prehistoric date survived directly below this elsewhere on site, where earlier ploughtruncation of underlying deposits had occurred. This deposit was present across the whole of the site and was also removed during the overburden stripping. Depth from current ground level c. $0.2-0.35 \mathrm{~m}$, height 78.07-77.92 $\mathrm{m}$ aOD.

Colluvial deposits: General context (3), lower levels $0.7 m+$ down $=$ contexts (302), (306). Observed on site as a mid-grey brown sandy loam, only occasionally gravelly. Deposits at this depth show waterlogging (gleying). Recorded across the whole area, thickening to the east and south, with $1.5 \mathrm{~m}$ of sandy colluvium being identified to the south where the hollow was deepest. Depth from current ground level in centre of area $c .0 .35-0.85 \mathrm{~m}$, height $77.92-77.47 \mathrm{~m}$ aOD. The lower $c .0 .1 \mathrm{~m}$ of this colluvium was cut by later prehistoric features (at a height of $77.57 \mathrm{~m}$ aOD). Micromorphology: Burrowed fine sandy silt loam. Muddy ploughsoil colluvium. Finds: Only rare anthropogenic material moved up-profile (by burrowing) including rare/trace charcoal and rare burned flint.

The Mesolithic 'layer': Contexts (303), (307, similar but with possibly intrusion). Observed on site as a pale to mid-greyey brown frequently iron panned sandy silt loam. Recorded across the whole area. Slight slope down to south and east. Deposit depth c. 0.85-1.0 m from current ground level, 77.47-77.32 m aOD. Micromorphology: Fine material derived from upslope aeolian silt and sandy silt loam river terrace drift. Burrowed sandy silt loam/silty soil. Muddy and/or trampled burnt fine sand and coarse quartzite, fine and coarse burnt flint, rare charcoal. Frequency of finds from spits $1-5$ within this layer (spits $c .20 \mathrm{~mm}$ ) range from 15 (spit 1 ) to 85 (spit 4), with a clear peak being at spits 3-4 (finds count 75-85 respectively).

The Mesolithic 'subsoil': Context (304). Observed on site as a browny grey somewhat gravelly clayey sand. Deposit depth c. 1.0-1.15 $\mathrm{m}$ from current ground level, 77.32$77.17 \mathrm{~m}$ aOD. Micromorphology: Burrowed fine gravely sandy silt loam. A colluvial soil-sediment that reflects biological activity and unstable surface soil conditions and possibly trampling. Trace amounts of anthropogenic material only moved down-profile, including very fine charcoal, calcined angular flint, and single sub-rounded burned quartzite.

The 'natural': Context (305). The drift 'natural' substratum, observed on site as a browny grey silty sand and gravel. Deposit depth $c .1 .15->1.3 \mathrm{~m}$ from current ground level, below $77.17 \mathrm{~m}$ aOD. Micromorphology: Coarse angular gravelly river terrace drift/ solifluction deposit, last Late Glacial deposit. Limited excavation indicated only rare flint debitage transported (largely by bioturbation) from upper deposits down into this part of the soil profile.

Deposits associated with Mesolithic occupation were column sampled and studied employing soil micromorphology. Investigation was carried out on six thin sections from two test pit monoliths to characterise and define the nature of the deposits observed on site (monoliths M1 and M2, test pits TP20 and TP22 see Appendix S1, Tables S1 \& S2).

\section{Samples and methods}

Selected areas from a $300 \mathrm{~mm}$ long monolith (TP20) and a $130 \mathrm{~mm}$ long monolith (TP22) were resin impregnated and thin sections manufactured by Spectrum Petrographics (Goldberg \& Macphail 2006; Murphy 1986). Thin sections were studied at magnifications from $\times 1$ to $\times 200 / 400$ under plane polarised light (PPL), crossed polarised light (XPL), oblique incident light (OIL) and using fluorescent microscopy (blue light - BL).

\section{Results and discussion}

Full descriptions and soil micromorphological interpretations are presented in Appendix S1, Tables S1 \& S2.

\section{Site formation processes}

The soil-sediments have undergone a complex series of processes, that are partially understood on the basis of the studies from the site in general and the monolith results in particular. For example, an iron-depleted zone can be discerned above a discontinuous iron pan, below which sediments are more reddish and iron rich. This iron pan, however, does not strictly mark the boundary between the last Late Glacial coarse gravelly and clayey solifluction deposits (contexts 305 and 307), and the overlying Holocene soil-sediments (contexts 304 and 306) (cf. Catt 1986). It is simply a post-depositional effect of waterlogging (Bouma et al. 1990; Lindbo et al. 2010) in overlying soil-sediments over the generally impermeable geology and more clay-rich solifluction deposits. A local spring and general site waterlogging are all a similar effect. 
It is clear that Holocene soils (which only include fine ferruginous gravel) contain fine burnt Mesolithic quartz sand and flint that have been mixed by burrowing into the preHolocene sediments. It is not quite clear exactly how the Mesolithic soil-sediment (contexts 304 and 306) formed, as it has traits suggesting both bioturbation and muddy colluvial formation. It is also possible that muddy trampling occurred. Charcoal and fine and coarse flint artefacts are present - and possibly also of quartzite. The flints can be very much larger $(\max 21 \mathrm{~mm})$ than the rest of the clasts $(\sim 4 \mathrm{~mm})$ in the soilsediment, and are thus likely to be relatively in situ and not simply derived material. Equally, the presence of charcoal in the same contexts and as very fine inclusions, albeit in trace amounts, in the muddy soils, indicates that this is a record of very localised occupation. Moreover, the overlying colluvial soils (contexts 302 and 304; Kwaad \& Mücher 1977; 1979) are clearly sealing the underlying Mesolithic soil-sediment, and no burnt flint was discerned (the exact provenance of examples of ferruginised charcoal is unknown). Lastly, another complication affecting the soil-sediments is the presence of silty microfabrics in the generally sandy loams which may derive from local upslope bi-sequal soils, where loess was deposited over the river terrace drift (cf. the Chilterns: Avery 1964; Bolt et al. 1980; Catt 1978).

\section{Conclusion}

The sediments have undergone a complex site formation history, including solifluction of likely last Late Glacial deposits. These contain much coarse angular ironstone of river terrace drift origin. These were superseded by the Mesolithic soil-sediment, which has traits suggesting both bioworking and muddy colluvial formation with possible muddy trampling occurring. This deposit is much less gravelly with fine gravel and a silt presence which may indicate some loess input. Artefacts include fine burned sand, coarse burnt quartzite, fine and coarse burnt flint, and rare examples of wood charcoal. The coarse flint artefacts are sharply angular and very much larger than the natural clasts, demonstrating an unlikely derived origin. The Mesolithic soil-sediment is clearly sealed by later Holocene colluvium probably formed through ploughsoil colluviation, again indicating the integrity of the Mesolithic occupation (eg, combustion zone) material.

\section{RADIOCARBON DATING AND CHRONOLOGICAL MODELLING}

(Alex Bayliss, Wayne Jarvis, Christopher Bronk

Ramsey, Gordon Cook \& Lynden P. Cooper)

Twenty-three samples of calcined mammal bone from the buried soil at Asfordby were submitted for radiocarbon dating to the Scottish Universities Environmental Research Centre and the Oxford Radiocarbon Accelerator Unit. All samples were processed using the protocol for dating cremated bone described by Lanting et al. (2001). Those dated at the Scottish Universities Research and Reactor Centre were combusted to carbon dioxide, graphitised, and dated by Accelerator Mass Spectrometry (AMS) using methods outlined in Vandeputte et al. (1996), Slota et al. (1987), and Xu et al. (2004). Those dated at the Oxford Radiocarbon Accelerator Unit were combusted, graphitised, and dated by AMS as described by Brock et al. (2010), Dee and Bronk Ramsey (2000), and Bronk Ramsey et al. (2004).

Five samples failed in laboratory processing. SF4996 (23/78 spit 1) produced widely divergent radiocarbon ages from duplicate analyses at Oxford, and so this sample was failed on the basis of the lack of reproducibility between replicate analyses. There was a discolouration of the carbonate and orthophosphoric acid noted during the processing of this sample, which was also noted during the processing of OxA-25728 and OxA-25746. These results must therefore be treated with a degree of caution. One further sample, SF8383 (30/75), produced sufficient carbon for dating but failed in the SUERC AMS. The other three samples, SAM323 $(21 / 78$ spit 4), SAM5377 (25/73 spit 4) and SAM6848 (29/75 spit 6), produced insufficient carbon for dating.

The results are conventional radiocarbon ages (Stuiver \& Polach 1977) and are listed in Table 1. These ages have been calculated using the fractionation correction provided by the $\delta^{13} \mathrm{C}$ values measured on the dated material in the AMS. These values include both the natural isotopic composition of the sample and fractionation that occurs during laboratory processing. They are not reported. The $\delta^{13} \mathrm{C}$ reported in Table 1 are those measured on subsamples of the combusted $\mathrm{CO}_{2}$ by conventional mass spectrometry. In the case of cremated bone, the meaning of these values is currently unclear, as the natural isotopic ratio of the original bone has been fractionated during both the ancient cremation process and by the selective acid digestion of the bone used during pre-treatment. They are reported, however, in the hope that their meaning will become clear in the future.

The calibrated date ranges for the samples have been calculated using the maximum intercept method 
TABLE 1: RADIOCARBON DATES FROM ASFORDBY

\begin{tabular}{|c|c|c|c|c|c|c|}
\hline Lab. no. & Sample ref. & Context & $\begin{array}{c}\text { Radiocarbon } \\
\text { age (ВР) }\end{array}$ & $\begin{array}{l}\delta^{13} \mathrm{C} \\
(\% \circ) \\
\end{array}$ & $\begin{array}{l}\text { Calibrated date } B C \\
(95 \% \text { probability) }\end{array}$ & $\begin{array}{l}\text { Calibrated date } B C \\
(68 \% \text { probability) }\end{array}$ \\
\hline OxA-25728 & SF4998 (22/77sp1) & $\begin{array}{l}\text { calcined frag. medium-large mammal } \\
\text { bone from buried soil in area of } \\
\text { postulated west hearth. }\end{array}$ & $8690 \pm 39$ & -24.8 & $7800-7590$ & $7750-7600$ \\
\hline OxA-25747 & SF1136 (21/78sp3) & as above & $8876 \pm 40$ & -26.4 & $8240-7820$ & $8210-7950$ \\
\hline SUERC-38114 & SF4999 (22/78sp1) & as above & $8600 \pm 35$ & -26.8 & $7650-7570$ & $7610-7580$ \\
\hline SUERC-38119 & SF7258 (21/77sp7) & as above & $8690 \pm 35$ & -21.9 & $7790-7590$ & $7750-7600$ \\
\hline OxA-27124 & SF244 (26/76sp3) & $\begin{array}{l}\text { calcined frag. medium-large mammal } \\
\text { bone from buried soil in area of } \\
\text { postulated east hearth. }\end{array}$ & $8800 \pm 45$ & -26.0 & $8200-7680$ & $7970-7750$ \\
\hline $\mathrm{OxA}-27125$ & SAM1465 (27/75sp3) & as above & $8870 \pm 45$ & -27.0 & $8230-7740$ & $8180-7820$ \\
\hline OxA-25746 & SAM265 (22/74sp3) & as above & $8734 \pm 39$ & -26.3 & $7960-7600$ & $7800-7650$ \\
\hline OxA-25748 & SF1398 (28/75sp3) & as above & $8885 \pm 40$ & -26.1 & $8240-7830$ & $8220-7950$ \\
\hline OxA-25751 & SF1779 (28/74sp3) & as above & $8848 \pm 39$ & -25.4 & $8220-7750$ & $8190-7930$ \\
\hline SUERC-38118 & SF6330 (26/73sp5) & as above & $8575 \pm 35$ & -25.4 & $7610-7570$ & $7600-7580$ \\
\hline OxA-27068 & SF135 (23/77sp2) & $\begin{array}{l}\text { calcined frag. medium-large } \\
\text { mammal bone from buried soil } \\
\text { in central area }\end{array}$ & $8471 \pm 35$ & -26.6 & $7590-7480$ & $7580-7520$ \\
\hline OxA-27069 & SAM7464 (22/75sp7) & as above & $8759 \pm 37$ & -27.7 & $7960-7610$ & 7940-7730 \\
\hline $\mathrm{OxA}-27070$ & SAM5249 (24/73sp4) & as above & $8825 \pm 40$ & -21.5 & $8210-7740$ & $8170-7810$ \\
\hline SUERC-42079 & SF175 $(23 / 73 \mathrm{sp} 2)$ & as above & $8278 \pm 26$ & -23.8 & $7460-7180$ & $7450-7300$ \\
\hline SUERC-42080 & SAM8052 (24/76sp9) & as above & $8898 \pm 27$ & -26.7 & $8230-7950$ & $8220-7960$ \\
\hline OxA-27101 & SF762 (30/77sp4) & $\begin{array}{l}\text { calcined frag. medium-large mammal bone from } \\
\text { buried soil in north-east area }\end{array}$ & $8345 \pm 40$ & -25.7 & $7530-7310$ & $7490-7350$ \\
\hline SUERC-38120 & SF7381 (30/76sp5) & as above & $8930 \pm 35$ & -21.0 & $8250-7960$ & $8240-7990$ \\
\hline SUERC-38121 & SF7431 (30/76sp6) & as above & $8705 \pm 35$ & -26.4 & $7820-7600$ & $7750-7610$ \\
\hline
\end{tabular}


(Stuiver \& Reimer 1986), and are quoted with end points rounded outwards to ten years. The probability distributions of the calibrated dates, calculated using the probability method (Stuiver \& Reimer 1993) are those shown in outline in the figures. They have been calculated using OxCal v4.1.7 (Bronk Ramsey 2009) and the current internationally-agreed atmospheric calibration dataset for the northern hemisphere, IntCal09 (Reimer et al. 2009).

\section{Chronological modelling}

The radiocarbon dates from Asfordby clearly fall into a coherent group concentrated on the first half of the 8th millennium cal BC. This suggests that all the dated fragments of bone do relate to the Mesolithic use of the site. The measurements are not, however, statistically consistent $\left(T^{\prime}=565.3 ; T^{\prime}(5 \%)=27.6\right.$; $\mathrm{df}=17$; Ward \& Wilson 1978), and so they certainly represent more than one episode of activity.

Simple visual inspection of the calibrated radiocarbon dates does not allow us to assess the date of Mesolithic activity at Asfordby accurately, since the calibration process does not allow for the fact that this group of radiocarbon dates are related - they all come from the same site. Bayesian statistical modelling is required to account for this dependence (Buck et al. 1992; Steier \& Rom 2000; Bronk Ramsey 2000; Bayliss et al. 2007), which we have undertaken using OxCal v.4.1.7 (Bronk Ramsey 1995; 1998; 2009). Date ranges from these models are given in italics to distinguish them from simple, calibrated radiocarbon dates.

Model 1 (Fig. 5) interprets the Mesolithic activity as a continuous period of occupation. This has good

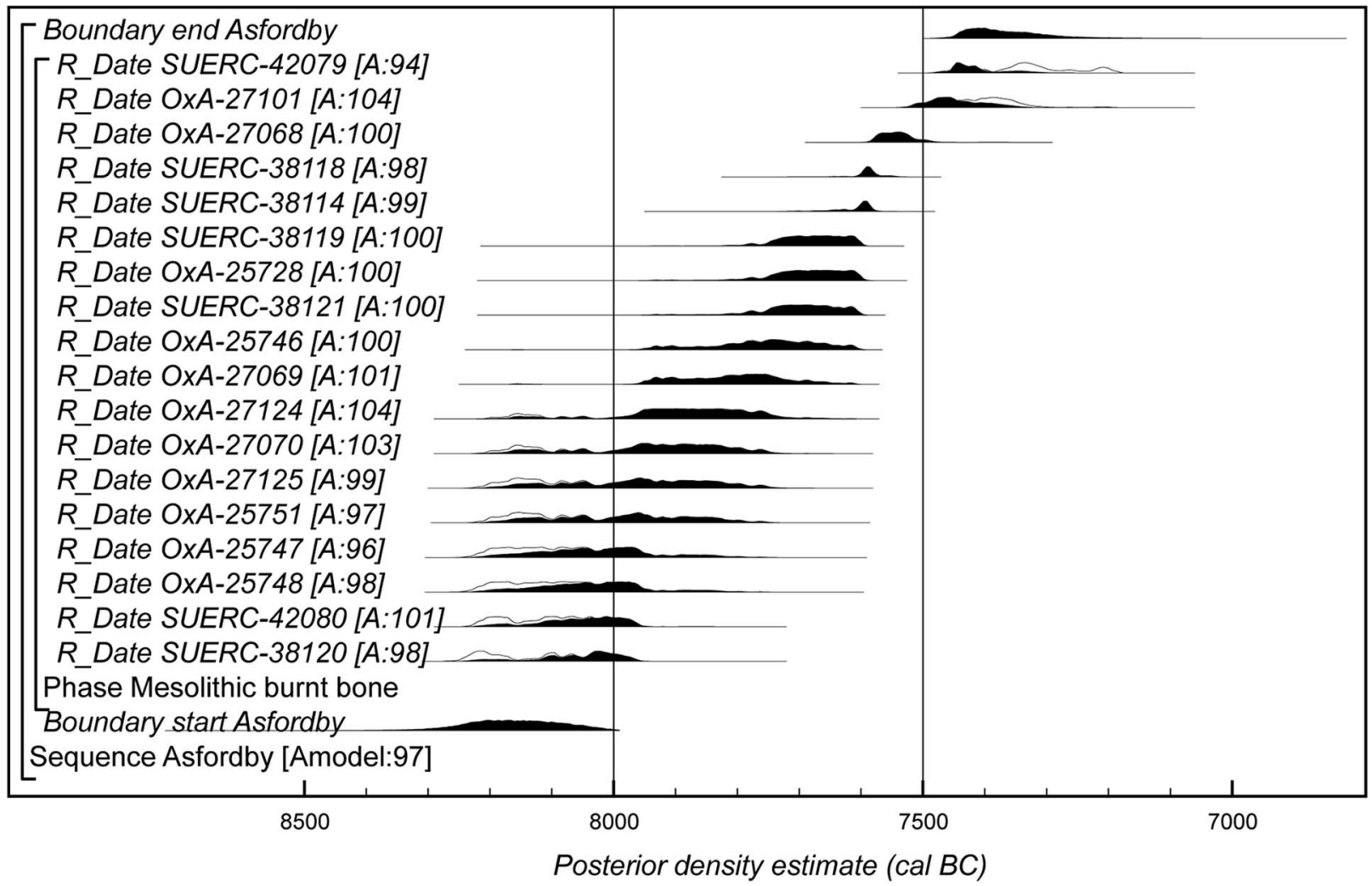

Fig. 5.

Probability distributions of dates from Asfordby (model 1). Each distribution represents the relative probability that an event occurs at a particular time. For each of the dates two distributions have been plotted: one in outline, which is the result of simple radiocarbon calibration, and a solid one, based on the chronological model used. Distributions other than those relating to particular samples correspond to aspects of the model. For example, the distribution 'start Asfordby' is the estimated date when Mesolithic activity on the site began. The large square brackets down the left-hand side along with the OxCal keywords define the overall model exactly 


\section{L.P. Cooper \& W. Jarvis. MAKING \& BREAKING MICROLITHS: MIDDLE MESOLITHIC SITE, ASFORDBY, LEICS}

overall agreement (Amodel: 97; Bronk Ramsey 1995, $429)$, and suggests that this activity began in 8310 $8000 \mathrm{cal} \mathrm{BC}$, probably in $8240-8080 \mathrm{cal} \mathrm{BC} 168 \%$ probability). The activity ended in 7470-7220 cal $B \mathrm{C}$ (95\% probability; end Asfordby; Fig. 5), probably in $7450-7330$ cal $B C(68 \%$ probability $)$. This model suggests that activity continued on the site for 570 1020 years (95\% probability; distribution not shown), probably for 670-900 years (68\% probability).

We do not find this model convincing, as we do not envisage the site as being occupied continuously for so many centuries. This was obviously a persistent place during the 8th millennium, but perhaps episodic visitation is more likely. With this in mind we investigated the statistical consistency of the radiocarbon measurements in more detail. The results fall into a minimum of five statistically consistent groups (Fig. 6). This means that there was a minimum of five discrete episodes of Mesolithic activity on the site. There may, however, in fact have been many more, as for example multiple episodes falling on a plateau in the calibration might well give statistically consistent radiocarbon ages (Fig. 6, A), whereas multiple episodes falling on a steep section of curve (Fig. 6, B) probably would not.

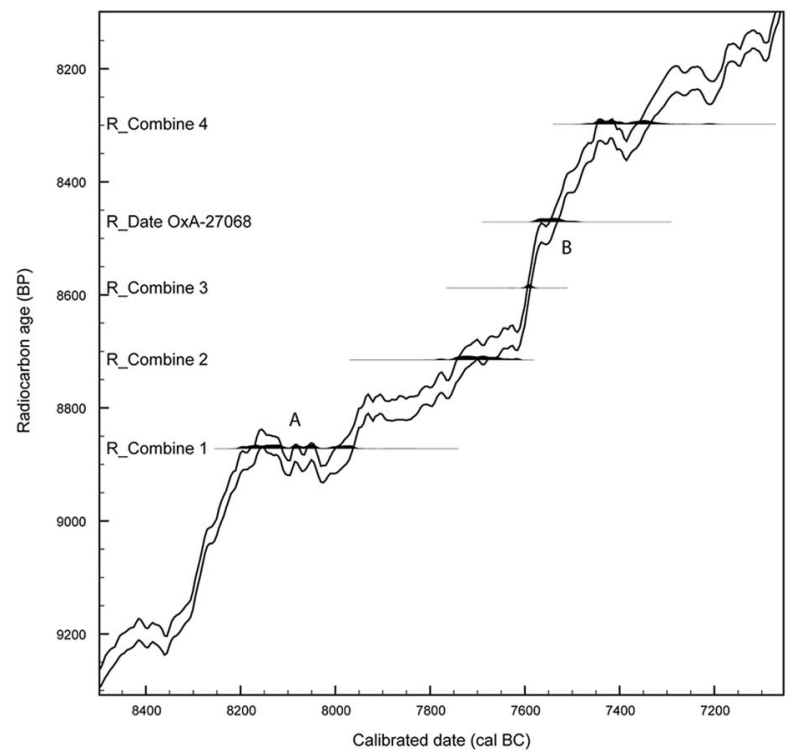

Fig. 6.

Calibrated distributions of the weighted means of the minimum number of statistically consistent groups of radiocarbon measurements from Asfordby, illustrating the effect of the shape of the calibration curve on the statistical consistency of radiocarbon ages from episodes of activity at different calendar dates
Model 2 combines this episodic character of activity at Asfordby with the spatial spread of the dated samples. First we considered the radiocarbon measurements from the immediate vicinity of two postulated hearths. The east hearth was identified from a cluster of burnt lithics and calcined bone, together with enhanced magnetic susceptibility (Fig. 7). Subsequent spatial analysis has confirmed the hearth position. A second postulated west hearth was based upon a discrete cluster of calcined bone to the north-west of the excavated area. There are six measurements from the immediate area of the east hearth, but these do not form a statistically consistent group $\left(\mathrm{T}^{\prime}=46.5 ; \mathrm{T}^{\prime}(5 \%)=11.1 ; \mathrm{df}=5\right)$. If however, $\mathrm{SF} 6330$ (SUERC-38118) is interpreted as derived from a later episode of activity, then the remaining measurements from the hearth are statistically consistent $\left(\mathrm{T}^{\prime}=8.4\right.$; $\left.\mathrm{T}^{\prime}(5 \%)=9.5 ; \mathrm{df}=4\right)$. There are four radiocarbon measurements from the west hearth. Again these do not form a statistically consistent group $\left(\mathrm{T}^{\prime}=27.9\right.$; $\left.\mathrm{T}^{\prime}(5 \%)=7.8 ; \mathrm{df}=3\right)$. SF1136 (OXA-25747) is clearly residual. When this is removed the remaining three measurements are statistically consistent $\left(T^{\prime}=4.2\right.$; $\left.\mathrm{T}^{\prime}(5 \%)=6.0 ; \mathrm{df}=2\right)$. So, on both statistical and spatial grounds, we have identified two relatively discrete episodes of activity associated with the two hearth features postulated on archaeological grounds. There has obviously been post-depositional movement, but a coherent remnant of the pattern of past activity is discernible. The lithic and spatial analysis suggest that most of the activities at Asfordby were focused around the principal east hearth, occurring in the earlier period indicated by the dating programme. The remaining radiocarbon dates clearly represent a number of later visits to the site, although specific activities related to these events cannot be identified on the ground.

This model also has good overall agreement (Amodel: 77; Fig. 8). It suggests that Mesolithic activity at Asfordby began in 8360-8000 cal BC $(95 \%$ probability; start Asfordby; Fig. 8) or 8240-8050 cal $B C(68 \%$ probability). It ended in $7460-7160$ cal $B C$ (95\% probability; end Asfordby; Fig. 8 or in 74407300 cal $B C(68 \%$ probability). Mesolithic activity on the site occurred for a period of 580-1110 years $(95 \%$ probability; use Asfordby; Fig. 9) or 670-930 years (68\% probability).

The east hearth was in use between $8220-7840 \mathrm{cal} B \mathrm{BC}$ (95\% probability; start east; Fig. 9) probably 8100 7890 cal $B C$ and $7960-7530$ cal $B C$ (95\% probability; end east; Fig. 9) or 7930-7730 cal BC (68\% probability). 


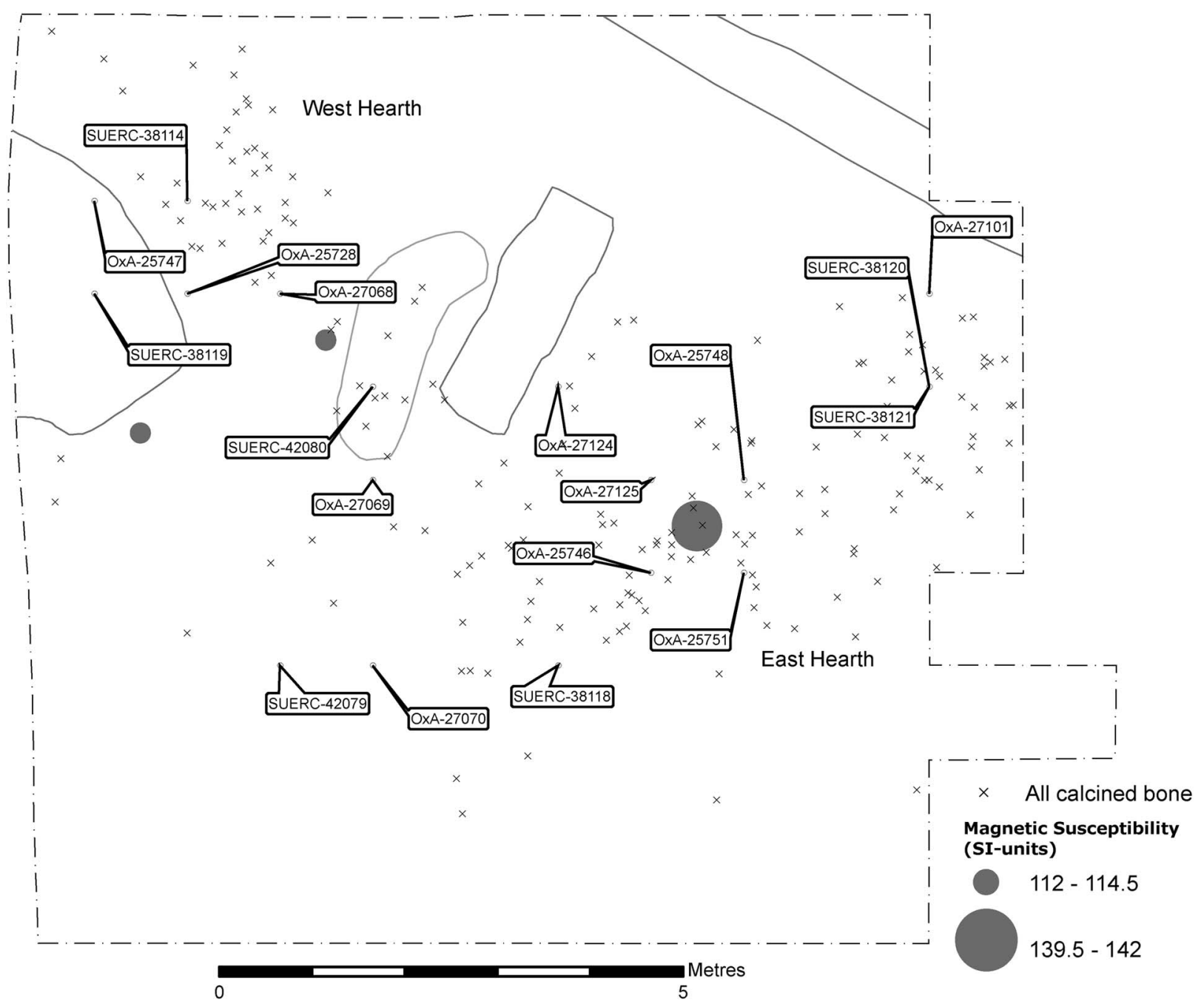

Fig. 7.

Distribution plot of calcined bone and radiocarbon samples with positions of high value magnetic susceptibility readings and putative hearth locations

The probability distribution for the number of years during which the east hearth was in use is heavily skewed towards a shorter duration (use east hearth; Fig. 9).

The west hearth was in use between 7920-7600 cal $B C(95 \%$ probability; start west; Fig. 9) or 7760 7620 cal $B C(68 \%$ probability) and $7710-7430$ cal $B C$ (95\% probability; end west; Fig. 9) or 7650-7540 cal $B C(68 \%$ probability). Again, the probability distribution for the number of years during which the west hearth was in use is also heavily skewed towards a shorter duration (use west hearth; Fig. 9). It is $74 \%$ probable that the west hearth came into use after activity around the east hearth had ended.
There are no other dated sites of Honey Hill assemblage type. However, there is a typological linkage between Honey Hill and the Horsham assemblages of southern England: both assemblage types include microliths that can be described as points with inverse basal retouch (Saville 1981b; Reynier 2005). Such microlith types are not found in the presumed earlier Mesolithic Star Carr and Deepcar assemblages, or the later Mesolithic geometric microlith assemblage types. Of sites associated with Horsham type assemblages only those from Kettlebury, Surrey and Longmoor I, Hampshire have radiocarbon dates. Four statistically consistent radiocarbon measurements are available on 


\section{L.P. Cooper \& W. Jarvis. MAKING \& BREAKING MICROLITHS: MIDDLE MESOLITHIC SITE, ASFORDBY, LEICS}

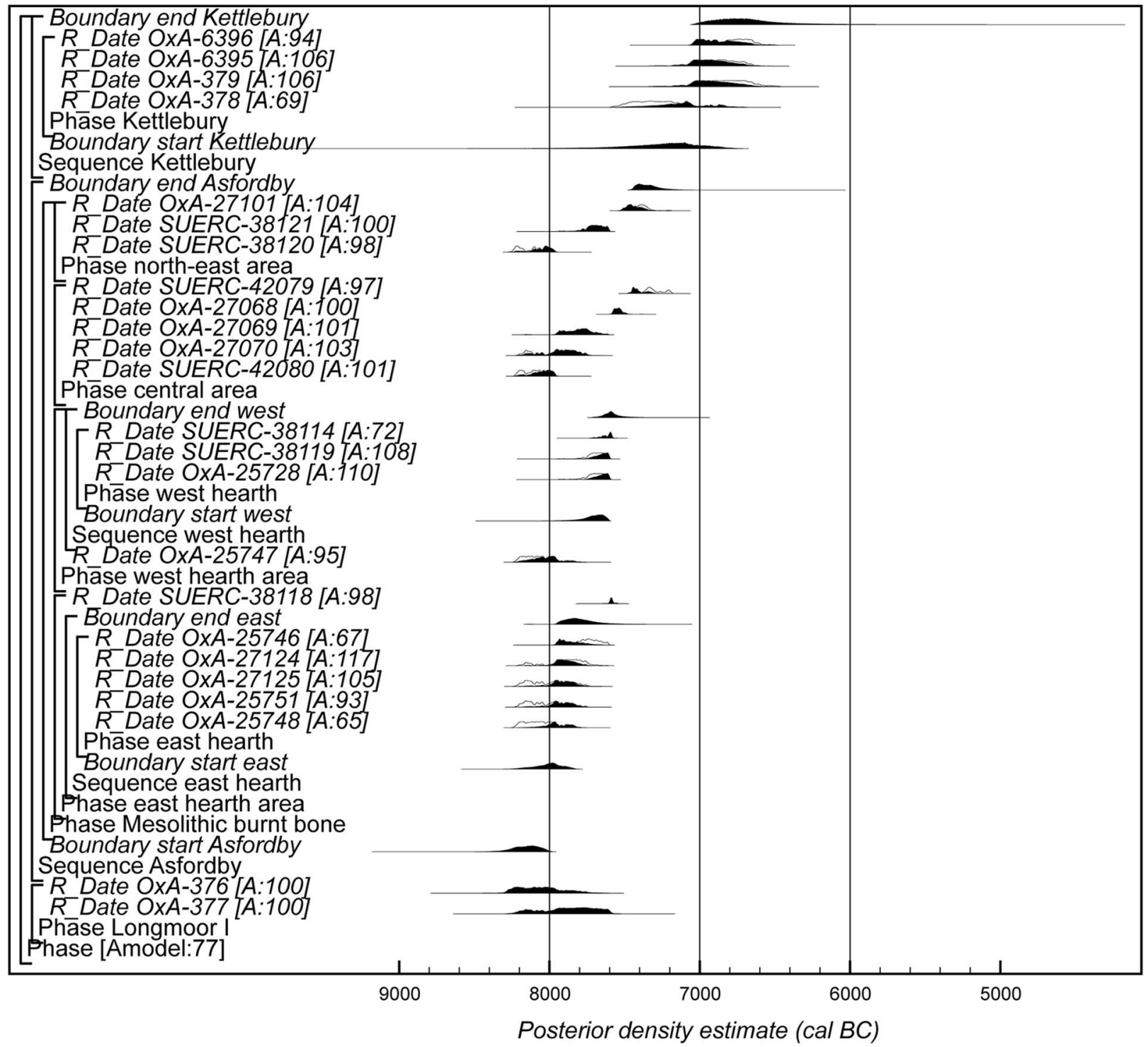

Fig. 8.

Probability distributions of dates from Asfordby (model 2, preferred interpretation), Kettlebury (after Waddington et al. 2007, fig 15.17), and Longmoor I. The format is identical to that of Figure 5. The large square brackets down the left-hand side along with the OxCal keywords define the overall model exactly

hazelnut shell from Kettlebury $\left(\mathrm{T}^{\prime}=7.3 ; \mathrm{T}^{\prime}(5 \%)=7.8\right.$; $\mathrm{df}=3$; Waddington et al. 2007, table 15.1), and two statistically consistent radiocarbon measurements are available on hazelnut shell from Longmoor I ( $\mathrm{T}^{\prime}=1.3$; $\mathrm{T}^{\prime}(5 \%)=3.8 ; \mathrm{df}=1$; Waddington et al. 2007, table 15.1). This suggests that the occupation of both sites was relatively brief.

Figure 9 shows the chronology for Asfordby in comparison with those from Longmoor I and
Kettlebury. Longmoor I appears to be contemporary with the earlier years of occupation at Asfordby and Kettlebury is probably $(64 \%$ probable $)$ slightly later than the end of occupation at Asfordby. The late Roger Jacobi had some doubts about the validity of the Kettleby dates speculating that they may result from activities unconnected with the lithic assemblage (Jacobi pers. comm.; Conneller et al. 2016a). Similarly, we regard the later dates from Asfordby as 
THE PREHISTORIC SOCIETY

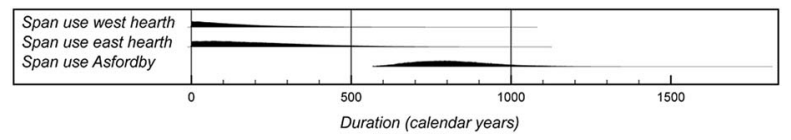

Fig. 9.

Probability distributions of the number of years during which the site and hearths at Asfordby were in use

indicative of activities unconnected with the main lithic assemblage.

\section{LITHIC ANALYSIS}

\section{(Lynden P. Cooper)}

All hand-recovered pieces were classified and entered onto a database with a tri-partite build (tools/byproducts, debitage and cores) using the find numbers assigned on site. All pieces were recorded by flint type, degree of patination, and whether they were burnt or calcined. Some heavily patinated pieces with recent breaks showed glossy interiors indicative of burning, but whose outer surfaces were patinated but showed no definite evidence of combustion. Thus there is very likely an under-representation of burnt pieces particularly smaller pieces. Technological and metrical analysis was undertaken on debitage from alternate squares of the $74 \mathrm{~m}$ North transect. Any tools or tool by-products recovered from the wet-sieving programme were given individual numbers and added to the database. The assemblage breakdown is presented in Table 2 .

\section{Raw material}

The raw material was mostly semi-translucent flint nodules with a thin smooth cortex, typical for the region (recorded on the database as 'local'). This flint type arrived in the East Midlands with the Oadby Till of the Anglian Glaciation. When examined as a split nodule it is very dark greyish brown (Munsell 10YR 4/2) to greyish brown (10YR 5/2) but debitage can appear lighter in colour due to its translucency. The raw material is available from the site locale, the Birstall Member sand and gravel terrace deposit. The large open area excavations elsewhere at the site provided an opportunity to test the on-site available flint resource. Although a high proportion of material had thermoclastic flaws some good quality semitranslucent flint nodules were also recovered. The flint could have been grubbed up but it seems more likely that tree throws would have provided an easier collecting opportunity. Other local sources would be
TABLE 2: BREAKDOWN OF THE ASSEMBLAGE

\begin{tabular}{lrr}
\hline Flint tools & $n$ & $\%$ \\
\hline Microliths & 129 & 65.8 \\
Scrapers & 25 & 12.8 \\
Burins & 9 & 4.6 \\
Retouched flake & 13 & 6.6 \\
Retouched blade & 5 & 2.6 \\
Piercer & 5 & 2.6 \\
Micro-denticulate & 1 & 0.5 \\
Axe & 1 & 0.5 \\
Percussor & 3 & 1.5 \\
Strike-a-light & 1 & 0.5 \\
Utilised bladelet & 2 & 1.0 \\
Utilised flake & 2 & 1.0 \\
Sub-total & 196 & \\
Barbed \& tanged arrowhead (Bronze Age) & 2 & \\
\hline Tool by-products & \multicolumn{3}{c}{} \\
\hline Axe flake & 2 & 2.6 \\
Burin spall & 14 & 17.9 \\
Microburin (proximal) & 23 & 29.5 \\
Microburin (distal) & 5 & 6.4 \\
Microburin-like & 18 & 23.1 \\
Krukowski microburin & 11 & 14.1 \\
Retouch spalls & 5 & 6.4 \\
Sub-total & 78 & \\
\hline
\end{tabular}

\begin{tabular}{lrr}
\hline Flint debitage & & \\
\hline Flakes & 2789 & 41.8 \\
Crested flake & 16 & 0.2 \\
Blades & 209 & 3.1 \\
Crested blade & 33 & 0.5 \\
Blade fragments & 75 & 1.1 \\
Bladelets & 852 & 12.8 \\
Bladelet fragments & 336 & 5.0 \\
Crested bladelet & 34 & 0.5 \\
Core tablet & 20 & 0.3 \\
Core rejuvenation flake & 5 & 0.1 \\
Flanc de nucleus & 10 & 0.1 \\
Shatter & 162 & 2.4 \\
Chips (<10 mm) & 2033 & 30.5 \\
Cores & 99 & 1.5 \\
Sub-total & 6673 & \\
\hline Non-flint lithics & & \\
Soft stone percussor & 2 & 50.0 \\
Retouchoir & 1 & 25.0 \\
Knife & 1 & 25.0 \\
Sub-total & 4 & \\
\hline TOTAL & 6851 & \\
\hline
\end{tabular}

the Wreake river bed and its tributaries to the south and the Oadby Till to the north.

There was also a significant component of opaque Wolds flint with a variable cortex of $2-5 \mathrm{~mm}$ thickness (recorded on the database as 'Wolds'). It graded from light grey (2.5YR 7/1) to white (2.5YR 8/1), but 


\section{L.P. Cooper \& W. Jarvis. MAKING \& BREAKING MICROLITHS: MIDDLE MESOLITHIC SITE, ASFORDBY, LEICS}

was often mottled. This need not be interpreted as a Mesolithic import as such flint can also occur in the till deposits of the region. A minor component was an opaque flint that graded from reddish brown (5YR 5/3) with light grey mottles (5YR 7/1) to a strong brown (7.5YR 5/6) with very pale brown mottles (10YR 8/3). It is plausible that the latter is a ferruginous stained variety of Wolds flint (recorded on the database as 'opaque').

\section{Cores}

There were 113 flint cores excavated from the Mesolithic deposit, mostly of bladelet type (Figs $10 \& 11$ ). Of these, 99 could be classified and measured. A majority of the flake cores were patinated suggesting that they were also Mesolithic (diagnostically later tool forms and debitage from sealed deposits of Bronze Age date were not patinated). Where better quality nodules have been worked successfully the cores fall into two principal types, single or opposed platforms (Table 3). Core front preparation was common with overhangs removed by downward abrasion of the core platform edge. For bladelet cores, $84 \%$ were prepared while, for mixed cores, $64 \%$ were prepared and for flake cores only $41 \%$. Platform rejuvenation was by means of core tablet removal, usually removing the entire exhausted platform. Single platform cores were usually of prismatic shape, often with the back remaining cortical. Bladelet removal was systematic with sequential removals around the arc of the core front with progression to the flanks. Bladelet scars suggest that most removals travelled much of the way down the core front ending with feathered termination. The cores with opposed platforms demonstrate similar characteristics to single platform examples. However, the bladelets were removed in alternate suites. Platform angles were markedly acute, up to $45^{\circ}$, often presenting a wedgeshaped core when viewed from the side. Cores with opposed platforms were generally prismatic reflecting the successful removal of bladelets with a straight longitudinal profile, the ideal for microlith production. The average optimal length for all cores was $37.8 \mathrm{~mm}$ (SD $11.9 \mathrm{~mm}$ ); while bladelet cores (flake \& mixed cores excepted) the average was $37.4 \mathrm{~mm}$ (SD $8.2 \mathrm{~mm})$. The largest core with an optimal length of $88 \mathrm{~mm}$ may give some indication of the maximum length of available nodule.

The Asfordby cores compare well with the Honey Hill site assemblage which contained 231 cores, just
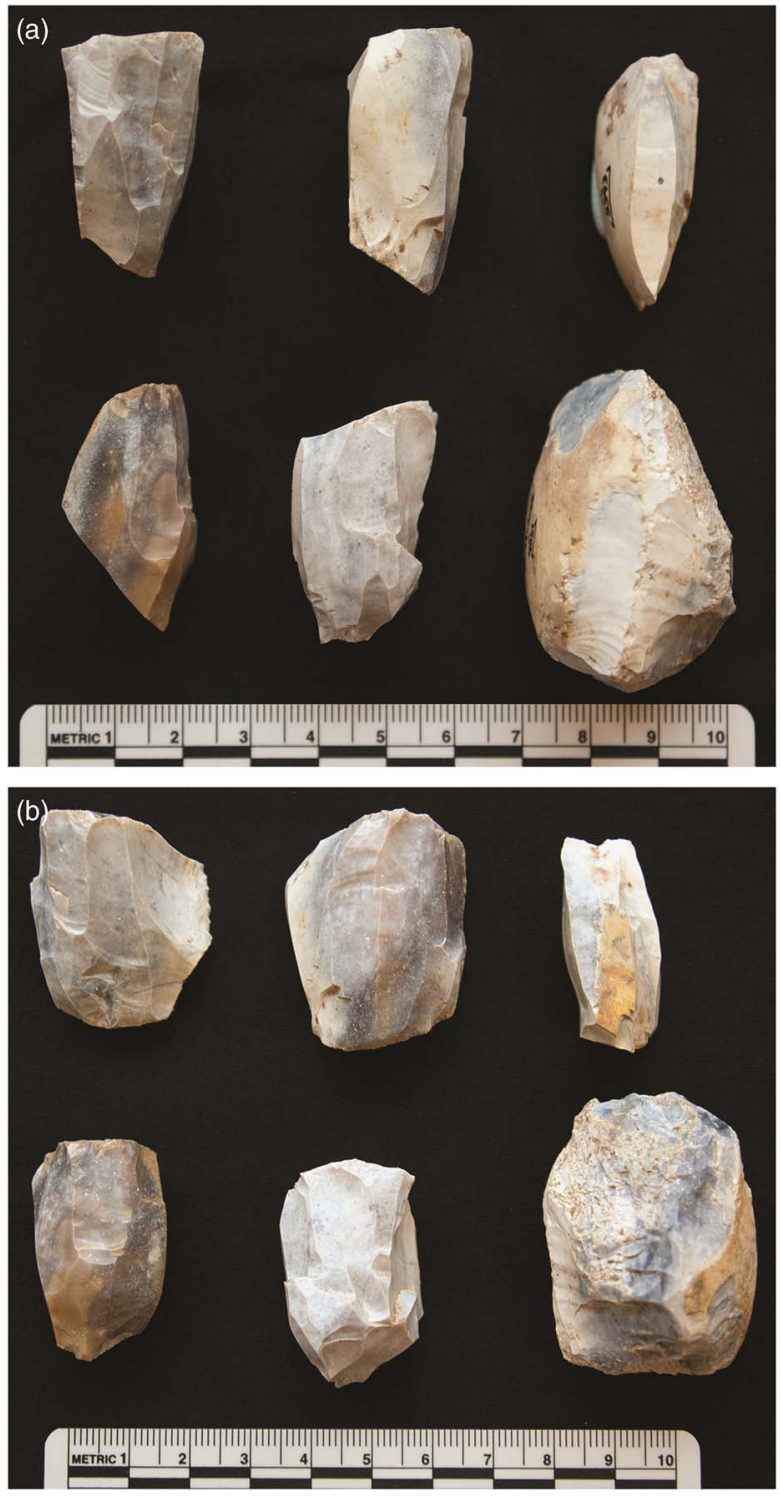

Fig. 10.

Selection of cores, (a) side and (b) front views. NB the lower right core has been re-used as a percussor

over half of which were of opposed platform type ('bipolar' in Saville 1981a). The other major class of core was of single platform type. Some reported $70 \%$ had retained cortex (ibid.), presumably much of which was in the form of unworked backs. Core size ranges suggest that most were of $40-49.9 \mathrm{~mm}$ size $(36.4 \%)$, followed by the range $30-39.9 \mathrm{~mm}(32.9 \%)$.

There is some similarity to the Deepcar core reduction methods but divergence from the core technology observed in Horsham assemblages, ie, an 
TABLE 3: CLASSIFICATION OF CORES

\begin{tabular}{llr}
\hline Type and platform class & Shape & No. \\
\hline Blade/bladelet & & \\
Opposed platform & Prismatic & 27 \\
Opposed platform & Irregular & 22 \\
Single platform & Prismatic & 1 \\
Single platform & Irregular & 11 \\
Multi-platform & Irregular & 1 \\
Multi-platform & Crossed & \\
Mixed flake/bladelet & & 5 \\
Opposed platform & Prismatic & 2 \\
Opposed platform & Irregular \\
Single platform & Prismatic & 8 \\
Single platform & Irregular & 2 \\
Multi-platform & Irregular & 2 \\
Flake & & \\
Opposed platform & Irregular & 3 \\
Single platform & Prismatic & 1 \\
Single platform & Irregular & 3 \\
Multi-platform & Irregular & 9 \\
\hline
\end{tabular}

absence of the helical turning of the core for orthogonal removals followed by removals from the core back late in the core reduction sequence (Reynier 2005). While there is some evidence for occasional orthogonal removals there are no examples of the core backs being utilised. The relative abundance of natural flint at the Asfordby locale may have meant that such an optimising strategy was not necessary, but may also be a result of genuinely different technological systems.

Some of the less regular cores may be a result of using poorer quality raw material but several may indicate differing level of skills among those working flint at the site. One example of a Wolds flint core (3318) is illustrated by photograph (Fig. 11). The core had been worked down such that no cortical areas remain. There are two orthogonal platforms that are sequential: the earliest shows multiple failed attempts to flake a platform at c. $90^{\circ}$, the resulting edge best described as battered. The final platform has large flake removals followed by multiple, stacked hinge terminations indicated repeated attempts to initiate a removal. The core appears to have been worked, at least in the final stages, by a novice, most probably a young child.

\section{Debitage}

A breakdown of the assemblage is given in Table 2 while qualitative attributes of a sample of the debitage is given in Table 4. The range of debitage material includes

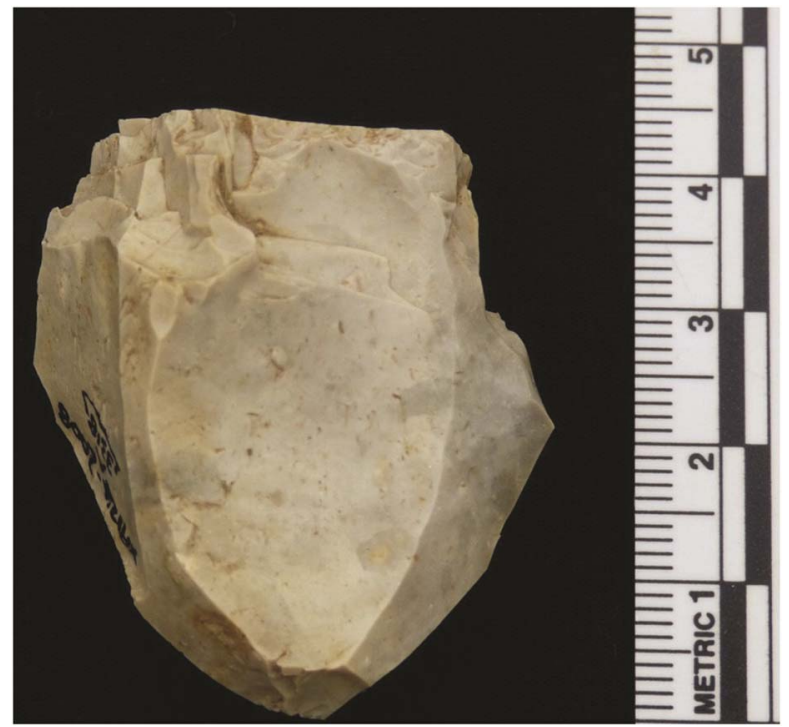

Fig. 11.

Core on Wolds flint presenting evidence for poor knapping standard in the final removals

flakes, blades, bladelets, shatter and chips. The abundant fragments were mostly the result of bladelet breakage as knapping accidents or due to trampling during site occupation. Numerous flakes, often with complete or substantial cortex cover, indicate the primary working of local flint nodules. There is evidence for both hard and soft stone percussion with some indications of core front preparation in the form of abraded margins. Such flakes could be used for the production of larger tools such as the scrapers. However, the production of small tertiary blades and bladelets was the main knapping objective. Typically these are straight in longitudinal profile, with trapezoidal cross-sections, generally having feathered terminations. The blades and bladelets ranged in length from $11-74 \mathrm{~mm}$, average length $29.6 \mathrm{~mm}(\mathrm{SD}=11.7)$. The bladelets alone had a range of $11-57 \mathrm{~mm}$, average $23.3 \mathrm{~mm}(\mathrm{SD}=9.4)$. The dorsal scars of blades and bladelets are predominantly unidirectional but opposed scars are not uncommon. Soft stone percussion is evident from ventral bulb stigmata (Pelegrin 2000) with a resulting high proportion of linear and narrow plain butts. Reynier $(2005,51)$ identified soft stone percussion in the Horsham type assemblages from Kettlebury 103 (Surrey), Longmoor 1 (Hampshire), and St Catherine's Hill (Surrey). Soft stone percussion was also suggested for Deepcar assemblages (ibid., 50) and is reported from the Early Mesolithic in Ireland (Costa et al. 2001). 
L.P. Cooper \& W. Jarvis. MAKING \& BREAKING MICROLITHS: MIDDLE MESOLITHIC SITE, ASFORDBY, LEICS

TABLE 4: QUALITATIVE ATTRIBUTES OF FLAKES, BLADES, \& BLADELETS FROM ALTERNATE SQUARES OF TRANSECT 74 NORTH. BUTT TYPES INCLUDE PROXIMAL FRAGMENTS

\begin{tabular}{|c|c|c|c|c|c|c|}
\hline \multirow{2}{*}{ Attributes } & \multicolumn{2}{|c|}{ Flakes } & \multicolumn{2}{|c|}{ Blades } & \multicolumn{2}{|c|}{ Bladelets } \\
\hline & & $\%$ & & $\%$ & & $\%$ \\
\hline Butt type & $N=202$ & & $N=13$ & & $N=79$ & \\
\hline Plain & 82 & 40.6 & 5 & 38.5 & 27 & 34.2 \\
\hline Cortical & 24 & 11.9 & - & & - & \\
\hline Punctiform & 9 & 4.5 & - & & 6 & 7.6 \\
\hline Linear & 67 & 33.2 & 5 & 38.5 & 44 & 55.7 \\
\hline Faceted & 8 & 4.0 & 2 & 15.4 & - & \\
\hline Dihedral & 12 & 5.9 & 1 & 7.7 & 2 & 2.5 \\
\hline Core front abrasion & 84 & 41.6 & 13 & 100.0 & 44 & 55.7 \\
\hline Cortex & $N=169$ & & $N=10$ & & $N=55$ & \\
\hline Primary & 3 & 1.8 & - & & - & \\
\hline Secondary & 65 & 38.5 & 9 & 90.0 & 17 & 30.9 \\
\hline Tertiary & 101 & 59.8 & 1 & 10.0 & 38 & 69.1 \\
\hline Distal termination & $N=187$ & & $N=12$ & & $N=77$ & \\
\hline Feathered/blunt & 152 & 81.3 & 11 & 91.7 & 70 & 90.9 \\
\hline Hinge & 34 & 18.2 & 1 & 8.3 & 7 & 9.1 \\
\hline Plunging & 1 & 0.5 & - & & - & \\
\hline Profile & $N=150$ & & $N=8$ & & $N=53$ & \\
\hline Straight & 97 & 64.7 & 4 & 50.0 & 36 & 67.9 \\
\hline Curving & 41 & 27.3 & 3 & 37.5 & 10 & 18.9 \\
\hline Twisted & 12 & 8.0 & 1 & 12.5 & 7 & 13.2 \\
\hline Dorsal scars & $N=150$ & & $N=8$ & & $N=53$ & \\
\hline Unidirectional & 121 & 80.7 & 4 & 50.0 & 38 & 71.7 \\
\hline Opposed & 6 & 4.0 & 2 & 25.0 & 10 & 18.9 \\
\hline Crossed & 9 & 6.0 & - & & 1 & 1.9 \\
\hline Multi-directional & 3 & 2.0 & 2 & 25.0 & 1 & 1.9 \\
\hline Uncertain & 11 & 7.3 & - & & 2 & 3.8 \\
\hline
\end{tabular}

The micro-debitage, pieces $<10 \mathrm{~mm}$, mainly comprise non-diagnostic chips in terms of their position in the reduction sequence (sensu Newcomer \& Karlin 1987). This is not surprising given the debitage and core evidence for non-use of partial edge faceting of platforms and the rare use of core front trimming. Wet sieving produced copious flint dust and chips.

\section{Microliths and microburins}

Microliths are here defined as small blades and bladelets that have been modified by retouch to a pre-determined form. They are assumed to be parts of composite tools comprising organic and lithic elements. They have commonly been regarded as armatures although other uses may have occurred (Clarke 1976; Zvelebil 1994). Often the use of the microburin technique to remove the proximal bulb is a requisite for classification as a microlith, but for this report its non-use does not preclude classification as a microlith (the earliest microliths of the Late Glacial were produced without use of the microburin technique).
Various classificatory schemes have been advanced for the British Mesolithic (Clark 1934; Clark \& Rankine 1939; Jacobi 1978) while nomenclature has often been subject to slight adjustments (Saville 1981a; 1981b). For this report microliths are classified to the scheme proposed by Jacobi (1978) comprising four principal groups: broad blade, narrow blade, hollow based bladelets, and inversely retouched bladelets, with these sub-divided into 32 shapes or types. While a majority of the Asfordby microliths are classified to type there is slight divergence from the Jacobi typology in terms of description: this is discussed where it occurs. The majority of microliths, complete and larger fragments, and a selection of microburins are illustrated (Figs 12-17). They are grouped by type and labelled with their finds number to allow concordance with the descriptions and the detailed results of the microwear analysis. Summary results of the microwear analysis are also presented.

Obliquely truncated points (Fig. 12): Fifteen complete examples of obliquely truncated points occur 
THE PREHISTORIC SOCIETY

Obliquely truncated

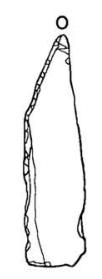

1179

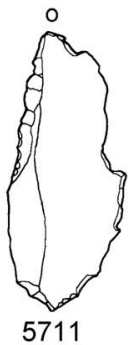

1317

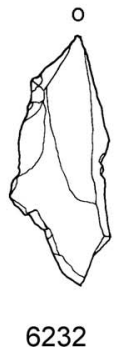

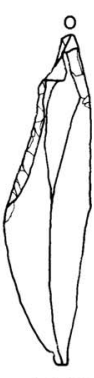

1548

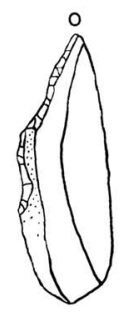

1899

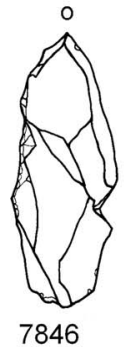

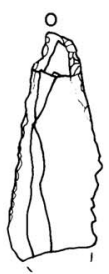
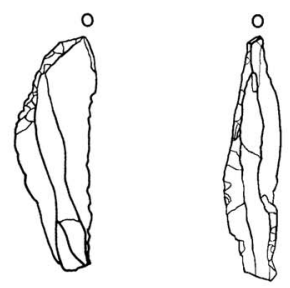

1922

2464

2811

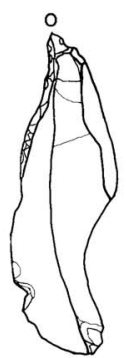

5324
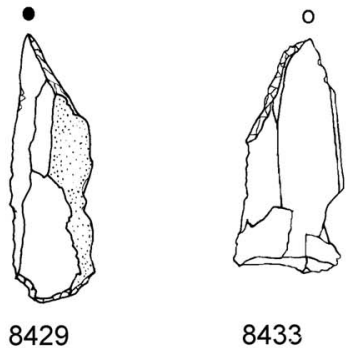

8433

Probable obliquely truncated

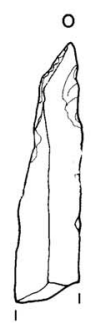

981

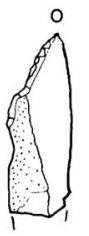

5975

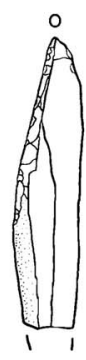

982

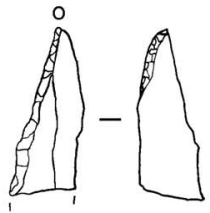

7865

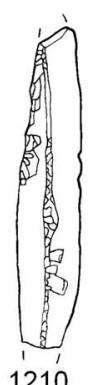

1210

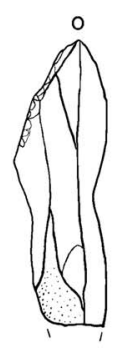

2490

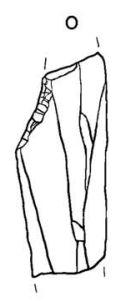

2692

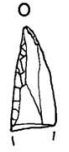

8441

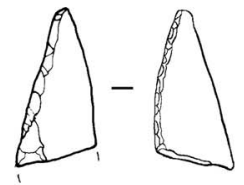

5785
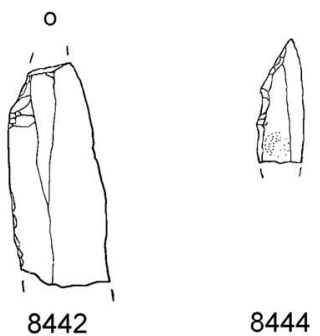

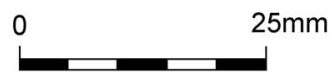

Fig. 12.

Obliquely truncated points 


\section{L.P. Cooper \& W. Jarvis. MAKING \& BREAKING MICROLITHS: MIDDLE MESOLITHIC SITE, ASFORDBY, LEICS}

including 12 of Jacobi type $1 \mathrm{a}$ and three of type $1 \mathrm{~b}$, the latter with additional or ancillary retouch at their tips. An additional 12 larger microlith proximal fragments appear to have once been oblique points, and these include three with ancillary retouch. These are termed probable obliquely truncated points (database code OTP?). Many smaller unclassified tip fragments may derive from obliquely truncated points or backed forms. All bar one display sinistral lateralisation, the dextral example being exceptional in also having a surviving bulb of percussion. Microwear analysis gave an uncertain function to the majority. This is a common observation and such pieces have been interpreted as being barbs in composite projectiles (Crombé et al. 2001) but other functions have been suggested (Dumont 1988).

Three probable obliquely truncated points display traces of use: one was used on a soft material (8437), another to cut a soft material (982) while a third was used to cut plant material (2692). Another probable example shows traces of hafting (981).

Partially backed points: There are 20 microliths of this type including nine with additional retouch on their leading edge (Fig. 13). Five examples have impact traces $(980,8439,1613,2558,5713)$ and two evidence for hafted ends $(1550,659)$. A large example was used on bone/wood (977).

Six pieces have been classified as convex backed (type 4) but some display only slight convexity (Fig. 14). A further ten convex backed pieces have additional retouch on the opposite edge, Jacobi's lanceolate forms (type 3c, proximal \& $3 \mathrm{~d}$, distal). Three microliths might be classified as type $3 \mathrm{c} / \mathrm{d}$, being lanceolate forms with additional retouch along both ends of the opposite side, two of which have continuous retouch. These three can be classed as Sauveterrian points and, if found by themselves, might be interpreted as later Mesolithic (Jacobi pers. comm.). However, although of a 'narrow blade' size range they can be compared to the smaller examples of convex backed, partially backed, lanceolate, and inverse basally retouch microliths. A fourth lanceolate type $3 \mathrm{c} / \mathrm{d}$ is somewhat wider (983): it has microwear traces for meat cutting.

There appears to be some correlation between microlith shape and function in that several backed forms (types 3c, 3d \& 4) and partially backed forms (types 1 ac \& 1bc) display impact traces $(980,1613$, 2060, 2177, 2182, 3537, 5713, 8432, 8439). These commonly have a leaf-shaped silhouette and are similar in size and shape to the more regular examples of points with inverse basal retouch. However, there are also similar pieces that have been used in butchery (lanceolates $983 \&$ \& 7058) and hide processing (lanceolate 979).

Points with inverse basal retouch: There are 14 microliths of Jacobi's inversely retouched bladelet group including nine of type 11, three microliths of type $12 \mathrm{c}$, and single examples of types $12 \mathrm{a}$ and $12 \mathrm{~b}$ (Fig. 15). The type 12 examples are what Jacobi (1978) termed straight-backed bladelets with inverse retouch (with sub-division depending on position of retouch on either lateral edge or both). Some have approximate fitting into the Jacobi typology but there is some divergence, eg, the type 11 is described as obliquely blunted bladelets with inverse retouch to a symmetrical pointed base. However, Jacobi $(1979,63)$ describes the most common form of inversely retouched pieces as the "lanceolate microlith trimmed by what is often flat and noticeably invasive flaking to a pointed or rounded tail' and a symmetrical leaf-shaped outline. There are also examples of partly backed forms rather than just ones with oblique truncations. For this study we use the general term of 'points with inverse basal retouch' to describe this group (Saville 1981a; 1981b).

Microliths in this group all display sinistral lateralisation. The most common form at Asfordby is symmetrical and leaf-shaped in outline (964, 965, $2518,3325,6531,6940)$. The basal retouching of these effectively thins the distal ends creating a bevelled base in longitudinal profile. Reynier $(1997,539)$ suggested the development of more robust archery equipment towards the end of the Preboreal as first seen in Deepcar assemblages (additional retouching and basal working of lanceolate forms). The basally modified points with inverse retouch in Honey Hill assemblages can be seen as a further development along this trajectory, as more reliable and maintainable archery equipment was needed for larger and more elusive prey (ibid.). Barton and Roberts (2008) concur with the interpretation of points with inverse basal retouch as axial armatures for arrows, suggesting that the basal modifications relate to improvements in hafting techniques, hunting requirements in the Boreal environment.

Many of the Asfordby points are broken, two of which show step-terminating bending fractures, but this can result from a number of causes. The microwear study presented conclusive evidence for impact on a single piece (970), the majority being of uncertain 
THE PREHISTORIC SOCIETY

Partially backed

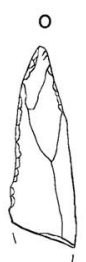

974

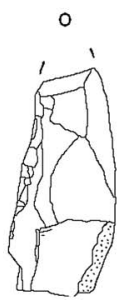

978

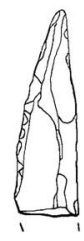

980

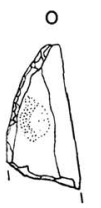

8430

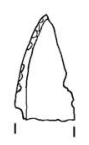

8436

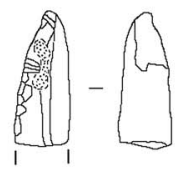

1550 (with mastic)

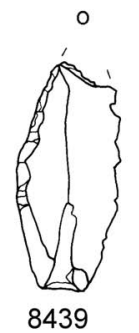

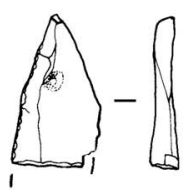

5130

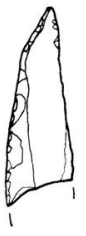

8443

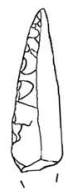

6421

Partially backed with additional retouch

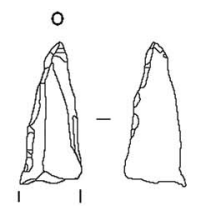

659

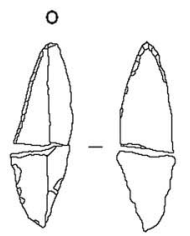

2903
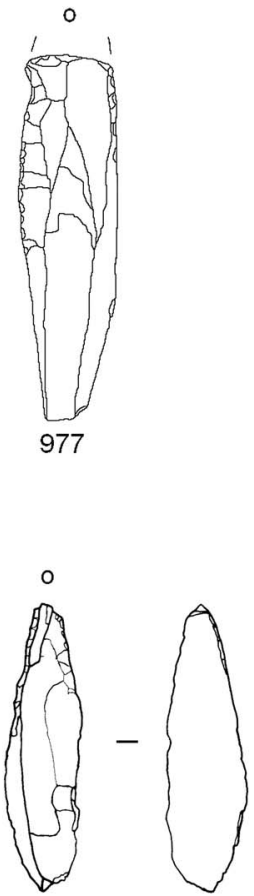

5713
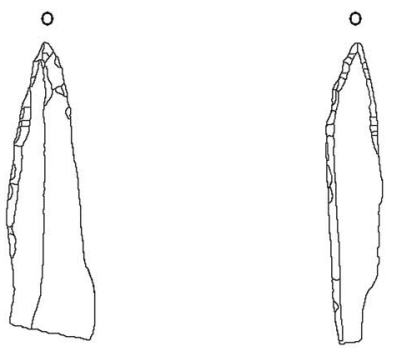

1346

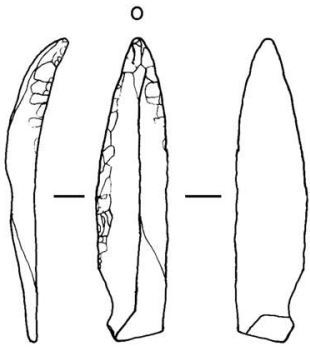

2558

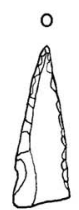

8440

Fig. 13.

Partially backed points 
Convex backed

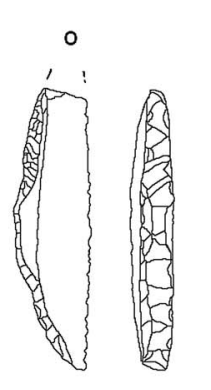

1361

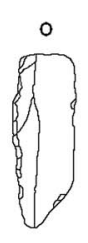

3537

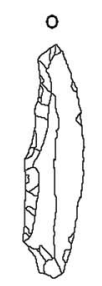

5027

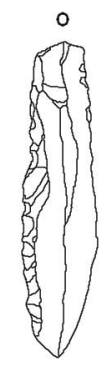

7239

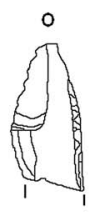

8432

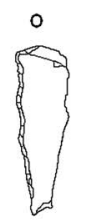

8435

\section{Lanceolate}

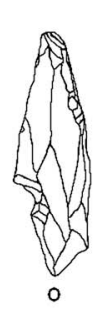

979
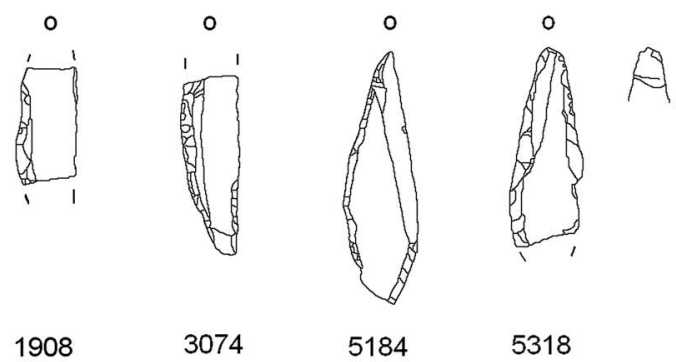

5184

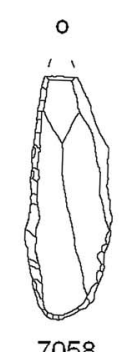

7058

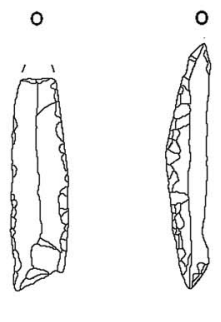

$7706 \quad 7803$

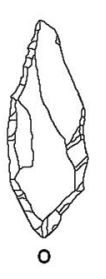

7903

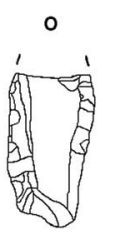

8445

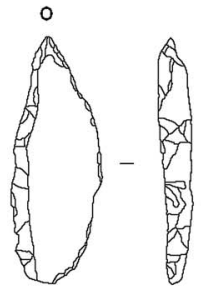

983

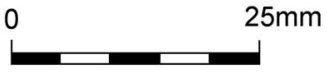

228

\section{Lanceolate (Sauveterrian points)}
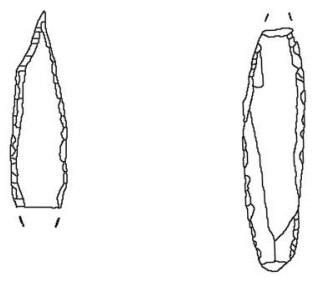

972

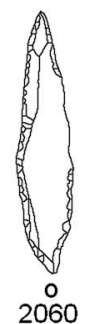

Fig. 14.

Convex backed and lanceolate points

use. Three broken examples had traces of their distal ends being hafted $(964,1648 \& 6531)$. One point (2062) has a missing tip and the resultant scar suggests its loss as a Krukowski microburin (Krukowski 1914). These pieces are thought to represent accidental damage to microlith tips during their manufacture and as such this implies the manufacture of such forms at the site. It should also be noted that the piece is unusual in not being patinated, demonstrating that other pieces lacking patina may be Mesolithic.

Geometric microliths: The geometric microliths (Fig. 16) include both broad and narrow blade varieties (Jacobi 1978). There are seven large scalene triangles with varied lateralisation. Microwear analysis presents three examples used for cutting meat (968, 971, \& 976) and one with impact traces (975). There are four, possibly five, small scalene triangles (type 7a) and seven micro-triangles (type $7 \mathrm{~b}$ ). One of the small scalene triangles produced microwear traces for impact (967), while of the micro-triangles, one was used for bone/wood working (2828) and two for piercing a soft material (2103 \& 2241). Two lunates include an example with impact traces (2177).

Geometric microlith form is often viewed as indicative of a later Mesolithic date but it is suggested 
Points with inverse basal retouch

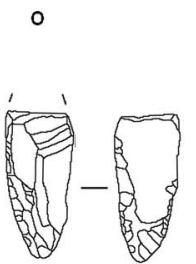

964

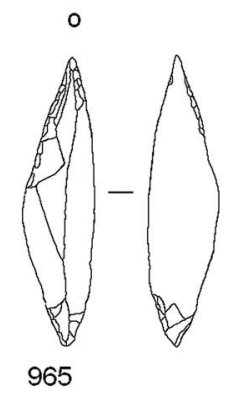

0

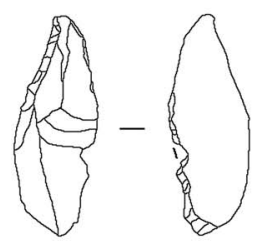

5844

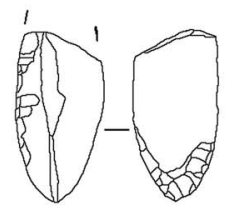

6531

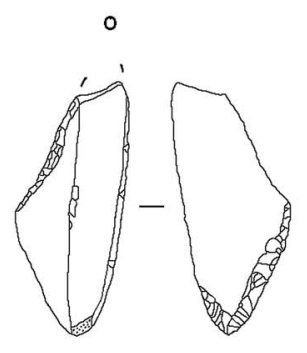

2062

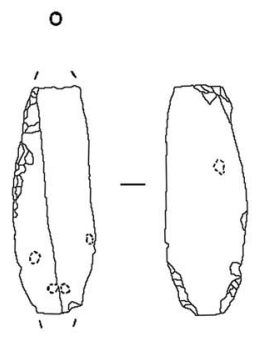

2518
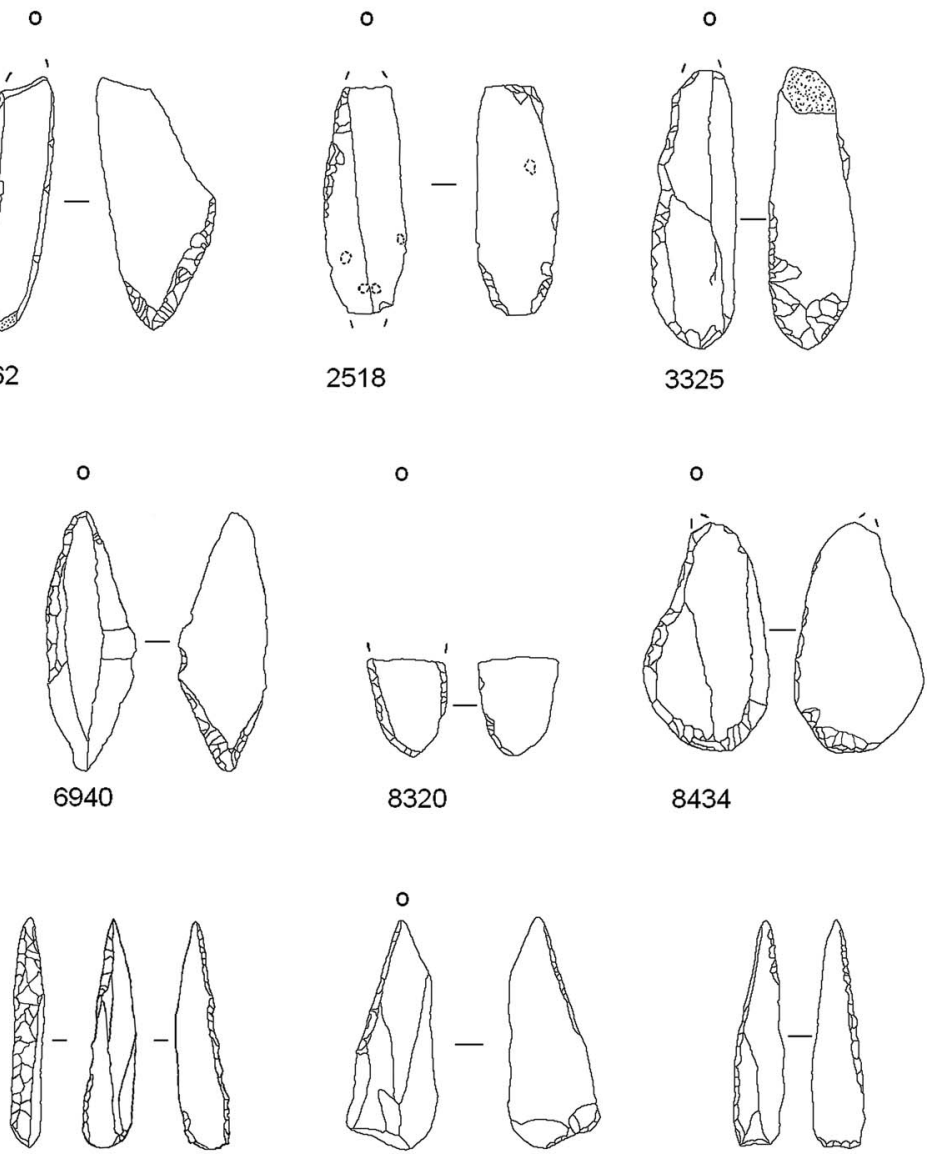

1648

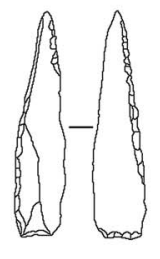

6288

Fig. 15.

Points with inverse basal retouch

(Jacobi 1978; Switsur \& Jacobi 1979) that there is a likely chronological difference with larger 'broad blade' examples being earlier than 'narrow blade' ones. Reynier $(1997,540 ; 2005)$ also drew a chronological distinction between macro- and micro-geometric forms.

Microburins: There were 23 proximal microburins, five distal microburins and 11 Krukowski microburins (Fig. 17).

\section{Other tools}

Scrapers: Fifteen scrapers were recovered all of which are illustrated (Fig. 18). The forms are quite varied with two that can be described as end-of-blade type but mostly comprising end scrapers on flake blanks. A high frequency of cortical pieces is notable suggesting that 'opening' flakes were preferred blanks. Microwear analysis demonstrates a typical relationship between scraper form and function with evidence for processing of fresh and dry hide.

Burins: Seven burins included a plain example (5567), two dihedral forms $(6606,3714)$, three examples on truncations $(3544,5061,986)$, and a Corbiac burin (5956) (Fig. 19). Only one example has traces of wear (3544) having been used to pierce hide. Evans (below) has suggested that some of the burinations may have occurred accidentally. However, this is unlikely for the burins on truncations and/or where there is sequential burinations suggesting deliberate re-sharpening.

Core tools: A possible tranchet axe/adze (4398) and a thinning flake (2783) were identified (Fig. 20). 
Rhomboids

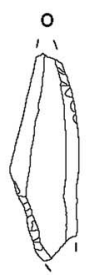

2037

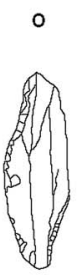

7732
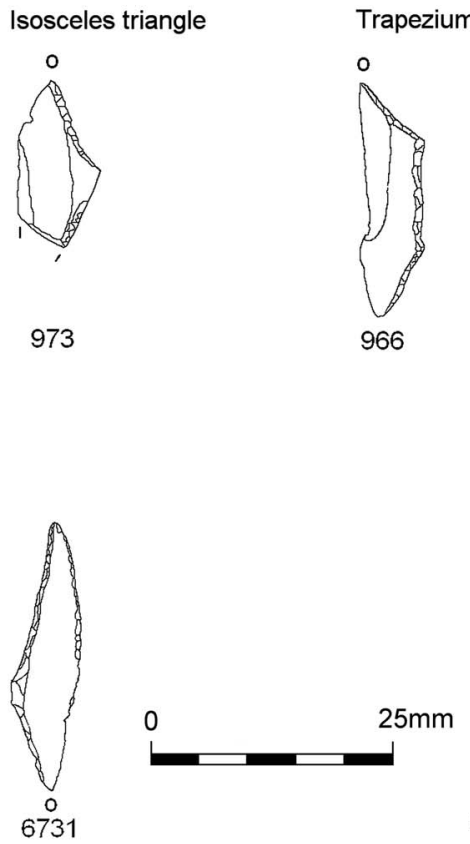

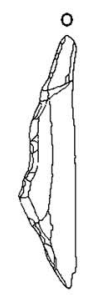

968

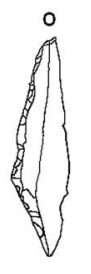

2421

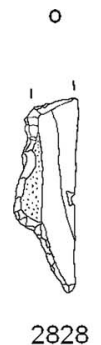

$\circ$
6359
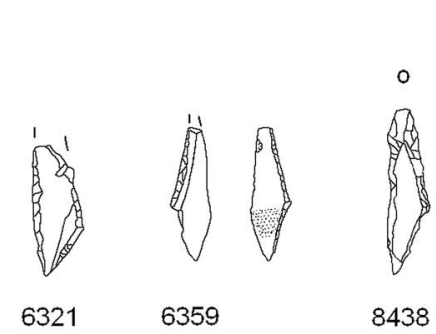

Small scalene
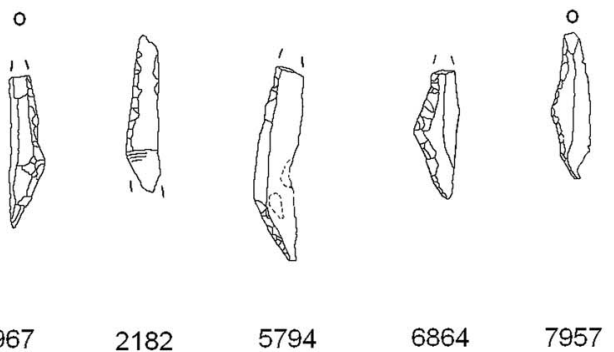

2182

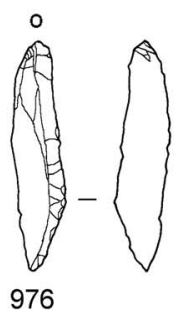

967
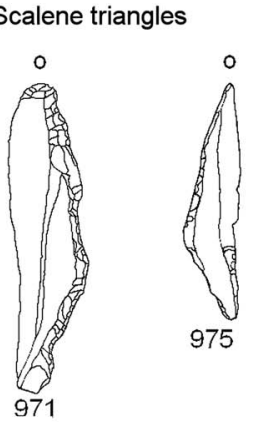

Micro-triangle

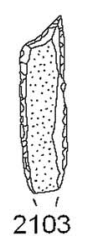

2241

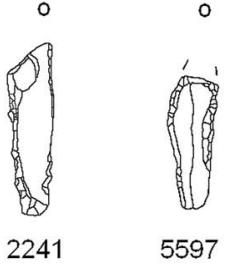

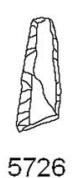

5726
Lunate

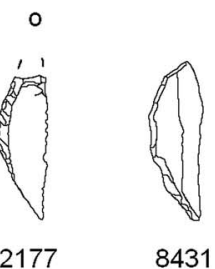

Fig. 16.

Geometric microliths

There are no traces of wear on the axe, presenting some uncertainty over its classification. The core tool 8281 presented microwear evidence for being a strike-a-light.

Flint percussors: Three flint 'cores' display evidence for prolonged percussive attrition subsequent to core removals. SF 4051 was a re-used core with opposed platforms. There are three areas with pitted scars showing heavy glancing percussive use in a single direction. Another opposed platform core (1255) has similar scars running from the core front onto one of its platforms. Flint 7113 was probably a core but extensive pitting over much of its surface precludes certain classification. Again, the pitting shows that it was used in a uni-directional, heavy, glancing percussive manner. The ridges on the flake scars, in the areas that are not pitted, show some macroscopic wear and polishing probably resulting from prolonged handling. Like the non-flint percussors this piece suggests a curated element to the toolkit. These pieces are tentatively interpreted as tools used to abrade core fronts, removing overhangs from prior removals.

\section{Non-flint artefacts}

Five fragments of skerry sandstone, two of which refit, showed clear signs of being worked. Artefact 6126/ 8398 comprised two refitting fragments that formed part of a pointed implement with clear shaping of two sides by flaking (Fig. 21a). An area of the right hand dorsal margin is extremely rounded and shows several pitted marks presumably from percussion. Given the 


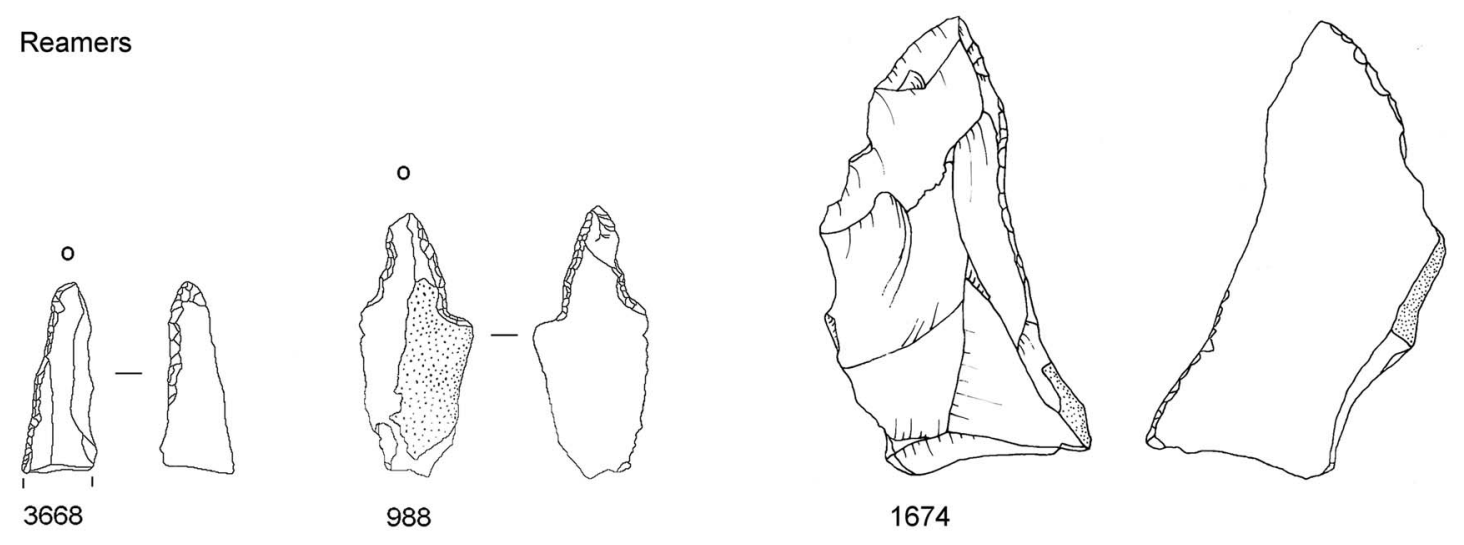

Microburins (proximal)

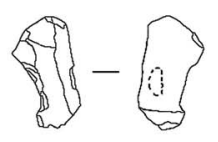

8338

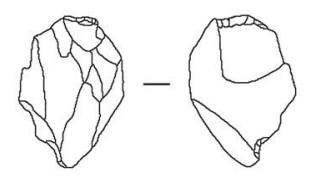

8295

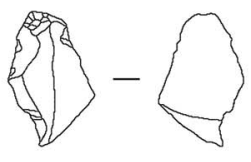

1526

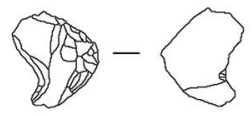

995

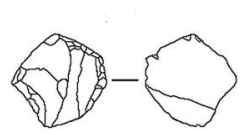

1134

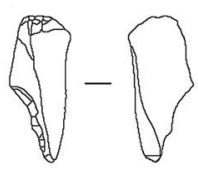

6060

Microburins (distal)

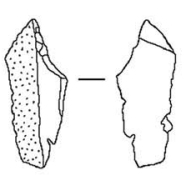

996

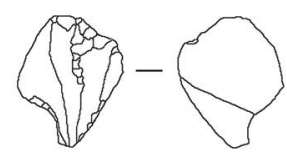

1474

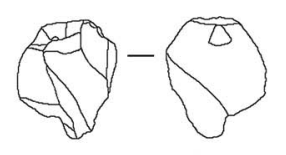

7248

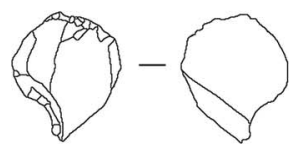

6472

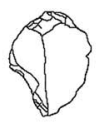

8451

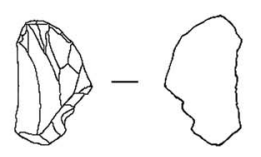

8340

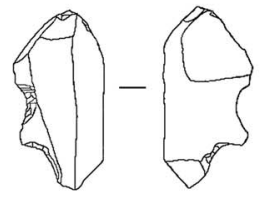

2403

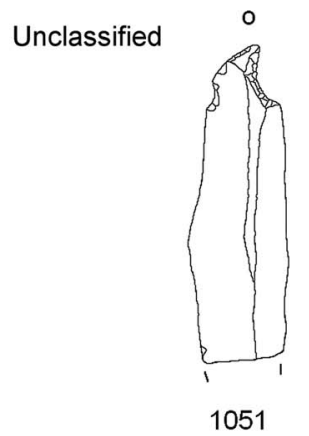

Fig. 17.

Reamers and microburins 
L.P. Cooper \& W. Jarvis. MAKING \& BREAKING MICROLITHS: MIDDLE MESOLITHIC SITE, ASFORDBY, LEICS

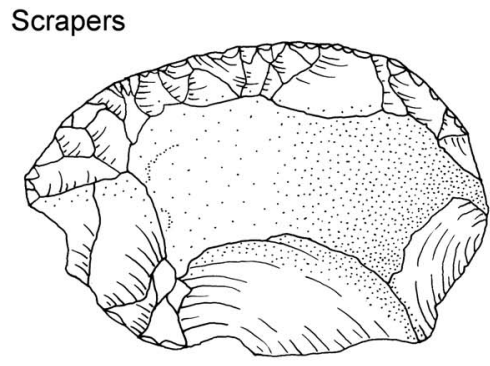

1203

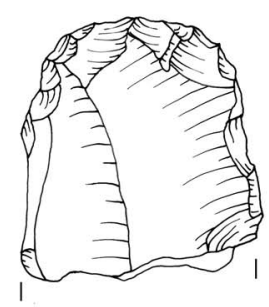

4094

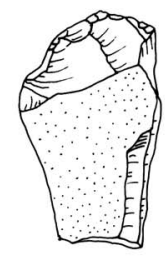

6764

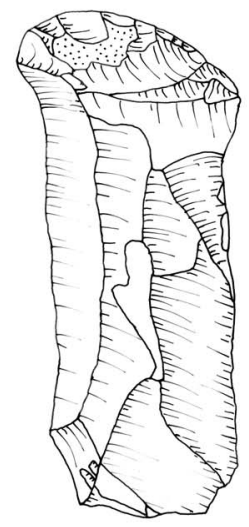

1945

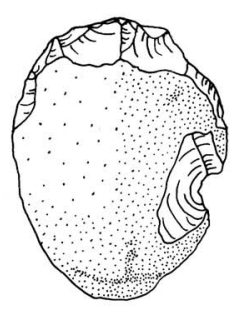

2083

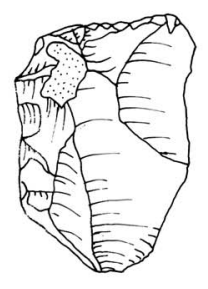

4328
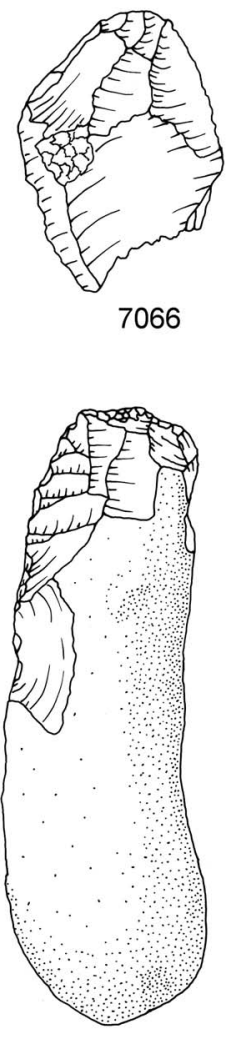

2079

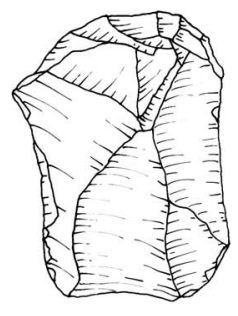

2891

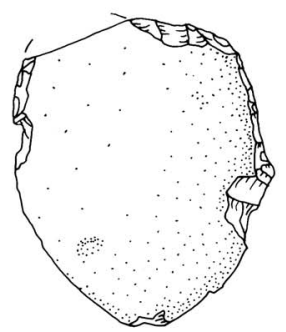

5519
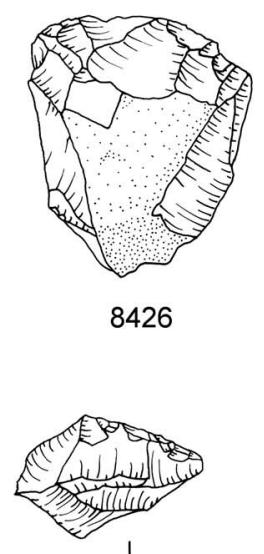

Raclette
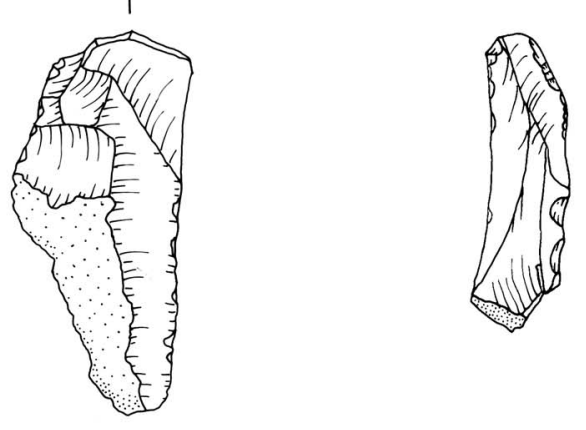

5605

Fig. 18.

Scrapers 
THE PREHISTORIC SOCIETY
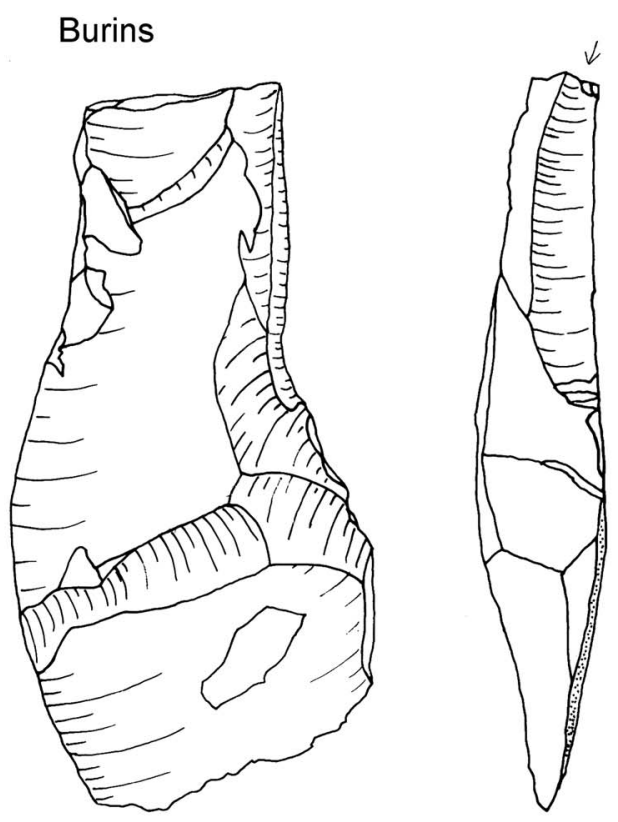

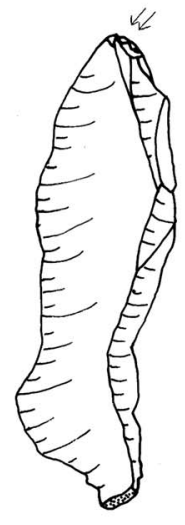

6606

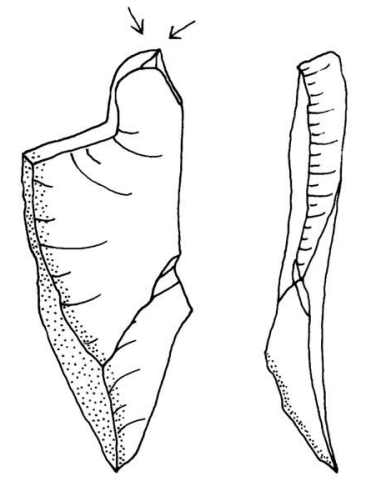

3714

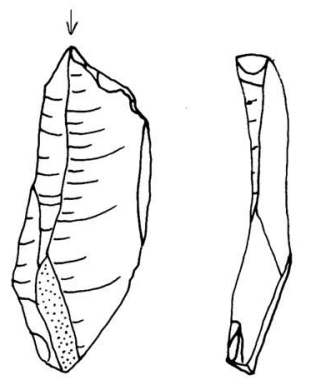

3544
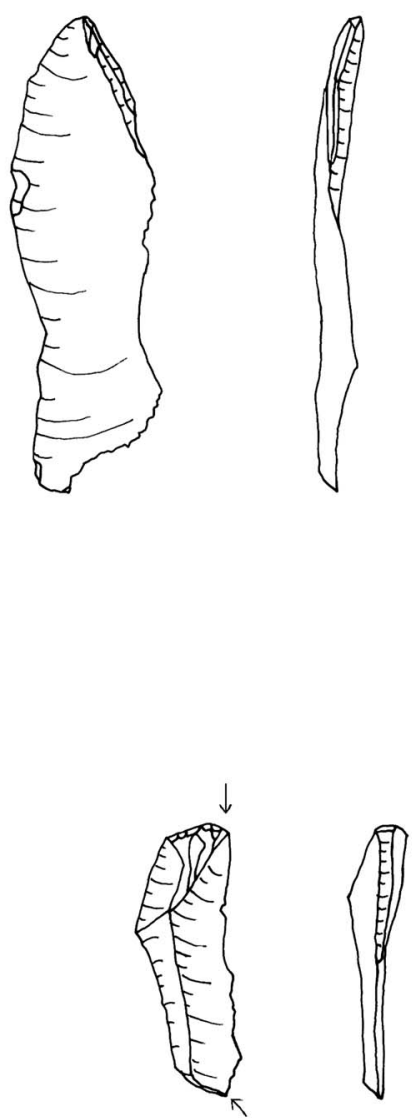

5061

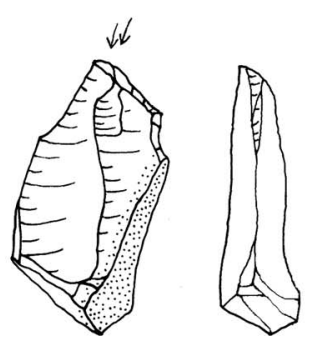

986

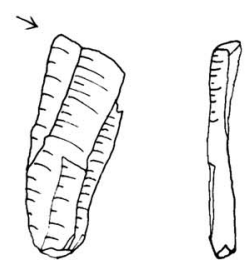

5956

Fig. 19.

Burins 
L.P. Cooper \& W. Jarvis. MAKING \& BREAKING MICROLITHS: MIDDLE MESOLITHIC SITE, ASFORDBY, LEICS

Piercer

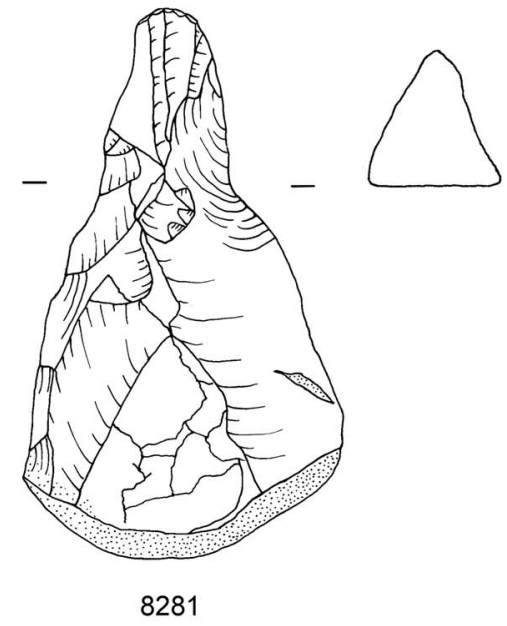

Axe thinning flake

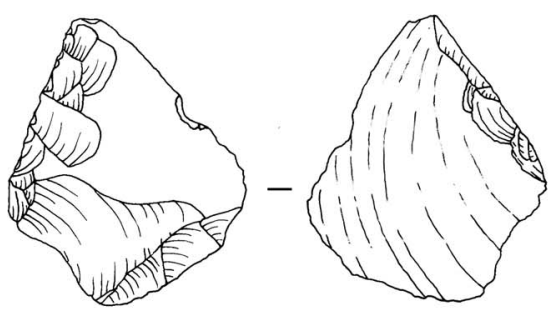

2783
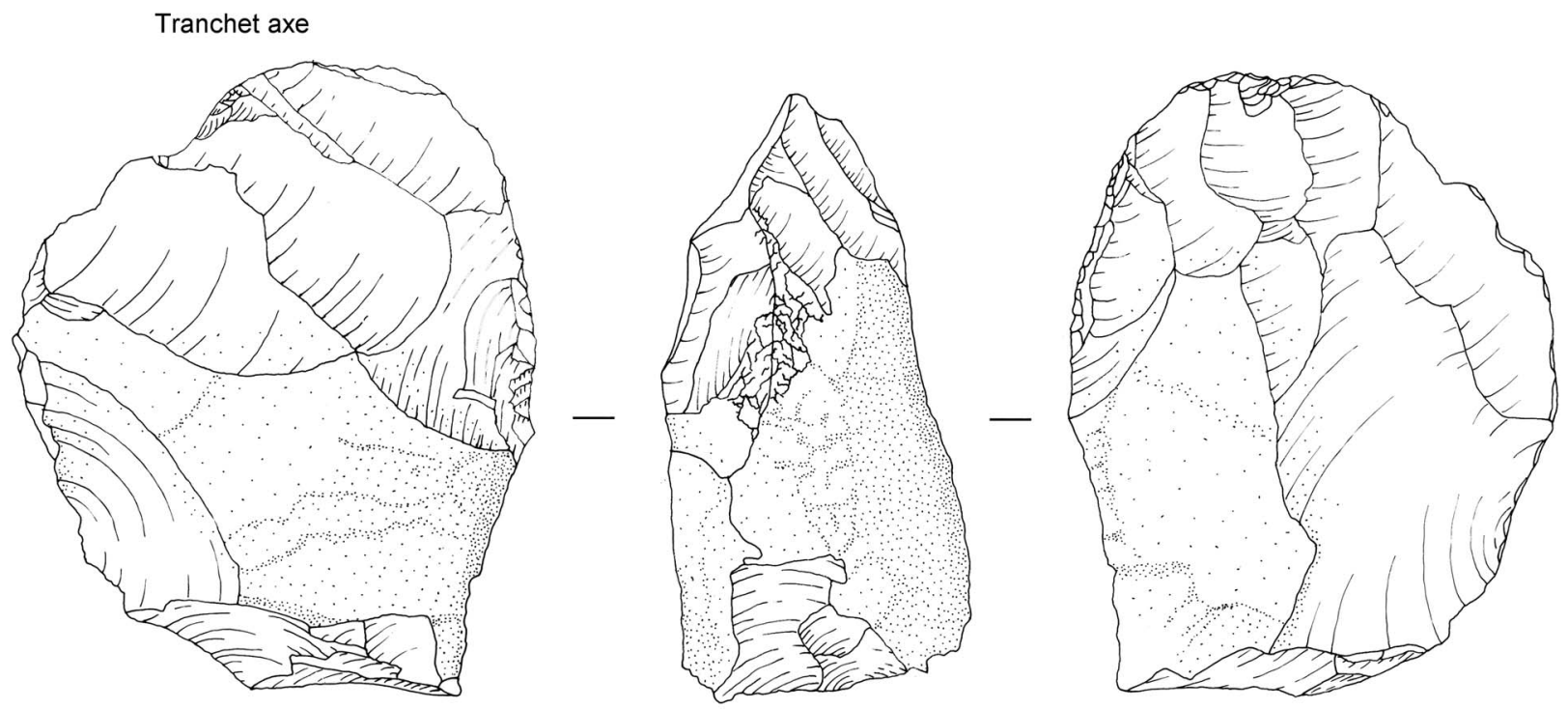

4398

Fig. 20.

Core tools

clear indications for soft stone percussion technology observed in the flint assemblage it is speculated that the artefact is part of a soft stone percussor. Its pointed shape suggests that it may have been hafted while its worn state suggests that it was a curated tool. Both fragments were recovered from the densest area of debitage in squares 28/75 and 29/75.
Artefact 8399 has one of its edges modified by steep uni-directional flaking forming a convex backed piece (Fig. 21b). It is broken at both ends. The retouched edge is convex in section possibly indicating prolonged percussive wear. The opposite side shows extreme rounding along its entire edge. Again, a percussor identification might be speculated. It was located in 

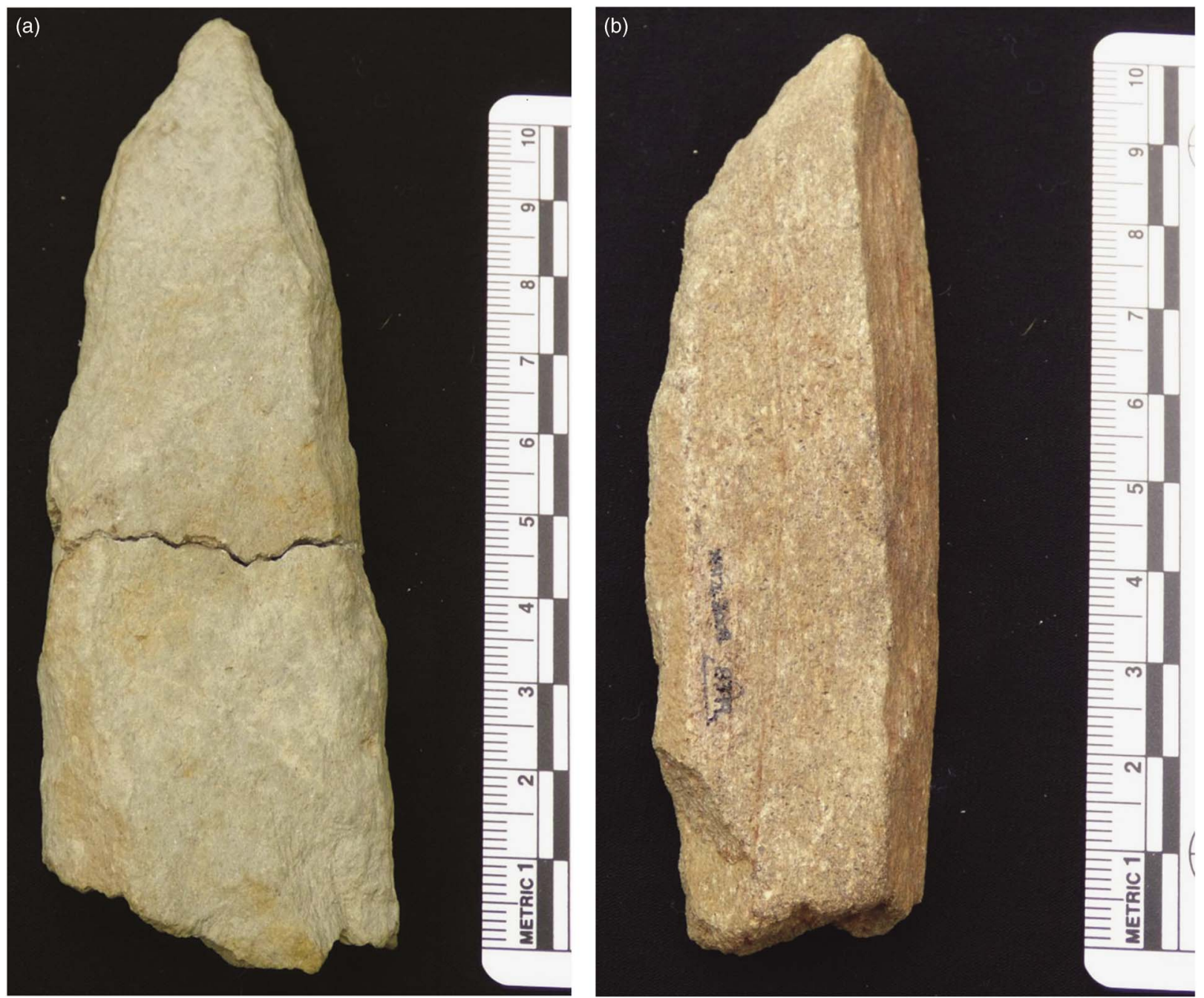

Fig. 21.

Soft stone percussors a) 6126/8398; b) 8399

square 28/74, again within the dense area of the flint scatter.

Artefact 5057 is a triangular sectioned fragment of stone with irregularly retouched lateral edges, one side showing slight rounding (Fig. 22a). The rounding is more pronounced at the corner. The piece may be a retouchoir. It was located towards the centre of the dense debitage scatter in square $29 / 75$.

A flat triangular-shaped fragment (8397) is retouched along one side (Fig. 22b). The opposite side had an acute section presenting a potential cutting edge. It is slightly rounded suggesting use. It might be described as a backed knife. It was located in square 24/71 on the southern edge of the scatter in an area with sparse debitage.

\section{Lithic microwear analysis}

(Adrian A. Evans)

Microwear analysis was undertaken on 147 lithic items at the Lithic Microwear Research Laboratory at the University of Bradford. The inspection and description of the pieces at both macroscopic and microscopic scales aimed to test the following hypotheses for each piece: 1) The null hypothesis and default position prior to this type of analysis is that the pieces are unused; 2) alternative hypotheses that may 


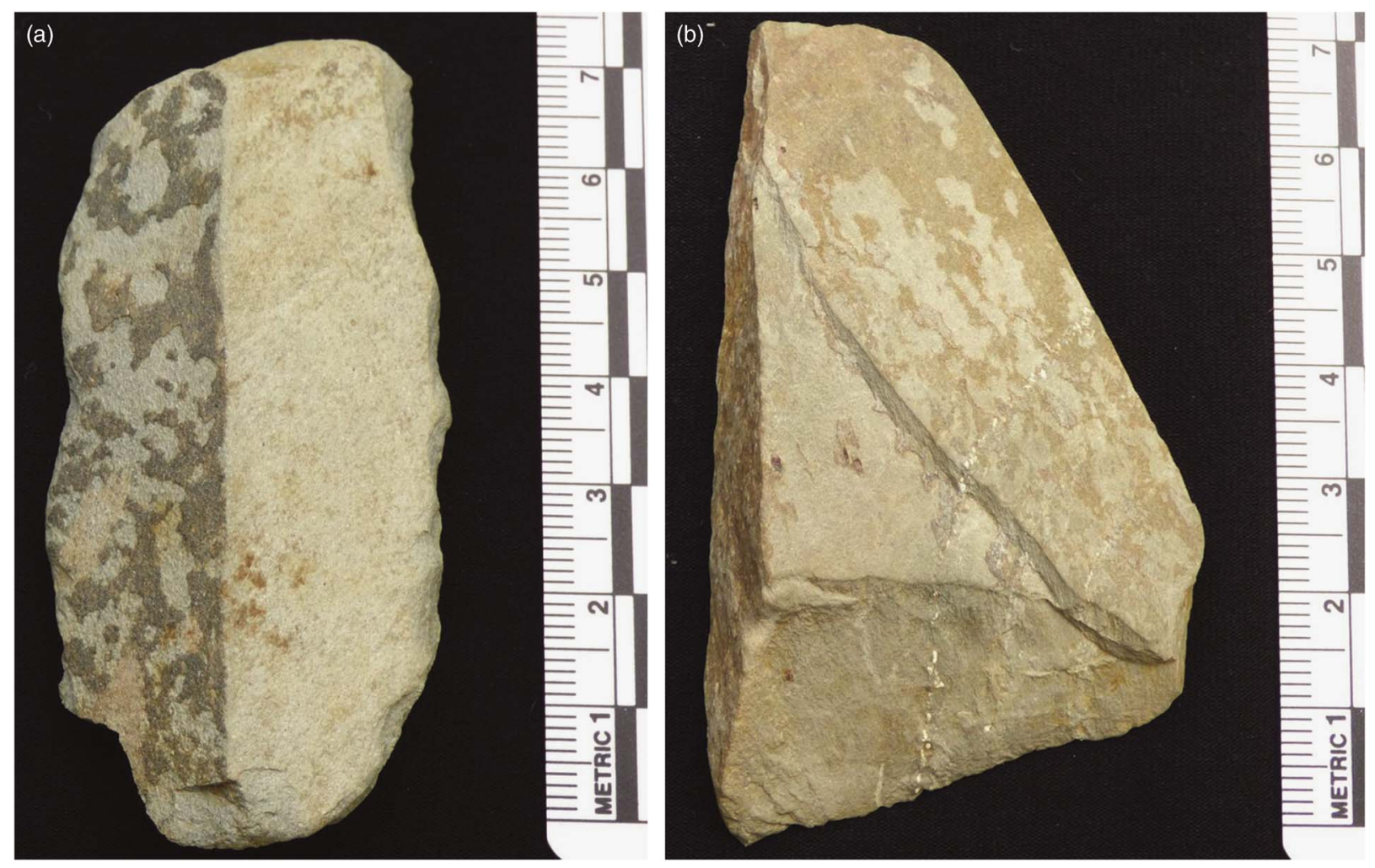

Fig. 22.

a) retouchoir 5057; b) ?backed knife 8357

vary depending on presented findings and generally related to interpreted tool uses.

\section{METHODS, SAMPLING, PROTOCOL \& RECORDING}

Microscopic analysis follows the method described by Keeley (1980), Tringham et al. (1974), and modified (Donahue 1986; Donahue \& Evans 2011). Pieces were cleaned to remove surface greases using Decon $(\mathrm{R})$ and rinsed using industrial methylated spirits (IMS). In the presence of obdurate mineral sediments the pieces were treated to a $\mathrm{HCl}$ bath $(10 \%$ for 10 minutes) before a water rinse. Several pieces in this assemblage were patinated as a result of burning and burial environment interaction. Where necessary, pieces were moulded using microset ${ }^{\circledR}$ and positives were cast using araldite DBF. This enabled imaging of otherwise highly reflective areas. Images were prepared using an Olympus $\mathrm{BH} 2$ system and a uEye CMOS camera.

Ridge rounding was used to assess preservation potential of microwear traces. In this system an arbitrary limit denoting likelihood of excellent preservation is set at $4.2 \mu \mathrm{m}$. If ridge rounding is greater than this value then preservation will be compromised. If the rounding is above approximately $14 \mu \mathrm{m}$ then preservation is likely to be extremely poor. An initial evaluation carried out on a small selection of pieces showed ridge rounding to be minimal. All measurements fall below the lower cutoff value of $4.2 \mu \mathrm{m}$ (range <1-3.518: Appendix S2, Table S3) and are very close to what could be expected from freshly produced material.

The recording database contains entries entitled 'wear description' (description of observed wear features such as edge damage and surface polishing) and 'Interpretation' (interpretation of described features taking into account the nature of traces, if they are diagnostic of particular use activities, and if they are substantial enough to allow differentiation from any post-depositional traces). 'Wear code' (Donahue 1986; 1994; Evans 2009) provides codes for the interpreted material class or specific type (depending on the quality of microwear traces) and for the motion of activity. A short description of this code is also provided in each diagnostic case. The coding/classification scheme serves to allow different levels of interpretive certainty with the view to negate over interpretation of non-diagnostic traces. For example, one may revert to an interpretation of 'hard' contact material, which is a generic classification for wood, bone, or antler. If traces are suitably preserved then 
class can be recorded to a higher degree of specificity, such as 'wood'.

\section{MICROSCOPIC ANALYSIS RESULTS}

A use-interpretation could be made on 62 of the 147 pieces ( $42 \%$; generally wear analysis yields $\sim 30 \%$ success). This high figure is attributed to the quality of the assemblage as a whole and good use of preliminary wear data in the selection of contexts to study. Nine pieces were unused. Two were not studied due to substantial residues. Thirty pieces were burned to a point where analysis was not feasible.

\section{WEAR ANALYSIS RESULTS}

\section{Microlith forms}

One hundred and seven microliths were studied. Four were found to be unused and 68 had wear that was not considered suitable for interpretation. Sixteen pieces had impact damage traces. This is usually associated with projectile use and represents $15 \%$ of the studied assemblage. Experimental studies have shown that 'diagnostic' impact traces occur on approximately $30 \%$ of projectile assemblages. The low figure here could be an indicator that projectile use is not a dominant function of these pieces. Fifteen further microliths have been used for a range of tasks including eight microliths used for butchery or hide preparation activities (Table 5). Ten microliths are suggested as representing the hafted end of a broken tool. The results are listed in Appendix S2.

\section{Other tool forms}

The 15 studied scrapers yielded eight examples with userelated wear (Table 6; Fig. S1). All uses are related to hide working with differences in the wear allowing some differentiation between working fresh (3 examples) or dry (4) hide. This can be a useful differentiation when discussing seasonality. One scraper was used to work hide but its state could not be determined. Only one burin of eight examined yielded wear traces and this was associated with hide cutting. Some of the burinated pieces are likely accidentally formed and were not designed for activities usually associated with such tools.

The study has yielded a good return of positive results that is testament to the good preservation of material. The small size of the overall assemblage, however, compromises the strength of interpretations that can be made as a result.

The results show a wide range of tool uses notably diversity in the function of microliths (Table 5).

TABLE 5: VARIETY OF DIFFERENT CONTACT MATERIALS WORKED USING MICROLITHS

\begin{tabular}{lcccccccc}
\hline Microliths & Bonelwood & Hide & Impact & Meat & Plant & Soft & Unused & Total \\
\hline Unclassified & - & - & 1 & 1 & - & - & - & 2 \\
Backed & - & - & 3 & 2 & - & - & 1 & 6 \\
Part-backed & 1 & - & 2 & - & - & - & 1 & 4 \\
OTP & - & 1 & 4 & - & 1 & 2 & 1 & 9 \\
PIBR & - & - & 1 & - & - & - & 1 & 2 \\
Rhomboid & - & - & 1 & - & - & - & - & 1 \\
Sauvetterian & - & - & 1 & - & - & - & - & 1 \\
Scalene & 1 & - & 2 & 3 & - & 2 & - & 8 \\
Trapezoid & - & - & - & 1 & - & - & - & 1 \\
Crescent & - & - & 1 & - & - & - & - & 1 \\
Total & 2 & 1 & 16 & 7 & 1 & 4 & 4 & 35 \\
\hline
\end{tabular}

TABLE 6: CONTACT MATERIAL CLASSES FOR EACH OF THE NON-MICROLITHIC TOOL FORMS

\begin{tabular}{|c|c|c|c|c|c|c|c|c|c|}
\hline Tool Type & Bonelwood & Dry bide & Fresh hide & Hide & Meat & Strike & Wood & Unused & Total \\
\hline Axe & - & - & - & & - & - & - & 1 & 1 \\
\hline Burin & - & - & - & 1 & - & - & - & 3 & 4 \\
\hline Pick & - & - & - & - & - & 1 & - & - & 1 \\
\hline Retouched & - & - & - & - & - & - & 1 & - & 1 \\
\hline Scraper & - & 4 & 3 & 1 & - & - & - & 1 & 9 \\
\hline Utilised & - & - & - & - & 1 & - & - & - & 1 \\
\hline Flake & - & 1 & - & - & 1 & - & - & - & 2 \\
\hline Bladelet & 1 & - & - & - & - & - & - & - & 1 \\
\hline Total & 1 & 5 & 3 & 2 & 2 & 1 & 1 & 5 & 20 \\
\hline
\end{tabular}




\section{L.P. Cooper \& W. Jarvis. MAKING \& BREAKING MICROLITHS: MIDDLE MESOLITHIC SITE, ASFORDBY, LEICS}

While projectile function appears dominant, a wider range of uses includes the cutting of hide and meat (butchery type activities), the working of bone or wood as part of craft activities, and the cutting of other materials including plant material (not to be confused with sickle gloss). The data presented here add further support to the argument that microliths were used to carry out a broad range of tasks (eg, Evans 2009; Evans \& Donahue 2012). Some 9\% of the microliths studied showed evidence of broken hafting. This is a higher ratio than observed in other studies of large microlith assemblages (Evans 2009; Evans \& Donahue 2012) and suggests that retooling activities occurred at the site.

The evidence for several types of dry hide working (cutting, piercing, and scraping) is an indicator of a residential site. These are activities that are usually carried out close to living spaces rather than at hunting stands or short-term camps. Binford (1980) noted that, in general, there is a predominance of maintenance activities at residential bases. Along with hide processing activities the presence of broken and impact-damaged microliths can be taken as evidence of retooling. These are all lines of evidence in support of this being a residential location. However the ratio of microliths to scrapers is such that making a strong suggestion of site type is hard. It could be a resource procurement location where retooling was taking place and a small amount of other incidental activities occurred. The fresh hide scraping and butchery are activities that can occur at locations where animals have been hunted. Carcases are often prepared at the hunting stand before returning to residential bases. Given the small size of the assemblage the tendency here is to support this location as a resource procurement site.

Variations in certain activities can primarily relate to seasonal variations in activities. The observation of hide processing activities and the manufacture of projectiles at the B\&Q Mesolithic site, Southwark was interpreted as indicating autumn or winter occupation (Donahue 2002, 87). As the same pattern has been observed at Asfordby then the same interpretation is proposed here, that the site was likely occupied during the autumn or winter.

The data presented, and the analysis and discussion show that the findings of the preliminary analysis were correct as the assemblage has generated a good amount of use-wear data. This lends further support to the use of ridge rounding analysis as a proxy for post-depositional modification of microwear traces. The use of moulding and replica casting has proved highly useful in the analysis of patinated pieces. Though this did not resolve issues for the analysis of badly burned pieces it did allow the analysis of pieces that had been burned and were otherwise chemically patinated. The assemblage presented for analysis was small and this has limited interpretative capabilities. However, the data provide good indications that a wide range of maintenance activities were occurring at this location with hide processing and retooling of impact-damaged microliths being principal activities. The presence of meat cutting is a further indication of residential activities as food processing is considered a task that occurs at a home base. The number of microliths with impact damage is taken as an indicator of the use of lithics for hunting and therefore resource procurement and the dominance of this tool type in the assemblage compared to the relative low ratio of scraping tools is also supportive of the site as a resource procurement location.

\section{Residue on microlith 1550}

(Rhea Brettell \& Carl Heron)

A microlith was associated with an apparent organic residue and this was subject to analysis by combined gas chromatography-mass spectrometry. The results were inconclusive. A full report is presented in Appendix S3.

\section{FAUNAL REMAINS \\ (Jennifer Browning)}

Animal bone was identified and hand-recovered on site. Bulk samples taken routinely were wet-sieved and also sorted for bone. Assessment work identified that while $50 \%$ of fragments were hand-recovered, this comprised $80 \%$ of the assemblage by weight. All 417 targeted residues were sorted for bone during the analysis stage with a catalogue of the amount of bone and any identifiable pieces being recorded. The material consisted largely of non-diagnostic small fragments $(<2 \mathrm{~mm})$. The vast majority of material $(98 \%)$ was calcined. No butchery marks were observed. Some variation in bone size was observed, so both large and medium sized mammals were possibly represented. However, only three bones could be identified, two being phalanges, one from the Cervidae family (deer) and one of the pig genus Sus. 
The third is possibly a metatarsal, again from a deer or another small ungulate (A. Gouldwell pers. comm.) which showed signs of being worked. The latter fragment was not calcined (16 mm long) and comes from the (?) distal end of the shaft with part of the epiphyseal surface preserved. Two longitudinal facets have been removed; one on each side and are polished. The preserved surface between the facets appears heavily eroded. There was no evidence for the presence of small mammals, birds or fish.

\section{SPATIAL ANALYSIS}

(Lynden P. Cooper \& Matthew G. Beamish) The hand-recovered lithics and calcined bone were recorded on site with a Global Positioning System with spatial data transferred to the site database. Statistical assessment of the dated bone and lithic microlith classes suggested that the Mesolithic occupation deposits did not preserve a vertical temporal sequence. Therefore the plots conflate the data from all of the excavated spits on the assumption that some $\mathrm{x} / \mathrm{y}$ spatial integrity might be observed. Lithic types were recorded in a multi-table custom relational database (Access 2010). The analysis results were joined in a single table form and exported to a File geodatabase linked with a GIS project using ArcGIS 10.1.

The exported table was filtered using SQL in the GIS project to generate finds category layers using the coordinate data recorded during the excavation of the site to spatially represent the finds. These layers were saved as separate point shape files within the geodatabase.

In order to produce contour plots of the distributions of various categories of find/attribute, the following method was used. A grid was established over the data with a cellsize of $0.25 \times 0.25 \mathrm{~m}$ (Data Management Tools, Feature Class, Create Fishnet).

The layer point shape files were counted within the grid cells to create a finds density (Spatial Analyst Tools, Density, Point Density), and saved as new shape files within the geodatabase.

The grid density shapefiles were then converted to raster points, from which were created Triangulated Irregular Networks (TINS) (3D Analyst, Tin, Create Tin). Filled contours were generated from the TINS by firstly converting to raster files (3D Analyst, Tin to Raster) from which the filled Contours could be produced (Create Filled Contours) which were then smoothed (Cartography Tools, Generalization, Smooth Polygon) using the default PAEK method (Polynomial
Approximation with Exponential Kernel) with a smoothing tolerance of $500 \mathrm{~mm}$ to create the final plots.

\section{Aims and objectives}

The sedimentological analysis and study of the lithic assemblage have suggested that the artefact scatter is in a primary context of a buried soil. The main aim of the spatial analysis is to further test this proposition for a palaeosol and to investigate the integrity of the scatter as an in situ occupation site. If such can be suggested several taphonomic objectives can be pursued. The scatter may have been formed and transformed by several processes. The cultural remains may have resulted from activity at different scales, ranging from a single visit by a group of people to multiple visits over several hundred years. A palimpsest of activity is indicated by the results of the radiocarbon dating programme. The objectives of the study are to reconcile the dating evidence of episodic visits over several hundred years with the apparent evidence for focused and defined activities hinted at in the lithic assessment (Cooper 2012) and the analysis (see Cooper above). The spatial analysis was undertaken to tackle such issues and investigate if there was any stratigraphic integrity such that there is a latent structure that might embed behavioural aspects (Binford 1983; Leroi-Gourhan 1993). With some effort such encrypted archaeological remains may be deciphered (Stapert 1989; Cooper 2006, 76).

The plot of all lithics reveals a sub-circular scatter of c. $6 \mathrm{~m}$ diameter, with a halo of artefacts of lesser density (Fig. 23). There are clear sub-clusters of microdebitage toward the centre of the scatter indicating likely areas of intensive knapping.

During the excavation and assessment phase of the project a simplistic reading of the site suggested that there was knapping activity around a hearth. Such sites are manifold in the archaeological record of the Upper Palaeolithic and Mesolithic periods. However, hearth structures such as stone settings or scorched features are often lacking and their former presence has to be inferred from clusters of burnt lithics and/or calcined bone (Sergant et al. 2006). For the radiocarbon modelling two hearths were suggested: an east hearth more or less central to the lithic scatter and a west hearth (Fig. 7). The principal east hearth was inferred from high frequencies of burnt lithics and calcined bone, and relatively high magnetic susceptibility readings. A suggested position for the inferred 


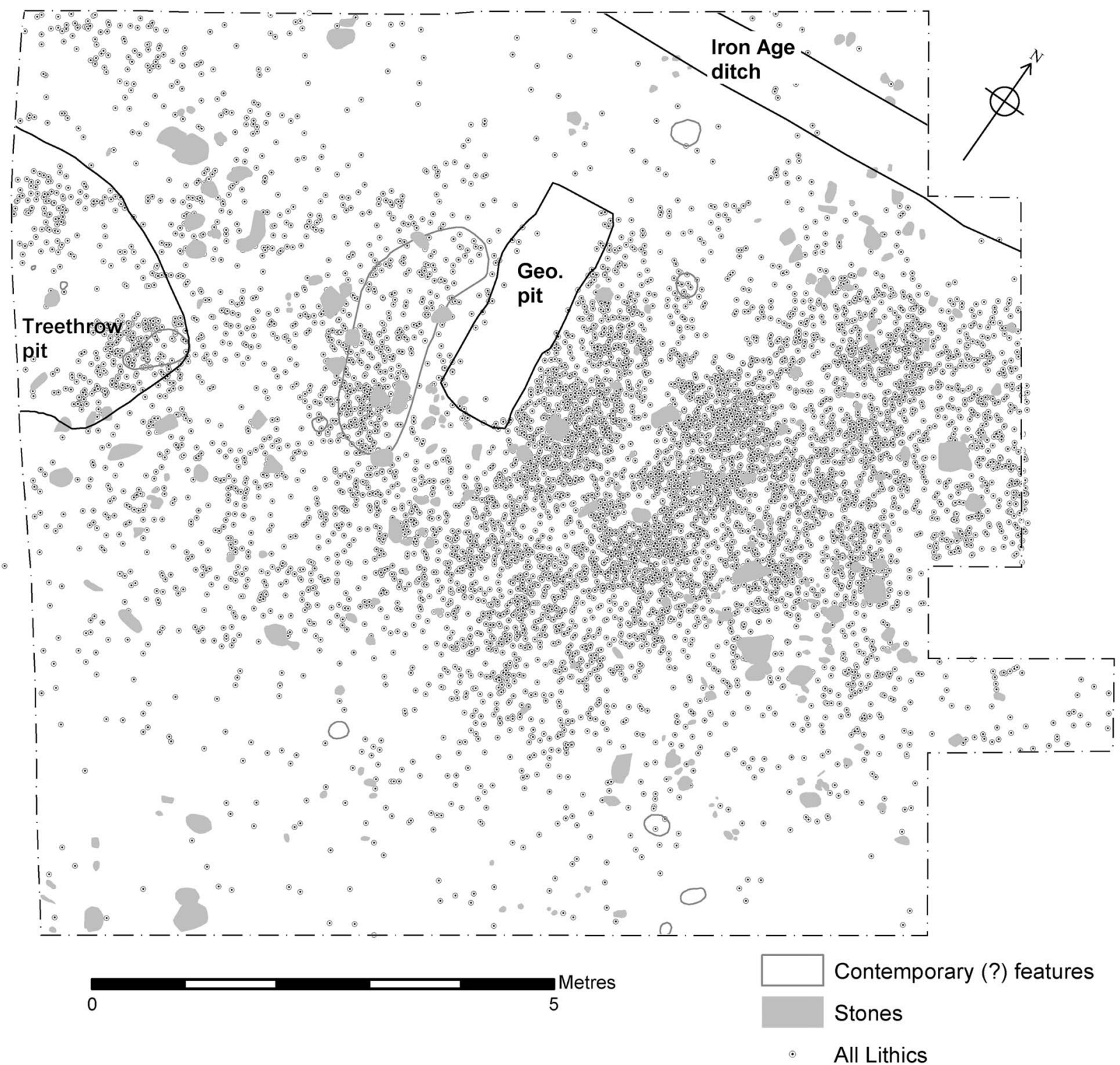

Fig. 23.

Plot of all lithics showing contemporary and later features and large unworked stones in the Mesolithic deposit

hearth is shown as a circle on Figure 24. The west hearth was inferred from a cluster of calcined bone but is much less convincing.

We investigated the possibility that the knapping scatter and east hearth may have been undertaken in a tent structure of circular or polygonal plan (Stapert 1989; Gelhausen et al. 2004). There is a certain focus to the lithic knapping debris and tool deposition around the postulated hearth zone with a sub-circular planform. A possible boundary effect of a tent may be suggested by the finds fall off to the south and north. However the scatter is spread to the west and extends beyond the excavated area to the north-east. We have suggested a possible outline for a postulated circular structure of $6 \mathrm{~m}$ diameter, with an assumption that a hearth would be a central feature. Plotting of the cores from the site, the larger components more subject to centrifugal forces, shows a clear concentration of pieces within the circle and associated with the areas of dense debitage, but no certain boundary effect is discerned (Fig. 25). Several 


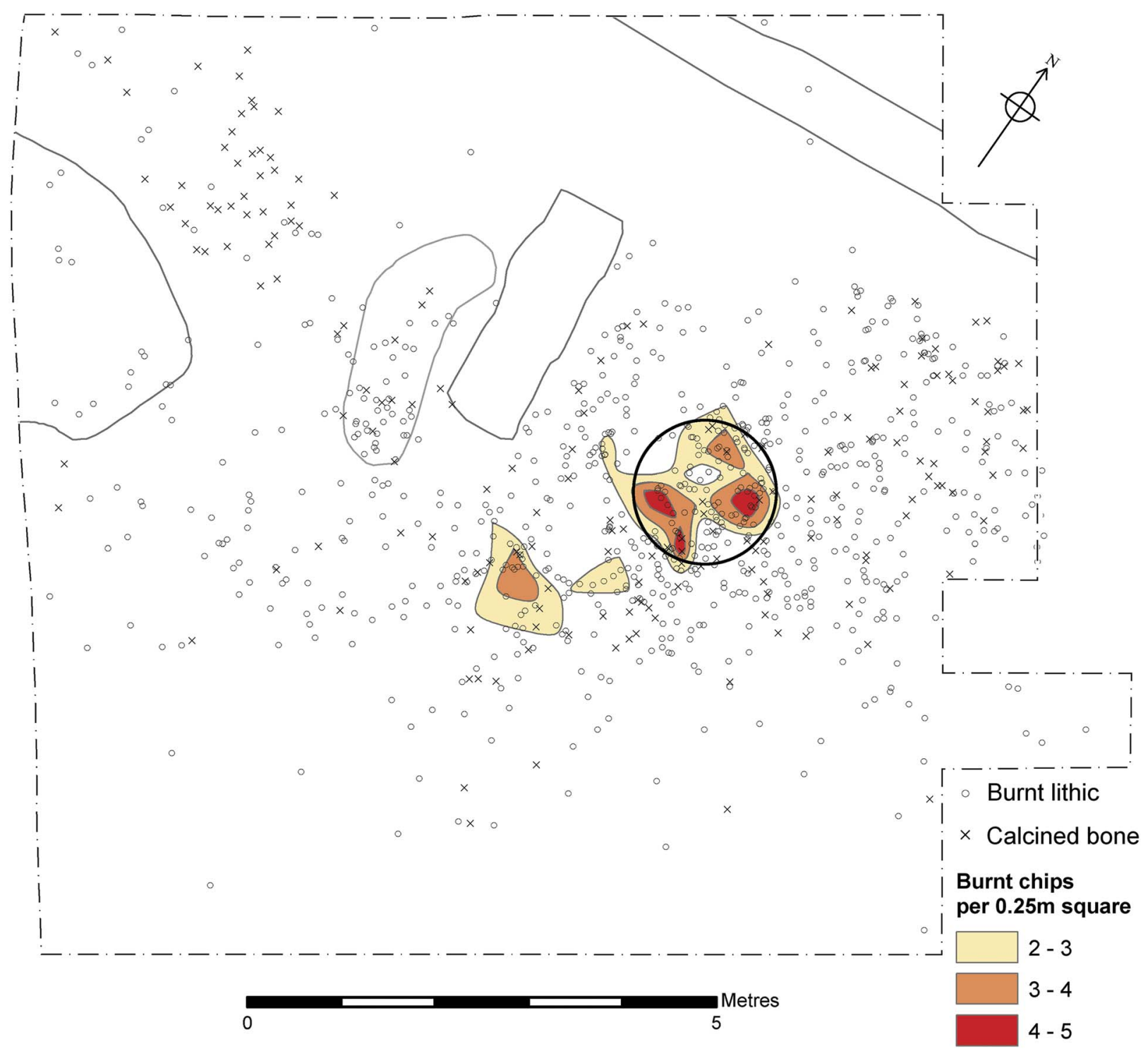

Fig. 24.

Plot of burnt lithics and bone with reconstructed hearth position (1.2 $\mathrm{m}$ diameter circle)

cores clearly lie beyond the postulated structure. However, looking at the plots of tools and tools with use traces shows the activity zones may be bounded. Five 'post-holes' were located around the edge of the postulated tent, feasibly having a structural function. The large stones around the postulated tent outline may also have served a structural function. However, the existence of a structure remains equivocal.

Microlith production, indicated by microburins (including Krukowski type), is focused to the immediate north-east and south-west sectors of the postulated hearth zone (Fig. 26). Given the evidence for many of the microliths as parts of hunting equipment it might be inferred that these were produced by a man in those areas (Johansen \& Stapert 2000; Keeley 2010). Plotting of the microliths shows a tight cluster around the hearth with the south-west sector as the most tool-rich, followed by the north-east sector. There is a noteable spread of microliths beyond the hearth zone to the west and south-west (Fig. 27).

Plots of the other main tool classes, the scrapers and burins, shows scraper discard around the hearth zone 


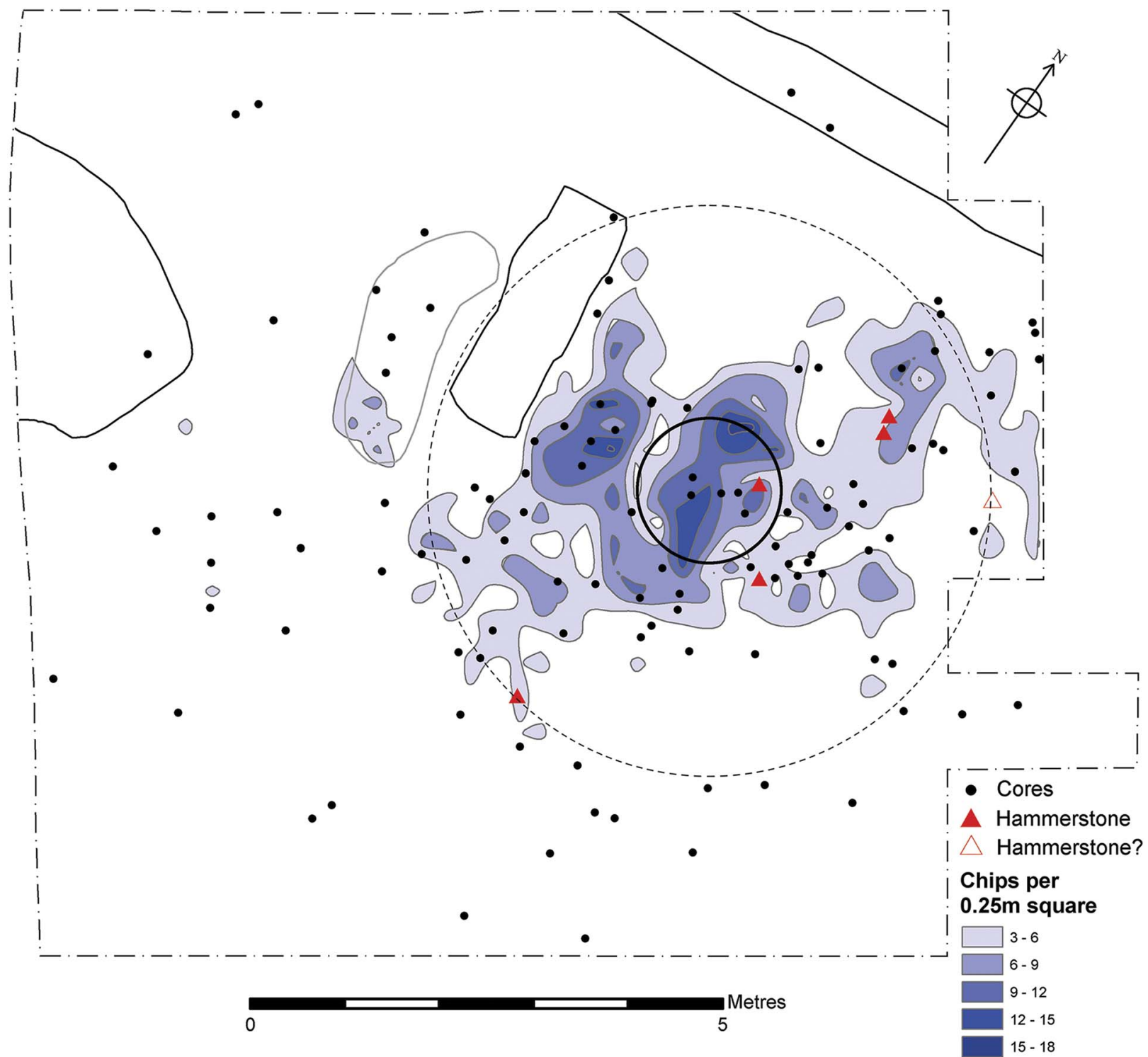

Fig. 25.

Cores and hammerstones distribution on a cell density plot of contoured micro-debitage. A putative tent ring of $6 \mathrm{~m}$ is placed concentric to the reconstructed hearth

with a southerly bias, and as with the microliths a dispersal beyond the hearth zone to the south-west (Fig. 28). Plotting of tools with use traces shows an overall similar distribution but with some patterning. To the south-west of the hearth is a cluster of microliths with impact traces, overlapping with a cluster of four tools that were used to cut meat (Fig. 29).

To conclude, the spatial analysis has supported the proposition that the Area 2 remains are in a primary deposit and that the Mesolithic artefacts are in situ (with the exception of the identified later disturbances from the tree throw pit, later prehistoric features and, unfortunately, a recent geotechnical test excavation trench). The principal focus of activity was around a central hearth, dated towards the beginning of the occupation sequence ('east hearth' in the dating section above). The great majority of lithic and faunal remains are probably related to this phase of occupation, and later visits to the site have a negligible lithic presence (but note the probable expression in the few smaller geometric microlith forms). 


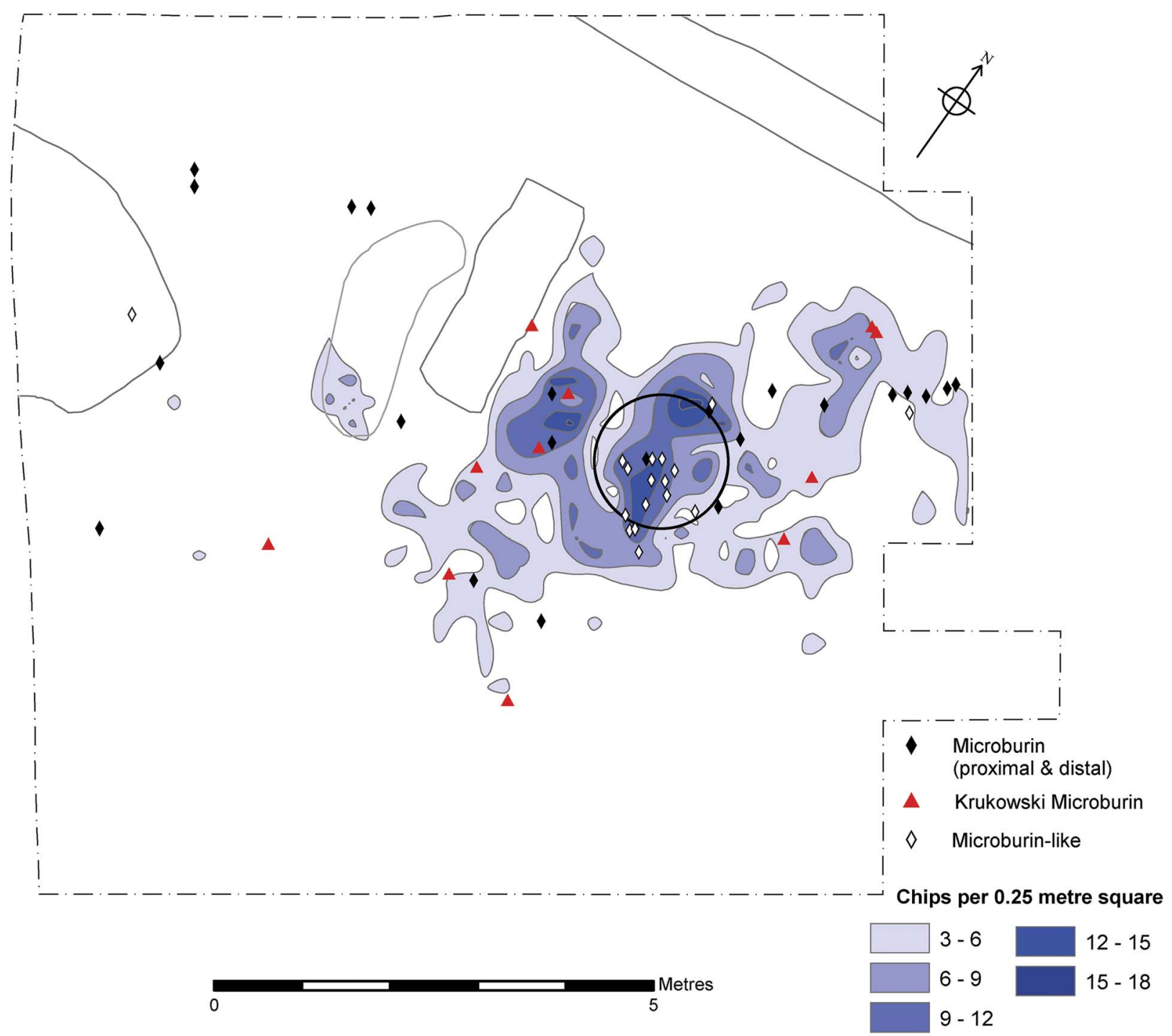

Fig. 26.

Plot of microburins

There are some indications that these principal activities were bounded, ie, were undertaken within the confines of a circular tent structure. This activity included a multitude of demonstrable tasks: knapping, tool production, hunting kit tool maintenance, animal processing with butchery, and secondary animal product processing (dry and fresh hide working, antler? working) and some working of plant material. These activities show some spatial foci, although overlapping to a degree.

Notwithstanding the equivocal evidence for a tent structure there does appear to be a focal spatial integrity to the remains that would be unexpected had the site been subject to intensive re-occupation episodes. Both macroscopic and microwear lithic research (above) has demonstrated the excellent condition of the artefacts, and while trampling may have been a component in site formation it appears to have been minimal.

\section{DISCUSSION}

Characterising Honey Hill assemblage types

The Honey Hill type assemblage was proposed as an archaeological entity by Michael Reynier (1997; 2005), following pioneer research by Roger Jacobi and 


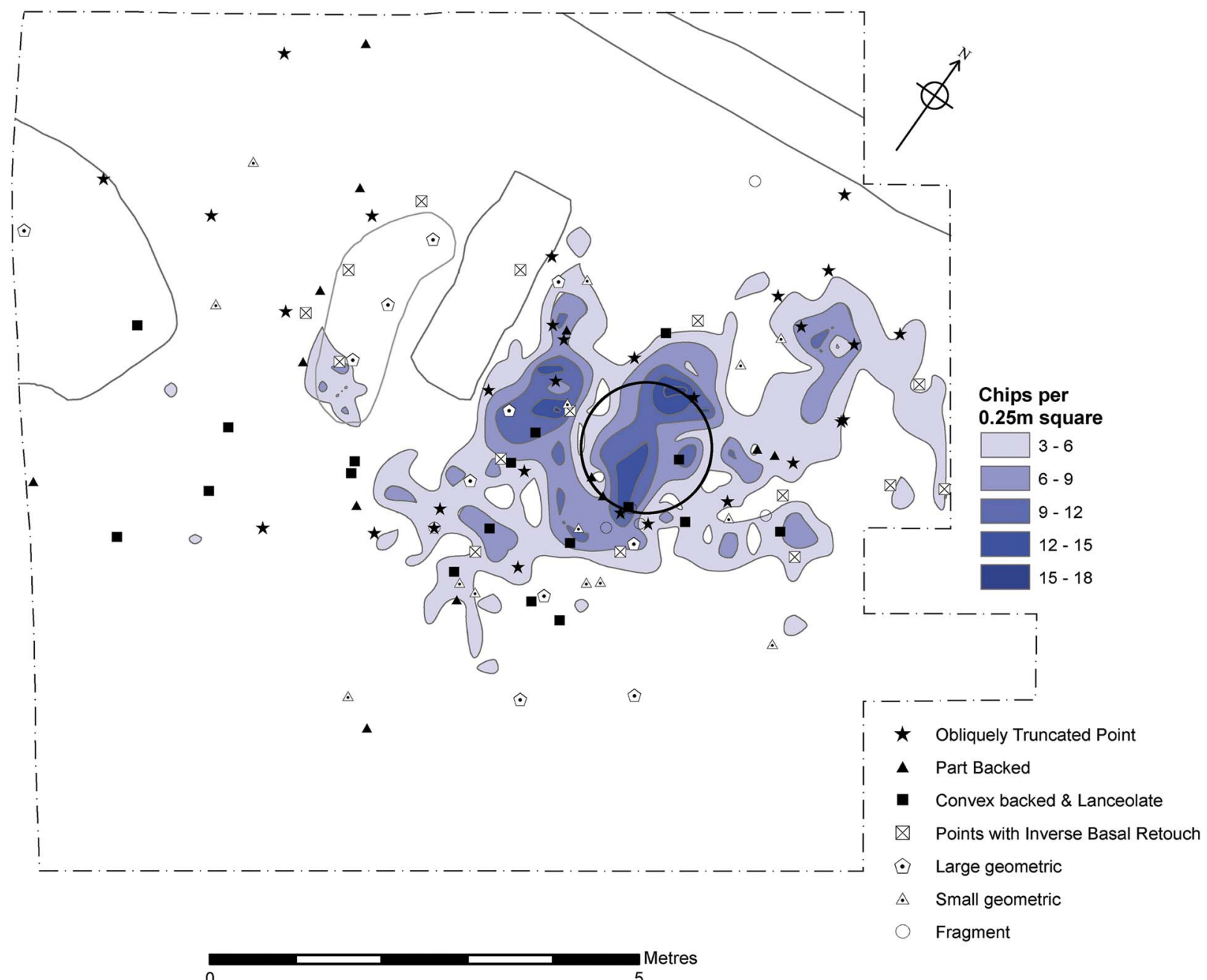

Fig. 27.

Plot of microliths

then further study by Alan Saville. The microlith typological data drawn from Jacobi's $\mathrm{PhD}$ on the British Mesolithic and his subsequent research in the 1970s were used to undertake computer cluster analysis (Jacobi 1979; Switsur \& Jacobi 1979); Jacobi first recognised what was to later become known as the Honey Hill assemblage type during his cluster analyses of microlith types for England and Wales. In a consideration of the chronology of 'Early postglacial industries of England and Wales' he drew upon his novel microlith typology of 32 types arranged into four broad categories (Jacobi 1978):

1. Broad microliths $\geq 7 \mathrm{~mm}$ wide including obliquely blunted (truncated) points, convex-backed pieces, isosceles triangles, and trapezes (classes 1-4);
2. Narrow microliths $<7 \mathrm{~mm}$ wide including scalene triangles, rods, micro-rhomboids, boat-shaped, pearshaped, and micro-tranchet forms (classes 5-9);

3. Hollow based or Horsham points (class 10);

4. Inversely retouched points ranging from leaf-shaped to semi-circular in outlines (classes 11-13)

Typological and chronological analyses identified earlier and later Mesolithic clusters, while subsequent cluster analysis presented different groupings within the clusters. Analysis of the later sites presented 24 examples that were assigned to cluster $\mathrm{B}$, a group ranging across southern England, Wales, and the Midlands. This cluster included groups with microliths of accepted later Mesolithic form (classes 5-8, 


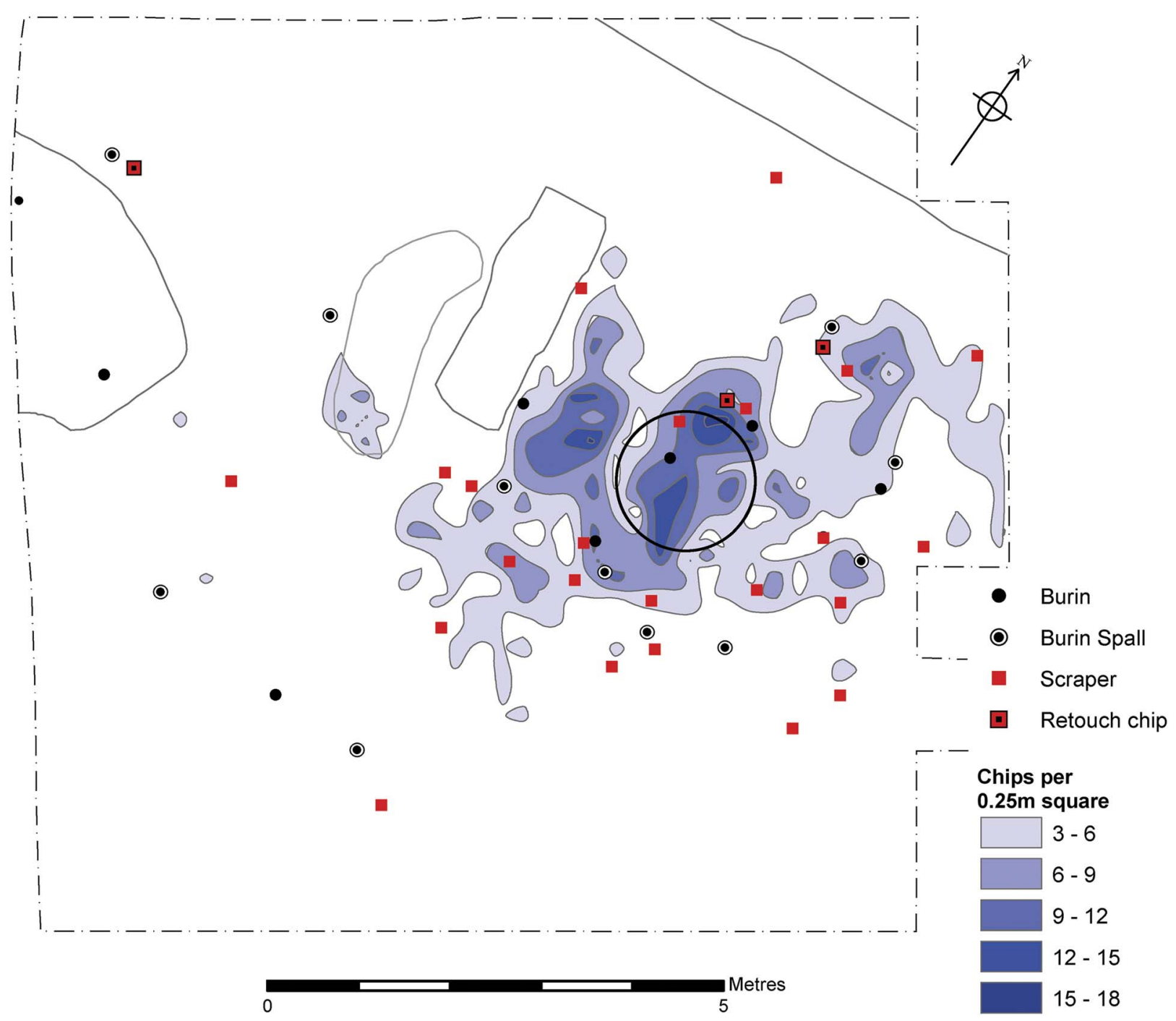

Fig. 28.

Plot of scrapers and burins

occasionally 9) but also a 'noticeable, often high, proportion of early Mesolithic shapes' (ibid., 47). A regional sub-clustering was noted whereby in the Midlands and East Anglia sites contain many leafshaped points (class 11) and in southeastern England, sites contain Horsham points (class 10)'. In another study, investigating the south-western Mesolithic Jacobi (1979) presented four clusters, the 'new' fourth cluster comprising three assemblage types. The first of these were summarised as having obliquely backed pieces dominating all other shapes of scalene triangles, convex backed, and lanceolate pieces. All such assemblages had inversely retouched pieces of which the most common type was the lanceolate microlith trimmed by what is often flat and noticeably invasive flaking to a pointed or rounded tail and a symmetrical leaf-shaped outline (Jacobi 1978, fig. 6 shape 11) ... restricted to the English Midlands and East Anglia' (Jacobi 1979, 63). He posited four English groupings in the 'Later Early Flandrian Hunting Period', one of which was termed 'assemblages of Midlands and East Anglian type' or 'East Anglian/Midlands technology' (ibid., 67, fig. 11).

Alan Saville provided a type site with his detailed analysis of a large surface scatter from Honey Hill, Elkington, Northamptonshire (Saville 1981a), while 


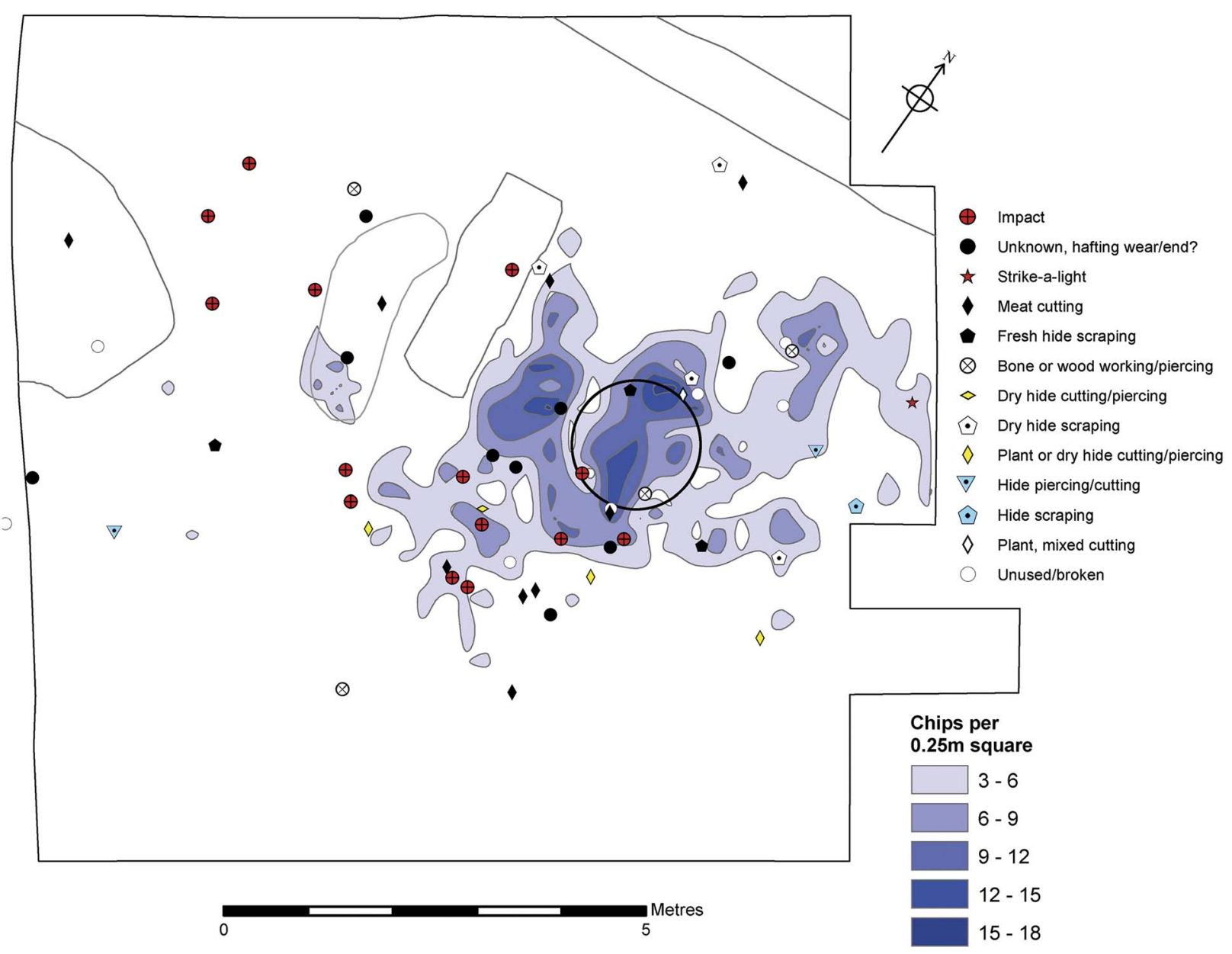

Fig. 29.

Plot of tools with microwear traces

further typological study was made of another three surface scatter sites with similar assemblages from east Warwickshire (Saville 1981b). Several other sites from east Warwickshire were also identified and mapped but no further details were published. The site distribution reflects collector Ron Waites's local cycling catchment area. Both Jacobi and Saville recognised the point with inverse basal retouch as a diagnostic type in these assemblages, and also commented upon the likely close affinity with Horsham assemblages of southern England.

Michael Reynier's doctoral study of the British Early Mesolithic built upon the groupings identified by Jacobi, focusing on three major assemblage types, namely Star Carr, Deepcar, and Horsham (Reynier 1997; 1998; 2005). Some consideration was also given to Honey Hill assemblages and a summary definition of such was given (Reynier 2005, 27):

- Oblique points, 20-60\% of microliths (including partially backed points);

- Convex backed points, $15-30 \%$;

- Isosceles triangles and rhomboids, low at 5-15\%;

- Scalene triangles, very variable at $2-30 \%$;

- Basally modified points, all of the inverse variety, 5-20\%;

- Strong lateralisation to the left, $>90 \%$;

- High proportion of points with additional retouch to the leading edge, $25 \%$;

- Mean length of 21-6 mm (small when compared to Early Mesolithic Star Carr and Deepcar assemblage types); 
- Slender microlith outline;

- Frequent end scrapers but low frequencies of burins;

- Core tools include flake axes.

There remains uncertainty over the degree of later admixture in the Honey Hill type field scatter assemblages. Saville (1981a) noted that the eponymous site assemblage contained no geometric microliths, whereas the east Warwickshire sites included varied proportions of such (Saville 1981b). The geometric microliths were interpreted as intrusive pieces, later admixture to the assemblages from subsequent occupations. However, Jacobi (1978) made a distinction between geometric microliths made upon broad blades and those made from narrow blade supports, with the implication that the former may be earlier than the latter. Reynier (2005) similarly made a metrical distinction between macro- and micro-geometrics, suggesting that the former may be found in true association within Honey Hill assemblages, and can be seen to herald the typological changes that were soon to occur in the later Mesolithic. Indeed, assemblages such as that from Peacock's Farm, Shippea Hill, Cambridgeshire (Clark 1955) may represent later developments of the Honey Hill phenomenon.

\section{The Asfordby typo-technological characterisation}

The Asfordby assemblage compares well with the other published Honey Hill type assemblages: all of the microlithic forms are present and within the proportions given by Saville (1981a; 1981b) and Reynier $(2005,27)$. Table 7 shows the mean dimensions of the microliths from Asfordby, Honey Hill, and the three east Warwickshire sites studied by Saville (1981b) and these can be seen to be of a very similar range. One of the more notable characteristics is the very high frequency of microliths with sinistral retouch, according with Honey Hill type assemblages but contrasting with classic assemblages of Early and Late Mesolithic types. The presence of a small number of geometric microliths presents the issue of assemblage integrity, with some or all perhaps indicative of later visits to the site. However, the differences between the Honey Hill and the Warwickshire assemblages might also suggest that the differences reflect chronological developments, and/or differences of site function and activities performed there. There is an apparent bi-modal size distribution of scalene triangle microliths in the Asfordby assemblage and it is suggested that the larger examples form a component of the Honey Hill type assemblage while the smaller ones are likely to be later additions.

There is a relatively high proportion of end scrapers in the tool assemblage. While there are several classified burins only one showed sign of hide cutting, so some or all of the remainder might be burins de fortune, ie, accidental pieces. Tool inventories for other Honey Hill sites are not available, but it is to be noted that a high proportion of scrapers and low incidence of burins also occur in Horsham type assemblages (Reynier 2005, 22).

The radiocarbon programme has provided the first scientific dating of a Honey Hill type site, with a cluster of dates showing the start of occupation around $8360-8000$ cal BC (modelled date at $95 \%$ probability). The principal activities around the east hearth occurred

TABLE 7: METRICAL COMPARISON OF MICROLITHS FROM REPORTED HONEY HILL TYPE ASSEMBLAGES

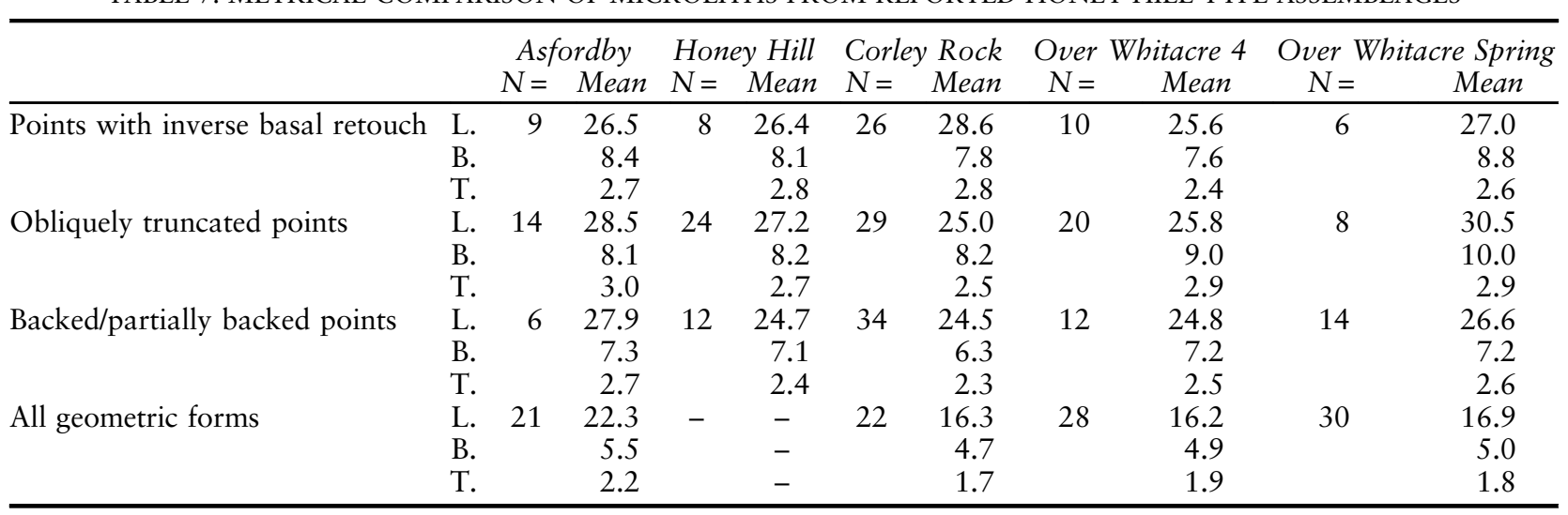

L. = length $(\mathrm{mm}) ;$ B. = breadth $(\mathrm{mm}) ; \mathrm{T} .=$ thickness $(\mathrm{mm})$ 


\section{L.P. Cooper \& W. Jarvis. MAKING \& BREAKING MICROLITHS: MIDDLE MESOLITHIC SITE, ASFORDBY, LEICS}

between $8220-7840$ cal BC (95\% probability) or 8100 7890 cal $B C(68 \%$ probability) and $7960-7530$ cal $B C$ (95\% probability) or $7930-7730$ cal BC $(68 \%$ probability). The probability distribution for the number of years during which the east hearth was in use is heavily skewed towards a shorter duration, such that this principal occupation may have occurred around $8000 \mathrm{cal}$ BC.

The dating has provided strong support for the suspected close chronological relationship of Honey Hill and Horsham type lithic assemblages (Saville 1981a; Reynier 2005). These two archaeological entities would seem to have been temporally positioned around the late Preboreal and early Boreal, reflecting wider trends in north-west Europe. The following sections will address more fully the relationship between these two British assemblage types and with wider typo-technological Middle Mesolithic trajectories across the Channel.

\section{A British Middle Mesolithic?}

A conventional division of the British Mesolithic into Early and Late stages has been based upon typologies of microliths (Jacobi 1973; 1976; Mellars 1974) and technological criteria (Buckley 1924; Radley \& Mellars 1964; Pitts 1978; Pitts \& Jacobi 1979), although many Historic Environment Records still do not present such temporal division (Myers 2006). Furthermore, there are good indications that other chronological stages may be identified in the British record (Reynier 2005; Jones 2013) and that a simple early:late dichotomy actually makes the British Mesolithic 'timeless and unchanging' (Conneller \& Higham 2015, 157). Reynier (2005) suggested that three identified Early Mesolithic assemblage types (Star Carr, Deepcar, and Horsham) showed a temporal succession, and a recent dating programme lends support and demonstrates likely chronological overlaps, as Reynier speculated (Conneller et al. 2016a). Jacobi (1978) hinted at the concept of a British Middle Mesolithic when he suggested a relatively intermediate temporal position for Horsham type assemblages: 'they might be younger in age than the Early Mesolithic but older than the later Mesolithic as dated in this country'. He pointed to the similarity of Belgian and French assemblages (microliths with basal modifications), dating to 'close to $7000 \mathrm{bc}$ ', approximately 8000 cal BC. Furthermore Saville (1981a) suggested a close affinity between Horsham and Honey Hill assemblage types and suggested that they were near contemporary.

Reynier (2005) amplified the view that Horsham and Honey Hill assemblages might be related and broadly contemporary, referring to the basally modified microliths in the Horsham type assemblage from Beedings Wood, Sussex (Clark 1934). In addition to classic Horsham points there are 16 inversely based points of Honey Hill type, with both pointed and rounded bases (ibid., fig. 10). These were classified by Clark as his Class E (but mis-named as Class G in fig. 10). Clark (ibid., 52) believed the Beedings Wood assemblage to be free from later admixture, unlike the other reported 'Tardenoisian of Horsham' sites. However, as with the Honey Hill sites, the Clark's Horsham typological construct was based upon surface scatters of quite large size with, obviously, no chronological control. Barton and Roberts (2008, 224-5) also regarded a connection between the two assemblage types, and their suggested chronological position, describing them as 'Early Mesolithic of Boreal'. They interpreted the principal microliths of both Horsham and Honey Hill as developed armatures and linked to expansion of groups into the deciduous forests. Following Jacobi's reasoning Gardiner (nd), in an assessment of the Mesolithic of southern England, was the first to describe the Horsham industries as 'Middle' Mesolithic, while the term has also been used to describe an assemblage with Horsham points from Rock Common, Washington, West Sussex (Harding 2000). This is an attractive term in that it describes a distinct archaeological entity, in a defined period and geographical position. It is proposed that 'Middle Mesolithic' best describes the related Horsham and Honey Hill assemblage types. Such an adoption would allow greater temporal understanding of the British Mesolithic (Conneller \& Higham 2015) and allow more direct comparison with continental developments where a tripartite division is commonly followed (Fagnart et al. 2008b). Unfortunately there are areas of the UK, such as northern England, Wales, and Scotland, where a Middle Mesolithic is not recognised (Saville 2008; Waddington 2007). However, a single Honey Hill type microlith was reported from Cramond, Scotland, in association with large scalene triangles, some of which seem to more closely resemble convex backed forms. The early dates from the site have been seen as heralding in the beginning of the later Mesolithic (Saville 2008). Likewise, the recent 
sites along the north-east coast, such as Howick and East Barns, are also seen as indicative of the incursion of a later Mesolithic 'narrow blade' group into northern Britain from Doggerland (Waddington 2007; 2015). Perhaps further typo-technological lithic studies may identify subtle differences between these northern early Boreal sites when compared to late Boreal and Atlantic Mesolithic sites, allowing for a wider adoption of a tripartite division of the British Mesolithic.

\section{Cultural connections inside and outside of Europe}

Diachronic developments in the British Mesolithic, 'inside and outside of Europe', were outlined by Jacobi (1976) but at the time of his research the Midlands type assemblages (later termed Honey Hill) were not recognised. Considering the possible wider origins of the British Early Mesolithic groups Reynier (2005) applied a typological study of microlith types across north-west Europe. A series of Microlith Assemblage Stages (MAS 1-4) were proposed for the Early Holocene, c. 10,000-8500 вP. By about 90000 вр (c. $8200 \mathrm{cal} \mathrm{BC}$ ), around the beginning of the Boreal, is Reynier's MAS 3b, a stage including the British Horsham group. Similar microliths occur across much of north-west Europe including northern France, Belgium, the Netherlands, and Germany. Broadly, the microlith range includes basally modified points, oblique points, and triangles. Despite such similarities Reynier $(2005,116)$ suggested that there were no direct analogues for the British Horsham and Honey Hill assemblages. For Reynier the closest parallels were sites in north Germany with oblique points, isosceles triangles, transverse basally modified points, and some scalene triangles. Some of the latter have short concave margins that can be compared to Horsham points.

However, there are several Middle Mesolithic sites in northern France that present close typological similarities to Horsham (Fagnart et al. 2008a) and Honey Hill assemblages (Ghesquière 2011). In the Somme basin there are sites such as Blangy-Tronville (Thévenin 2008) and Saleux (Fagnart et al. 2008a) where asymmetric hollow based forms of pointes a base retouché occur. In a UK context these would be described as Horsham points. At Saleux La Vierge Catherine (lower bed) there are a series of asymmetric hollow-based points together with segments de cercle, what might be termed crescents or convex backed microliths. The assemblage was associated with fauna of wild pig (Sus scrofa) with a radiocarbon date of $8645 \pm 70$ вр (OxA-4929 (Lyon-78)). At a second site at Saleux, Les Baquets, locus 224a there are a number of similar hollow-based microliths (Fagnart et al. 2008a) while nearby in the Thérain Valley several sites at Warluis also present microlith forms that can be compared to Horsham sites including oblique points, isosceles triangles, large scalene triangles, and asymmetric points with basal retouch, sometimes of hollow-based type (Ducrocq et al. 2008). A similar range to the latter is recorded at Chéronvilliers, Eure, where there are hollow-based and oblique points, together with isosceles and scalene triangles (Souffi 2008). At Closeaux á Rueil-Malmaison, Hautsde-Seine (Lang \& Sicard 2008) there are points with inverse basal retouch, slightly hollow, with scalene triangles and segments (convex backed). The latter are slender and some examples have opposed retouch which, where extensive, make them resemble Sauvetterian points (ie, a small, lanceolate microlith with retouch along both lateral margins).

Fagnart et al. (2008a, 114) have presented a detailed typo-technological summary of the Saleux assemblages. Blade and bladelet debitage was by means of opposed platform cores, often with a preferential platform allowing the repair of knapping accidents and to preserve a less pronounced longitudinal convexity. Debitage was initiated from the core front with a progression to the flanks. Platform preparation was by means of core tablet removal from the front of the core. In most cases the back of the core had little removal, remaining cortical. Abandoned cores were of $30-50 \mathrm{~mm}$ optimal length. Bladelets ranged from $23 \mathrm{~mm}$ to $57 \mathrm{~mm}$ with a median of $35 \mathrm{~mm}$. Bladelets were straight or slightly curved with their talons, the overhanging spurs at the core front, having been abraded. Soft stone percussion was evident from the features as described by Pelegrin (2000). All in all, the debitage method is very akin to that recorded for the Asfordby assemblage (Cooper above). However, the core technology is somewhat divergent from that described by Reynier for Horsham industries where helical cores are common (although this may reflect in part the intensive working of cores due to scarce raw material of good quality).

At Saleux the points with retouched bases formed c. $30 \%$ of the microlith group and were described as slender asymmetrical points with backed left sides and 


\section{L.P. Cooper \& W. Jarvis. MAKING \& BREAKING MICROLITHS: MIDDLE MESOLITHIC SITE, ASFORDBY, LEICS}

natural or retouched convexity on the right. This retouching of the right leading edge was usually light and marginal. The points are lop-sided to the left and the bases are oblique and frequently concave. The bases are fashioned by a series of first direct, followed by inverse, retouching. The points have hollow bases, sinistral lateralisation, asymmetric form with additional retouch on the leading edges and are seen as direct analogues with Horsham points as defined by Clark (1934). Fagnart et al. (2008a) suggest that the Saleux sites belong to a groupe de l'Ourlaine dating to the end of the Preboreal and the first half of the Boreal based on the point form and associated crescents (Gob 1981; Crombé 1999; Crombé \& Cauwe 2001).

Ghesquière (2011) reports on a series of lithic scatters in the Nord Contentin peninsula of Normandy which have produced assemblages with microliths with inverse basal retouch of Honey Hill type. The Roc de Gîte site at Auderville produced many microliths with retouched bases (rounded and straight) including several examples with inverse removals and these were compared to examples from the Honey Hill type site of Two Mile Bottom (ibid., 15-17 \& fig. 6). The Centrale EDF site at Flamanville mostly comprised microliths with oblique truncation but also two crescents, a Rouffignac point, a Sauveterrian point, and two pieces described as very obliquely truncated points with rounded base, one of which has an inversely retouched (ibid., fig. 4). Ghesquière also reports sites with Horsham group affinity in the Manche Est zone of Normandy and Picardy, and suggests direct maritime contacts with England in the Middle Mesolithic. The Middle Mesolithic appears to have been a time when maritime activity is manifest with many of the British islands colonised at this time (Conneller et al. 2016b). It is suggested that such Middle Mesolithic sites in northern France are outliers of essentially insular developments in the British peninsula.

Reynier (2005) suggested that the different Early Mesolithic entities may equate with different tribal groupings and that their cultural origins might be traced to the continent. Star Carr type sites have a long recognised affinity with the Maglemosian (Clark 1932) while Deepcar type sites have a general affinity with developments in the southern half of the North Sea basin representing adaptations to the closed pine forest (Reynier 2005, 119 \& 122). Reynier has suggested similar roots for the Horsham type sites while some northern French sites present a closer analogue, suggesting parallel developments along either side of the Channel embayment. The inland distribution of Horsham and Honey Hill type sites seems to be an infilling of the English landscape in the Middle Mesolithic. This process probably reflects both an opening of new areas in ecological terms and population pressure from the loss of the Doggerland plain (Coles 1998) and diminishing coastlines to sea rise.

\section{Geographical range and landscape setting of the Honey Hill group}

As the Honey Hill type assemblages have been recognised since the 1970s one might accept that their known distribution in central England is probably, more or less, a true reflection of their territorial extent (Fig. 30): major sites are known from the West Midlands, East Midlands, and East Anglia (Jacobi 1978; Saville 1981a; 1981b; Reynier 2005). It is likely that there would have been coastal sites that were lost to rising sea levels in the North Sea area off the present

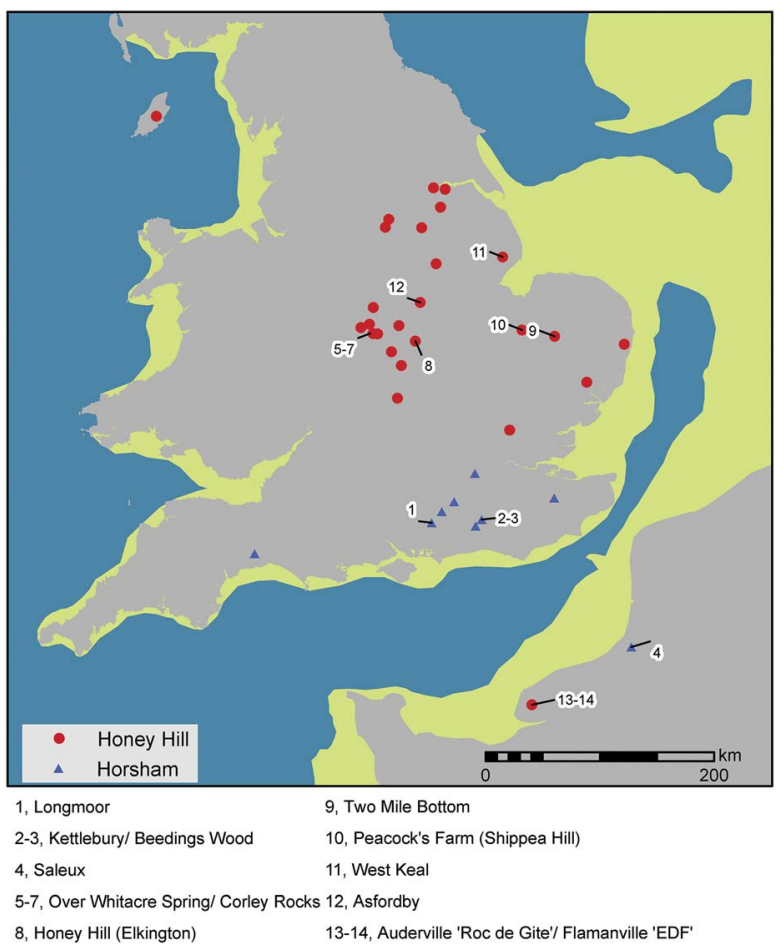

Fig. 30.

Distribution of Middle Mesolithic Honey Hill and Horsham type sites with approximate line of coast at 10,000 вР (from Sturt et al. 2013, fig. 6) 
Norfolk and Lincolnshire coastlines. Recent modelling suggests that this area saw considerable inundations at the Preboreal-Boreal transition (Conneller \& Higham 2015). Indeed the Isle of Man and the Normandy sites, and perhaps the Cramond site, suggest that the Honey Hill culture may well have had a maritime expression.

Undoubtedly other Honey Hill type assemblages, or components thereof, may have been discovered but not recognised. The recent publication on the Mesolithic assemblage from Blake Acre, Bradwell, Derbyshire is a case in point (Guilbert 2013). The report included a leaf-shaped point with inverse basal retouch, the classic Honey Hill microlith type, but this is subsumed into the Early Mesolithic period (Jacobi 2013). Early and Late Mesolithic assemblages are plotted for a large area of the Derbyshire uplands, and it is wondered how many of the Early Mesolithic sites might include Honey Hill type microliths.

The cluster of east Warwickshire sites was discovered in the 1960s by Mr Barry (aka Ron) Waite: Saville (1981b) maps nine major and 11 smaller sites. Their distribution in some ways mirrors Waite's collecting forays from Nuneaton on his bicycle, but a geological preference is apparent. Most sites are located on the upland plateau of the Warwickshire Group Siltstone and Sandstone, formerly the New Red Sandstone. Corley Rock is a hilltop site close to the east edge of the plateau while Over Whitacre Spring and Over Whitacre Site 4 are on slopes of the sandstone. The other mapped sites are also located along the edge of the east Warwickshire plateau, a watershed between the drainage basins of the West and East Midlands. The major sites have commanding views across the plateau and into the tributary valleys of the Avon to the west and south and the headwaters of the Trent Basin tributaries of the Dove, Mease, and Soar to the east and north. Waite subsequently fieldwalked a wider terrain including areas with clay bedrock though no significant Mesolithic sites were found.

The Honey Hill site is in Elkington parish in the Northamptonshire uplands situated at $213 \mathrm{~m}$ on bedrock of Northampton Sand of the Inferior Oolite Series with good views over the Avon Valley and the Birmingham plateau (Saville 1981a). No other Honey Hill assemblages are reported from Northamptonshire but is seems likely that such may occur within the chronologically undifferentiated Mesolithic sites of the county. Phillips (2000) suggests that many of the Northamptonshire upland Mesolithic sites are located at the headwaters of the major tributary rivers
(Ise, Welland, Warwickshire Avon, and the Brampton Arm of the Nene) and reflect movement and exploitation not only along the valleys but also between the major river systems. The east Warwickshire sites occur in a similar landscape context. A Mesolithic preference for plateau edge and other prominent topographic settings has also been noted in Leicestershire and Lincolnshire (Myers 2006). Likewise the West Keal sites are on a hilltop location on sandstone on the southern edge of the Lincolnshire Wolds, overlooking the lower wetlands around the bay of the Wash.

The vast majority of Horsham sites are also located on permeable geologies (Clark 1932; Rankine 1949; Jacobi 1981). As with the Mesolithic people of southern England, it is doubtful that the folk in the Midlands were keen geologists (Gardiner n.d.) but, like the Horsham sites, there does seem to be a distribution of the major sites on permeable geologies. The location of the larger sites might best be explained by viewing such locations in terms of optimal foraging opportunities. They are located near topographic and geological boundaries that are likely to have been rich ecotones between the upland plateaux and wetlands of the major river valleys and the Wash delta. Many of the upland sites also show proximity to spring lines. The higher grounds with partly exposed rock geologies may also have presented lighter forest cover that could have been more easily managed. There has been considerable debate over the Mesolithic expansion of human groups onto the claylands of the Midlands (Clay 2002) but the lack of temporal control on the HER data precludes consideration for this study. However, it would be surprising if there was overall avoidance of claylands in the Middle Mesolithic as deciduous forest would have spread over such strata. Indeed, glacial till was the ultimate source of local flint raw material in the Midlands, so we might at least expect provisioning sites on the clay strata.

The Asfordby site is situated on the right bank of the Wreake, a side valley of the Soar, which is itself a major tributary of the river Trent. The Wreake, rising at Stapleford Park in the Leicestershire Wolds, is a small river in a relatively deep and narrow valley cutting through a mantle of Anglian glacial till into underlying Lias deposits. The Wreake valley has islands of flanking sand and gravel terrace (Birstall member), and also presents Baginton Sand and Gravels from the pre-Anglian river Bytham. The narrow cross-section through multiple geological strata would have provided a wide ecological range within 


\section{L.P. Cooper \& W. Jarvis. MAKING \& BREAKING MICROLITHS: MIDDLE MESOLITHIC SITE, ASFORDBY, LEICS}

a small catchment area. The Wreake also effectively provides a corridor through the claylands linking the uplands of Charnwood to the west and the Jurassic ridge to the east, these perhaps areas in which larger base camp sites may be located.

\section{Settlement and economy}

Reynier (2005) presents an interesting diachronic perspective with his model of Mesolithic settlement in the early Holocene, giving due consideration to changing climate and ecology in the Preboreal and early Boreal. The earliest true Mesolithic manifestations are Star Carr type sites, with upland and coastal settlement patterns. Site types include short term (1-10 years) base camps and task sites (satellite resource provisioning sites) on a seasonal round. Longer term settlement ( $>50$ years) would be stable with slight shifts. This settlement system supported an 'intercept' foraging strategy with aggregated seasonal hunting at specific times and places.

Deepcar type sites appear a little later in the Preboreal, coinciding with the spread of dense pine afforestation, and settlement appears to be mainly focused in the larger river valleys. These provided choice locations with concentrated resources in the otherwise resource-poor woodland. Reynier's settlement model predicts a highly mobile seasonal round and longer term settlement pattern: base camps are focal such that harvested resources are returned there rather than processed in specialist task sites away from the base camp. An 'encounter' economic strategy is envisaged whereby hunting of prey is opportunistic. Base camps would be moved every few years as an area became depleted of resources.

With the succession of open canopy deciduous forest at the close of the Preboreal, an increase in biomass occurred, but accompanied by a dispersal of animals. A tri-partite short term settlement system is envisaged for the Horsham type sites of this period with base camps, task sites, and the development of fixed facility sites (Reynier 2005). The latter might include the establishment and maintenance of forest clearings to attract certain animals, together with investment in traps, hides, and lures. It would seem likely that the increased biomass of the woodland would have allowed a greater economic use of plant resources, with the intensive exploitation of such in defined areas effectively being forest 'gardens'. Such investment in fixed facilities would allow for the intensive manipulation of plant and animal resources in a predictable manner (Reynier 2005, 125). With a sustainable foraging strategy there would have been closer ties to the land and a stable, fixed settlement system can be envisaged.

Returning to the evidence for Honey Hill type sites it is possible to interpret the larger sites as base camps, possibly with minimal shifting over several years. Such sites might be described as truly 'persistent places' in the landscape (Barton et al. 1995) in that they were settlement focal points for generations. However, the Asfordby occupation does not appear to belong to one of these larger aggregation sites: the excavation of the larger areas of the housing development did not produce any evidence for contemporary remains (although the Middle Mesolithic site did extend into the neighbouring school field). It is tempting to see the site as a resource provisioning location but more than a simple task site, and one occupied by a family group (see above). Activities performed at the site include lithic raw material sourcing, knapping, tool production/ maintenance, hunting of pig and deer, animal processing, and cooking. The site may best be interpreted as a fixed facility site (Reynier 2005) where there is considerable investment in the locale with repeated visits for seasonal resource exploitation. Its location on the side of a small valley is similar to Horsham type settlement and can be seen as part of an infilling of the landscape, that became available with the development of deciduous woodland (ibid., 99-100).

\section{Microlith form and function in the Middle Mesolithic}

In the previous section it was suggested that a common techno-complex of microliths could be identified across north-west Europe at the Preboreal-Boreal transition. This section will address the issue of form and function of the Honey Hill microlith types as a part of this wider techno-complex. There is a longstanding conventional view in Britain and Europe that microliths are principally interpreted as components of archery equipment, axial points, and barbs for arrow projectiles (Clark 1932; Mellars 1976; Myers 1989; Rozoy 1992). It has been suggested that microliths could have served alternative uses as hafted components of plant processing equipment (Clarke 1976; Zvelebil 1994) but where hafted microliths have been preserved they are invariably parts of projectile equipment, further supported by finds of microliths 
embedded in bone (Myers 1989, 80-1). Some support for alternative microlith function has emerged from microwear studies and Asfordby has presented examples that have been used for butchery, hide working, and plant cutting activities. However, at Asfordby, and many other sites of the Early-Middle Mesolithic, there are clear indications for many microliths having a projectile function.

The exhaustive study of the microlith assemblage from Verrebroek, Belgium has greatly informed our understanding of microlith form in the late Preboreal and Boreal (Crombé et al. 2001). With few exceptions the microliths could be related to bow hunting technology. Impact damaged pieces demonstrated that scalene triangles and crescents were preferably used as barbs while unilaterally backed points and basally modified points were used exclusively as tips. The function of obliquely truncated points was uncertain but the lack of impact damage might suggest their use as barbs (ibid., 267). At Asfordby each of the major classes of microlith had examples with impact damage, although the predominant types were convex and partially backed forms, often with additional retouch. These pieces tend to have a slender, leaf-shaped silhouette.

In discussing technological changes around the Preboreal-Boreal transition Crombé et al. (2001) suggest that, during this period, there was a dramatic increase in microliths that served as projectile points and they speculate that the lithic weapon heads replaced bone and antler points, a suggestion first offered by Mellars (1976). Radiocarbon dated osseous barbed points of the Late Upper Palaeolithic and Early Mesolithic in north-west Europe appear to become obsolete around $8150 \mathrm{cal}$ BC. The lack of impact damaged microliths at Star Carr (Dumont 1988) may be a direct corollary of the use of osseous points in preference to lithic tips. Crombé et al. (2001) envisage improvements in hunting technology, viewing stone tipped arrows as more lethal in terms of penetration and breakage, thereby exacerbating any trauma and hastening death. Their experimental studies indicated that lithic-tipped weapons are most effective for killing prey weighing in excess of $40 \mathrm{~kg}$.

In the context of the British Isles it has also been suggested that hunting technology adapted during the Early Mesolithic as larger and more elusive prey, such as forest dwelling elk, deer, and pig, required the development of more robust archery equipment (Reynier 1997, 539). Certainly there was an adoption of novel projectile microlith designs towards the end of the Preboreal. Deepcar type assemblages of this period first demonstrate the common application of additional, ancillary retouch to oblique and part-backed points, presumably to produce more robust projectile equipment. A parallel development was the use of basally modified points such as the lanceolate and similar forms found in Deepcar assemblages. Both of these traits are also seen in the Middle Mesolithic Honey Hill and Horsham type assemblages. Microlith form was further developed by the adoption of inverse basal retouch, presumably related to changes in the hafting technology of arrow tips (Reynier 1997; 2005; Barton \& Roberts 2008). In Horsham assemblages there is the universal adoption of inverse concave basal retouch, the classic Horsham point form. The defining microlith for Honey Hill assemblages is the leaf-shaped point with inverse basal retouch. The basal shaping is both flat and invasive, a distinct departure from the abrupt retouch seen in Terminal Palaeolithic and Early Mesolithic microlith technology, probably resulting from the novel application of the pressure flaking technique. Generally the Horsham and Honey Hill sites show a mutually exclusive distribution but there is a single Horsham type site, Beedings Wood, which also includes microliths with inverse basal retouch (Clark 1934).

The widespread adoption of microliths with careful basal shaping, can be seen as a development of bow hunting technology, innovative designs to allow the hafting of new types of lithic weapon tips (Reynier 1997; 2005; Barton \& Roberts 2008; Crombé et al. 2001). These technological changes might be viewed as reflections of changing hunting strategies, adaptations to changes in resource patterns in the new ecological conditions of the deciduous forests of the Boreal.

Myers (1989) has provided an appealing theoretical approach to understanding the form and function of projectile microliths during the British Mesolithic. Profound changes in microlith forms and their increased frequency from the Early to Later Mesolithic are related to changes in resource pattern and the need for 'reliable and maintainable' hunting equipment. Intercept hunting strategies are envisaged in the Early Mesolithic where aggregations of herd prey such as deer can be predicted in time and space (Myers 1989, 90; Binford 1978, 85). Such a hunting strategy provided a large predictable resource of meat and other animal products such as hides, sinew, bone, and antler. During the autumn hunt surplus meat could be cached for over-wintering, while animal by-products could be processed and worked during late autumn and winter. 


\section{L.P. Cooper \& W. Jarvis. MAKING \& BREAKING MICROLITHS: MIDDLE MESOLITHIC SITE, ASFORDBY, LEICS}

'Gearing up' for the next hunt could be undertaken in the long fallow periods between hunting seasons. The industrial processing of antler points at Star Carr (Clark 1954; 1972) is perhaps a rare archaeological signature of such activity in the Early Mesolithic. The ameliorating climate and concomitant ecological changes of the rapid forest succession of the deciduous woodland caused a demise of such an economic strategy. New forest species were added to the animal spectrum and existing species such as deer changed their behaviour, becoming less gregarious in the more closed environment (Bridault 1997; Reynier 2005). The hunting of large prey would be less predictable as hunting stands at seasonal aggregation places were lost, and an 'encounter' strategy would have been deployed for such prey.

It may be possible to draw a broad parallel with developments in the Late Upper Palaeolithic of northwest Europe, also a period of rapid climatic warming and changing environment. At this time there was also a gross change in hunting strategies from intercept to encounter strategies, with profound social, residential, and technological adaptations. Valentin (2008a; 2008b) contrasted Late Magdalenian and Late Azilian assemblages of the Paris Basin suggesting that the latter be understood as cultural adaptations to new environmental conditions. His model seeks to explain the evolution from elaborate and methodical Magdalenian lithic typo-technologies to the more simplified Azilian version. Profound ecological changes in the Late Glacial led to the replacement of the Steppe landscape by a mosaic of forests and grassland. Fundamental economic changes resulted from changing ecological conditions: with the loss of some species, arrival of new animal species, and/or changing behaviour of species. Planned and predictable seasonal hunting gave way to punctual hunting: an intercept strategy was lost and an encounter strategy became inevitable. Late Magdalenian composite osseous points with inserts of backed bladelet were replaced by hafted flint points. This can be seen as reflecting the need for more reliable and maintainable hunting equipment (sensu Myers 1989) required with encounter strategies (Valentin 2008a, 19).Technological changes, including soft stone percussion, were undertaken to allow for the production of small and medium-sized blades, the blanks for the new projectile points (for discussion of the technological differences of soft stone and soft organic percussion see Pelegrin 2000). Soft stone percussion enabled the controlled knapping of a greater range of lithic raw material. The
British Late Magdalenian (Creswellian) adaptations can be understood as heralding the start of the process of what might be termed Azilianisation. Osseous points were replaced by flint-tipped spears, and there are hints at the development of archery in the small size of some Cheddar points (Cooper 2012). Similar developments occur in the Middle Mesolithic with typological change (osseous to lithic tips, and developed microlith form), and technological change (soft stone percussion, use of local flint resources).

Reynier's (2005) socio-economic model for the Horsham Mesolithic entity can be applied to Honey Hill type sites, with large game hunting supplemented by foraging strategies to exploit a wider spectrum of animal and plant resources, with an increase in fixed facilities such as traps. The microliths used as axial points for arrows might be seen as adaptations to forest hunting where large and small animals were intercepted and/or encountered. Oak and beech mast would have provided a seasonal food source for pigs, and these could be hunted with a modified interception strategy at known foraging places. It is speculated that the larger foliate microliths may have been used for killing pig. At other times, and with other prey, encounter hunting or trapping would be necessary. The smaller microliths with impact traces such as the Sauveterrian points might reflect the hunting of smaller mammals and birds. The wider array of smaller microliths, particularly the increasing use of geometric forms, might also indicate the wider use of plant foods.

\section{CONCLUSION}

The excavation and subsequent multi-disciplinary analysis of the site has addressed each of the principal research aims while the majority of the objectives have been realised (Cooper 2011). The assemblage of lithics and calcined bone was in a primary context, preserved in a palaeosol with evidence for low dynamic colluviation, some trampling, and a likely loessic input. The Mesolithic deposit was sealed by colluvium resulting from later upslope ploughing. The lithics show good concordance as a Honey Hill type assemblage with a distinctive microlithic tool repertoire and defined technological reduction strategies. Bladelet production was systematic involving serial removal from cores with single or opposed platforms, detached using a soft stone percussor. As such, it is the first stratified Honey Hill type assemblage to be investigated, serving as a benchmark 
for future research. There are minimal intrusive lithic and calcined bone components at the site, evident from a few Late Mesolithic and Bronze Age finds and the range of radiocarbon dates. However, the spatial analysis and dating programme suggest an overall spatial integrity of the Middle Mesolithic remains resulting from short-term activities around a central hearth. The principal Honey Hill type assemblage, it is suggested, can best be associated with the earlier dates from the radiocarbon programme, around the close of the 9th millennium cal BC, perhaps into the beginning of the 8th. It is proposed that Honey Hill and Horsham type assemblages should be termed Middle Mesolithic according with similar developments elsewhere in north-west Europe at the Preboreal-Boreal transition.

The title of this paper reflects the principal focus of research, the production technology of microliths and their uses as part of composite tools. The study was predicated by the nature of the preserved remains, essentially a small Mesolithic flint assemblage with a rich, coherent microlith repertoire. We have endeavoured to address the perplexing research question of microlith form and function (Mithen 1999). Notwithstanding the possible criticism for approaching a 'boys and arrows' narrative (Finlay 2000) it is an inescapable conclusion that many of the microliths from the Asfordby site had impact traces and these can best be interpreted as axial components of arrows damaged in a hunting foray. A broad trend in hunting technology, the adoption of basally trimmed microliths as axial projectile points, can be seen not only in the UK, but also across northern France, the Low Countries, and Germany (Rozoy 1992; Thévenin 2008; Reynier 2005; Fagnart et al. 2008b). This apparent basally trimmed microlith techno-complex is a phenomenon of the late Preboreal-Boreal transition and may be indicative of widespread changes in hunting strategies in new ecological spheres presented by the warming environment. However, new microlith forms and other tools that relate to non-hunting economic activities might also be anticipated given the socio-economic and settlement models envisaged for Horsham and Honey Hill communities (Reynier 2005). Reynier describes a 'fixed facility' economic strategy, the adoption of a broader spectrum economy with intensive manipulation of animal and plant resources through the use of artificial clearings, hides, traps, lures, and gardens. Perhaps the wider range of microlith forms in Honey Hill assemblages, such as the geometrics, might indicate such a spectrum of activities.
The microliths were also examined as proxy cultural markers, an approach which might draw criticism from some quarters as heading into the pit-fall of a 'type fossil' methodology. However, we are forced to rely on the data that are available: as Saville $(1981 \mathrm{~b}, 62)$ noted, 'the microlith is the only readily distinguishable, numerically significant and spatially ubiquitous lithic artefact with a visible ontogeny during the late upper Palaeolithic/Mesolithic in England'. Besides, whatever the archaeological paradigm, a culture-historical basis is a mainstay (Gamble 2001). It has been possible to identify smaller archaeological entities within the basally trimmed microlith techno-complex defined by formal variation in such microliths. The Horsham and Honey Hill type assemblages have similar but distinctive microlith repertoires and these have mutually exclusive regional distributions.

The Asfordby site confirms that developer-led archaeology can contribute much to a better understanding of developments within the Mesolithic period. The excavation has provided a unique example of an in situ Honey Hill assemblage and allowed for a better understanding of the Middle Mesolithic of England, and its relationship to wider developments around the North Sea Basin. The small size of the excavated site and the defined activities that can be inferred have provided high calibre data, an example of how such small-scale evidence can allow the construction of 'grand theory' (Conneller 2004, 921) starting with the building block of the site assemblage and working up to the construct of a defined cultural entity. Furthermore, a general lack of faunal remains does not necessarily relegate a site to a B-list (Rowley-Conwy 1987). New data will be needed to further the understanding of the Honey Hill site types, and to test some of the propositions that have been raised in this paper and elsewhere (Saville 1981a; 1981b; Reynier 1997; 1998; 2005). Such research aims might include:

1. Radiocarbon dating of more sites is needed to provide a greater chronological control and understanding of cultural developments throughout the Mesolithic period (Blinkhorn \& Milner 2013). Can the infilling of the Midlands be traced in a south-north cline of radiocarbon dates?

2. Can we confirm the apparent changes in bow hunting technology from osseous armatures to flint-tipped arrows?

3. Can we explain the changes in hunting technology in terms of requirements for sturdier, more efficient 


\section{L.P. Cooper \& W. Jarvis. MAKING \& BREAKING MICROLITHS: MIDDLE MESOLITHIC SITE, ASFORDBY, LEICS}

weaponry (Reynier 1997; Crombé et al. 2001), and/ or the needs for more reliable and maintainable equipment (Myers 1989)?

4. How might this reflect changes in hunting practices from intercept to more encounter based strategies?

5. Do new geometric forms occur in the Middle Mesolithic and could these relate to non-hunting activities?

6. Are larger sites preferentially located and where are smaller sites in the landscape?

Acknowledgements: The fieldwork and post-excavation analysis was funded jointly by an English Heritage HEEP grant and the site developers Jelson Ltd and publication by Historic England. The authors would like to thank: Dave Parker, supervisor of the trial trench evaluation that identified the Mesolithic site; the field staff, Steve Baker, Siobhan Brocklehurst, Lara Callachan, Alice Forward, James Harvey, Andy Hyam, Keith Johnson, Greg Jones, Jamie Patrick, Anita Radini, Martin Shore, Gavin Speed, Dan Stone, and to the site volunteers Anne Craddock, Augusta Feira, Sue Henderson, Sonya Milani and; Susan Ripper for the illustration of the flint tools; Katie Davenport-Mackey for database input; Tony Gnanaratnam for wet and dry sieving and sorting of fractions; Mireya González Rodríguez for proof reading. The project was managed by Patrick Clay. Several English Heritage staff facilitated the excavation and analysis work including: John Humble, Barney Sloane, Sara Reilly and Elaine Jamieson.

\section{SUPPLEMENTARY MATERIAL}

To view the supplementary material for this paper please visit https://doi.org/10.1017/ppr.2017.7

\section{BIBLIOGRAPHY}

Avery, B.W. 1964. The Soils and Land-Use of the District around Aylesbury and Hemel Hempstead. London: Her Majesty's Stationary Office

Barton, N. \& Roberts, A. 2008. Le Mésolithique ancien en Grande-Bretagne: acquisition des matières premières et occupation du territoire. In Fagnart et al. (eds) 2008b, 219-29

Barton, R.N.E., Berridge, P.J., Walker, M.J.C. \& Bevins, R.E. 1995. Persistent places in the Mesolithic landscape: An example from the Black Mountain uplands of South Wales, Proceedings of the Prehistoric Society 61, $81-116$

Bayliss, A., Bronk Ramsey, C., Plicht, J. van der \& Whittle, A. 2007. Bradshaw and Bayes: towards a timetable for the Neolithic. In A. Bayliss \& A. Whittle (eds), Histories of the Dead: Building chronologies for five southern British long barrows, 1-28. Cambridge Archaeological Journal 17

Binford, L.R. 1978. Nunamuit Ethnoarchaeology. New York: Academic

Binford, L.R. 1980. Willow smoke and dogs' tails: huntergatherer settlement systems and archaeological site formation. American Antiquity 45, 4-20
Binford, L.R. 1983. In Pursuit of the Past. Decoding the Archaeological Record. London: Thames \& Hudson

Blinkhorn, E. \& Milner, N. 2013. Mesolithic Research and Conservation Framework. York: English Heritage, University of York \& Council for British Archaeology. Available at: http://archaeologydataservice.ac.uk/archives/ view/meso_framework/downloads.cfm

Bolt, A.J.J., Mücher, H.J., Sevink, J. \& Verstraten, J.M. 1980. A study on loess-derived colluvia in southern Limbourg (the Netherlands). Netherlands Journal of Agricultural Science 28, 110-26

Bouma, J., Fox, C.A. \& Miedema, R. 1990. Micromorphology of hydromorphic soils: applications for soil genesis and land evaluation. In L.A. Douglas (ed.), Soil Micromorphology: A basic and applied science, 257-278. Amsterdam: Elsevier. Volume Developments in Soil Science 19

Bridault, A. 1997. Chasseurs, resources animales ey milieux dans le nord de la France de la fin du Paléolithique á la fin du Mésolithique: Problématique et état de la recherce. in J.-P. Fagnart \& A.Thévenin (eds), Le Tardiglaciaire en Europe du Nord-Ouest: Actes du $119^{e}$ Congrès National des Sociétés Historiques et Scientifiques (Amiens, 1994), 165-76. Paris: Éditions du CTHS

British Geological Survey (BGS) 2013. http://www.bgs.ac. uk/lexicon, website accessed 10/4/2013

Brock, F., Higham, T., Ditchfield, P. \& Bronk Ramsey, C. 2010. Current pretreatment methods for AMS radiocarbon dating at the Oxford Radiocarbon Accelerator Unit (ORAU). Radiocarbon 52, 103-12

Bronk Ramsey, C. 1995. Radiocarbon calibration and analysis of stratigraphy: The OxCal Program. Radiocarbon 37, 425-30

Bronk Ramsey, C. 1998. Probability and dating. Radiocarbon 40, 461-74

Bronk Ramsey, C. 2000. Comment on 'The use of Bayesian statistics for ${ }^{14} \mathrm{C}$ dates of chronologically ordered samples: a critical analysis'. Radiocarbon 42, 199-202

Bronk Ramsey, C. 2009. Bayesian analysis of radiocarbon dates. Radiocarbon 51, 37-60

Bronk Ramsey, C., Higham, T. \& Leach, P. 2004. Towards high precision AMS; progress and limitations. Radiocarbon 46, 17-24

Buck, C.E., Litton, C.D. \& Smith, A.F.M. 1992. Calibration of radiocarbon results pertaining to related archaeological events. Journal of Archaeological Science 19, 497-512

Buckley, F. 1924. Appendix. In J.A. Petch, Early Man in the District of Huddersfield. Huddersfield: Tolson Memorial Museum Handbook 3

Catt, J.A. 1978. The contribution of loess to soils in southern England. In S. Limbrey \& J.G. Evans (eds), The Effect of Man on the Landscape: the lowland zone, 12-20. London: Council for British Archaeology Research Report 21

Catt, J.A. 1986. Soils and Quaternary Geology. A Handbook for Field Scientists. Oxford: Clarendon Press

Clark, J.G.D. 1932. The Mesolithic Age in Britain. Cambridge: Cambridge University Press

Clark, J.G.D. 1934. The classification of a microlithic culture: the Tardenoisian of Horsham. Archaeological Journal 90, 52-77 
Clark, J.G.D. 1954. Excavations at Star Carr Mesolithic Site at Seamer, near Scarborough, Yorkshire. Cambridge: Cambridge University Press

Clark, J.G.D. 1955. A Microlithic industry from the Cambridgeshire fenland and other industries of Sauveterrian affinities from Britain. Proceedings of the Prehistoric Society 21, 3-20

Clark, J.G.D. 1972. Star Carr: A Case Study in BioArchaeology. Reading: Addison Wesley

Clark, J.G.D. \& Rankine, W.F. 1939. Excavations at Farnham, Surrey (1937-38). Proceedings of the Prehistoric Society 5, 61-118

Clarke, D.L. 1976. Mesolithic Europe: the economic basis. In G. de, G. Sieveking, I.H. Longworth \& K. Wilson (eds), Problems in Economic and Social Archaeology, 449-82. London: Duckworth

Clay, P. 2002. The Prehistory of the East Midlands Claylands. Leicester: Leicester Archaeology Monograph 9

Coles, B.J. 1998. Doggerland: a speculative survey. Proceedings of the Prehistoric Society 64, 45-81

Conneller, C. 2004. Hunter-gatherers 'on the move'? Antiquity 78(302), 916-22

Conneller, C. \& Higham, T. 2015. The early Mesolithic colonisation of Britain: preliminary results. In N. Ashton \& C. Harris (eds), No Stone Unturned: Papers in Honour of Roger Jacobi, 157-66. London: Lithics Studies Society

Conneller, C., Bayliss, A., Milner, N. \& Taylor, B. 2016a. The resettlement of the British landscape: Towards a chronology of Early Mesolithic lithic assemblage types. Internet Archaeology 42. https://doi.org/10.11141/ ia.42.12 accessed 20 March 2017

Conneller, C., Bates, M., Bates, R., Schadla-Hall, T., Blinkhorn, E., Cole, J., Pope, M., Scott, B., Shaw, A. \& Underhill, D. 2016b. Rethinking human choices to sealevel rise: The Mesolithic occupation of the Channel Islands. Proceedings of the Prehistoric Society 82, 27-72

Cooper, L. 2006. Launde. A Terminal Palaeolithic camp-site in the English Midlands and its North European context. Proceedings of the Prehistoric Society 72, 53-93

Cooper, L. 2010. A Mesolithic Station at Asfordby, Leicestershire: Project Design for Emergency Investigation Assistance (EH HEEP ref 5899) v2.3. University of Leicester Archaeological Report, unpublished

Cooper, L. 2011. A Mesolithic Station at Asfordby, Leicestershire: Updated Project Design v2.2 (EH HEEP ref 5899). University of Leicester Archaeological Report, unpublished

Cooper, L. 2012. An open-air Creswellian site at Bradgate Park, Newtown Linford, Leicestershire. Lithics 33, 30-9

Costa, L.J., Sternke, F. \& Woodman, P. 2001. The analysis of a lithic assemblage from Eleven Ballyboes, County Donegal. Ulster Journal of Archaeology 60, 1-8

Crombé, P. 1999. Vers une nouvelle chronologie absolue pour le Mésolithique en Belgique. In A. Thévenin (ed.) \& P. Bintz (dir.), L'Europe des Derniers Chasseurs: Épipaléolithique et Mésolithique, Actes du $5^{e}$ Colloque International UISPP, Commission XII, Grenoble 18-23 Septembre 1995, 189-99. Paris: CTHS
Crombé, P. \& Cauwe, N. 2001. The Mesolithic. In N. Cauwe, A. Hauzeur \& P.-L. Van Berg (eds), Prehistory in Belgium, Special Issue on the Occasion of the XIVth Congress of the UISPP, 49-62. Anthropologica et Praehistorica 112

Crombé, P., Perdaen, Y., Sergant, J. \& Caspar, J.-P. 2001. Wear analysis on Early Mesolithic microliths from the Verrebroek Site, East Flanders, Belgium. Journal of Field Archaeology 28(3/4), 253-69

Dee, M. \& Bronk Ramsey, C. 2000. Refinement of graphite target production at ORAU. Nuclear Instruments and Methods in Physics Research B 172, 449-53

Donahue, R.E. 1986. Technomorphology, Tool Use, and Site Function in the Italian Upper Paleolithic. Ann Arbor: Microfilms International

Donahue, R.E. 1994. The current state of lithic microwear research. In N. Ashton \& A. David (eds), Stories in Stone, 156-68. London: Lithics Studies Society

Donahue, R.E. 2002. The lithic microwear analysis of the B\&Q Mesolithic and Neolithic site. In J. Sidell, J. Cotton, L. Raynor \& L. Wheeler (eds), The Prehistory and Topography of Southwark and Lambeth, 81-8. London: Museum of London Archaeological Service

Donahue, R.E. \& Evans, A.A. 2011. Microwear analysis. In R. Jackson \& D. Miller (eds), Wellington Quarry, Herefordshire (1986-96), 87-93. Oxford: Oxbow Books

Ducrocq, T., Bridault, A. \& Coutard, S. 2008. Le gisement de Warluis (Oise): approche préliminaire. In Fagnart et al. (eds) 2008b, 85-106

Dumont, J.V. 1988. A Microwear Analysis of Selected Artefact Types from the Mesolithic Sites of Star Carr and Mount Sandel. British Archaeological Report 187. Oxford: British Archaeological Reports

Edina 2013. Edina website superficial deposits map, http:// digimap.edina.ac.uk/geologyroam/mapper Accessed 15/ 04/2013

Evans, A.A. 2009. Microwear Analysis and the Role of the Microlith in Mesolithic Britain. Unpublished $\mathrm{PhD}$ thesis, University of Bradford

Evans, A.A. \& Donahue, R.E. 2012. Microwear analysis of lithics from two areas from the site of Stainton West, Cumbria: An interim analysis of stone tool use. Unpublished interim report submitted to Oxford Archaeology North

Fagnart, J.-P., Coudret, P. \& Souffi, B. 2008a. Les occupations mésolithiques du gisement de Saleux (Somme). In Fagnart et al. (eds) 2008b, 107-33

Fagnart, J.-P., Thevenin, A., Ducrocq, T., Souffi, B. \& Coudret, P. 2008b. (eds). Le Début du Mésolithique en Europe du Nord-Onest: Actes de la Table Ronde d'Amiens 9 et 10 Octobre 2004. Paris: Mémoire XLV de la Société Préhistorique Française

Finlay, N. 2000. Microliths in the making. In R. Young (ed.), Mesolithic Lifeways: Current research from Britain and Ireland, 23-32. Leicester: Leicester Archaeology Monograph 7

Finn, N. 2011. Bronze Age Ceremonial Enclosures and Cremation Cemetery at Eye Kettleby, Leicestershire. The Development of a Prehistoric Landscape. Leicester: Leicester Archaeology Monograph 20 


\section{L.P. Cooper \& W. Jarvis. MAKING \& BREAKING MICROLITHS: MIDDLE MESOLITHIC SITE, ASFORDBY, LEICS}

Gamble, C. 2001. Archaeology: The basics. London: Routledge

Gardiner, J. nd. Resource assessment: the Mesolithic in Hampshire http://thehumanjourney.net/pdf_store/sthames/ Hampshire\%20Revised\%20Mesolithic.pdf accessed 27/9/13

Gelhausen, F., Kegler, J.F. \& Wenzel, S. 2004. Latent dwelling structures in the Final Palaeolithic: Niederbieber IV, Andernach-Martinsberg 3, Berlin-Tegel IX. Notae Praehistoricae 24, 69-79

Gob, A. 1981. Le Mésolithique dans le bassin de l'Ourthe. Liège: Mémoire de la Société wallone de palethnologie 3

Goldberg, P. \& Macphail, R.I. 2006. Practical and Theoretical Geoarchaeology. Oxford: Blackwell

Ghesquière, E. 2011. Les rapports entre les deux rives de la Manche au Mésolithique Moyen (8000-6500 av J.-C.). In Les Anglais en Normandie, 37-45. Bayeux: Congrès des Sociétés Historiques et Archéologiques de Normandie 16

Guilbert, G. 2013. Before Grey Ditch: Mesolithic and later prehistoric artefacts and settlement features excavated in 1992 at Blake Acre Bradwell. Derbyshire Archaeological Journal 133, 1-113

Harding, P. 2000. A Mesolithic site at Rock Common, Washington, West Sussex. Sussex Archaeological Collections 138, 29-48

Hodge, C.A.H., Burton, R.G.O., Corbett, W.M., Evans, R., George, H., Heaven, F.W., Robson, J.D. \& Seale, R.S. 1983. Soils of England and Wales, Sheet 4 Eastern England. Southampton: Ordnance Survey, Soils of England and Wales

Jacobi, R.M. 1973. Aspects of the 'Mesolithic Age' in Great Britain. in S. Kozlowski (ed.), The Mesolithic in Europe, 237-66. Warsaw: Warsaw University Press

Jacobi, R.M. 1976. Britain inside and outside Mesolithic Europe. Proceedings of the Prehistoric Society $42,67-84$

Jacobi, R.M. 1978. Northern England in the eighth millennium b.c.: an essay. In P. Mellars (ed.), The Early Postglacial Settlement of Northern Europe, 295-332. London: Duckworth

Jacobi, R.M. 1979. Early Flandrian hunters in the southwest. Proceedings of the Devon Archaeological Society (Special Issue) 37, 48-93

Jacobi, R.M. 1981. The last hunters in Hampshire. In S.J. Shennan \& R.T. Schadla-Hall (eds), The Archaeology of Hampshire, 10-25. Winchester: Hampshire Field Club \& Archaeological Society Monograph 1

Jacobi, R.M. 2013. Chipped chert and flint. In Guilbert 2013, 28-61

Jarvis, W. 2011. Archaeological Excavations at Loughborough Road, Asfordby, Leicestershire (NGR: SK 701 192). ULAS unpublished report 2011-078

Jarvis, W. 2012. Late Mesolithic and Beaker Assemblages from Excavations at Loughborough Road, Asfordby. Transactions of the Leicestershire Archaeological and Historical Society 86, 1-35

Johansen, L. \& Stapert, D. 2000. Two 'epi-Ahrensburgian' sites in the Northern Netherlands: Oudehaske (Friesland) and Gramsbergen (Overijssel). Palaeohistoria 39/40, $1-87$

Jones, P. 2013. A Mesolithic 'Persistent Place' at North Park Farm, Bletchingley, Surrey. Woking: Surrey County Archaeological Unit Spoilheap Publications Monograph 8

Keeley, L.H. 1980. Experimental Determination of Stone Tool Uses. Chicago IL: University of Chicago Press

Keeley, L.H. 2010. The probable sexual division of labor in Magdalenian hide working: ethnological evidence. In E. Zubrow, F. Audouze \& J.G. Enloe (eds), The Magdalenian Household: Unravelling domesticity, 227-234. Albany NY: State University of New York Press Knight, D., Vyner, B. \& Allen, C. 2012. East Midlands Heritage: An Updated Research Agenda and Strategy for the Historic Environment of the East Midlands. Nottingham: Nottingham Archaeological Monograph 6

Krukowski, S. 1914. Un nouveau rebut du microlithique. Extrait des Comptes Rendus de la Société Scientifique de Varsovie 7, 14

Kwaad, F.J.P.M. \& Mücher, H.J. 1977. The evolution of soils and slope deposits in the Luxembourg Ardennes near Wilts. Geoderma 17, 1-37

Kwaad, F.J.P.M. \& Mücher, H.J. 1979. The formation and evolution of colluvium on arable land in northern Luxembourg. Geoderma 22(2), 173-92

Lang, L. \& Sicard, S. 2008. Les occupations mésolithiques des Closeaux á Rueil-Malmaison (Hauts-de-Seine). In Fagnart et al. (eds) 2008b, 65-83

Lanting, J.N., Aerts-Bijma, A.T. \& van der, Plicht, J. 2001. Dating of cremated bones. Radiocarbon 43(2A), 249-54

Leroi-Gourhan, A. 1993. Gesture and Speech. Cambridge MA: MIT Press

Lindbo, D.L., Stolt, M.H. \& Vepraskas, M.J. 2010. Redoximorphic features. In G. Stoops, V. Marcelino \& F. Mees (eds), Interpretation of Micromorphological Features of Soils and Regoliths, 129-47. Amsterdam: Elsevier

Macphail, R. 2012. Mesolithic Asfordby, Leicestershire: Soil micromorphology: Report for University of Leicester Archaeology Service Unpublished report, Institute of Archaeology, University College London

Mellars, P. 1974. The Palaeolithic and Mesolithic. In C. Renfrew (ed.), British Prehistory: a New Outline, 41-99. London: Duckworth

Mellars, P. 1976. Settlement patterns and industrial variability in the British Mesolithic. In G. de, G. Sieveking, I.H. Longworth \& K. Wilson (eds), Problems in Economic and Social Archaeology, 375-99. London: Duckworth

Mithen, S.J. 1999. Hunter-gatherers of the Mesolithic. In J. Hunter \& I. Ralston (eds), The Archaeology of Britain: An introduction from the Upper Palaeolithic to the Industrial Revolution, 33-57. London: Routledge

Murphy, C. P. 1986. Thin Section Preparation of Soils and Sediments. Berkhamsted: A.B. Academic

Myers, A. 1989. Reliable and maintainable technological strategies in the Mesolithic of mainland Britain. In R. Torrence (ed.), Time, Energy and Stone Tools, 78-91. Cambridge: Cambridge University Press 
Myers, A.M. 2006. The Mesolithic. In N.J. Cooper (ed.), The Archaeology of the East Midlands. An Archaeological Resource Assessment and Research Agenda, 51-68. Leicester: Leicester Archaeology Monograph 13

Newcomer, M.H. \& Karlin, C. 1987. Flint chips from Pincevent. In G. de, G. Sieveking \& M.H. Newcomer (eds), The Human Uses of Flint and Chert, 33-7. Cambridge: Cambridge University Press

Parker, D. 2008. An Archaeological Evaluation at Land West of Loughborough Road, Asfordby, Leicestershire (SK 701 192). ULAS unpublished report 2008-156

Pelegrin, J. 2000. Les techniques de débitage laminaire au Tardiglaciare: critères de diagnose et quelques réflexions. in B. Valentin, P. Bodu \& M. Christensen (eds), L'Europe centrale et septentrionale au Tardiglaciaire, Actes de la table-ronde internationale de Nemours, 13-16 mai 1997, 73-86. Nemours: Mémoires du Musée de Préhistoire d'Ile de France, 7

Phillips, G. 2000. An archaeological resource assessment of the Mesolithic in Northamptonshire. East Midlands Archaeological Research Framework http://www.le.ac. uk/ulas/publications/documents/10nhmeso_000.pdf

Pitts, M.W. 1978. On the shape of waste flakes as an index of technological change in lithic industries. Journal of Archaeological Science 5, 17-37

Pitts, M \& Jacobi, R.M. 1979. Some aspects of change in flaked stone industries of the Mesolithic and Neolithic in southern England. Journal of Archaeological Science 6, 163-77

Prehistoric Society 1999. Research Frameworks for the Palaeolithic and Mesolithic of Britain and Ireland. Salisbury: Prehistoric Society

Radley, J. \& Mellars, P. 1964. A Mesolithic structure at Deepcar, Yorkshire, England, and the affinities of its associated flint industries. Proceedings of the Prehistoric Society 30, 1-24

Rankine 1949. A Mesolithic Survey of the West Surrey Greensand. Farnham: Research Paper of the Surrey Archaeological Society 2

Reimer, P.J., Baillie, M.G.L., Bard, E., Bayliss, A., Beck, J.W., Blackwell, P.G., Bronk Ramsey, C., Buck, C.E., Burr, G.S., Edwards, R.L., Friedrich, M., Grootes, P.M., Guilderson, T.P., Hajdas, I., Heaton, T.J., Hogg, A.G., Hughen, K.A., Kaiser, K.F., Kromer, B., McCormac, F.G., Manning, S.W., Reimer, R.W., Richards, D.A., Southon, J.R., Talamo, S., Turney, C.S.M., Plicht, J. van der \& Weyhenmeyer, C.E. 2009. IntCal09 and Marine09 radiocarbon age calibration curves, 0-50,000 Years cal BP. Radiocarbon 51, 1111-50

Reynier, M.J. 1997. Radiocarbon dating of Early Mesolithic technologies from Great Britain. In J.-P. Fagnart \& A. Thévenin (eds), Le Tardiglaciaire en Europe $d u$ Nord-Ouest, 529-42. Paris: Éditions du CTHS

Reynier, M.J. 1998. Early Mesolithic settlement in England and Wales: some preliminary observations. In N. Ashton, F. Healy \& P. Pettitt (eds), Stone Age Archaeology: Essays in Honour of John Wymer, 174-84. Oxford: Oxbow Monograph 102/Lithic Studies Society Occasional Paper 6

Reynier, M.J. 2005. Early Mesolithic Britain: Origins, Development, and Directions. Oxford: British Archaeological Report 393
Rowley-Conwy, P. 1987. Animal bones in Mesolithic studies: recent progress and hopes for the future. In P. RowleyConwy, M. Zvelebil \& H.-P. Blankholm (eds), The Mesolithic - Recent Trends, 74-81. Sheffield: Department of Archaeology \& Prehistory, University of Sheffield

Rozoy, J.-G. 1992. Le montage des armatures sur les flèches épipaléolithiques. Revue archéologique de l'Est et $d u$ Centre-Est 43(161), 29-38

Saville, A. 1981a. Honey Hill, Elkington: A Northamptonshire Mesolithic Site. Northamptonshire Archaeology 16, 1-13

Saville, A. 1981b. Mesolithic industries in central England: an exploratory investigaton using microlith typology. Archaeological Journal 138, 49-71

Saville, A. 2008. The beginning of the later Mesolithic in Scotland. In Z. Sulgostowska \& A. Tomaszewski (eds), Man - Millennia - Environment: Studies in Honour of Romuald Schild, 207-13. Warsaw: Institute of Archaeology and Ethnology, Polish Academy of Sciences

Sergant, J., Crombe, P. \& Perdaen, Y. 2006. The 'invisible' hearths: a contribution to the discernment of Mesolithic non-structured surface hearths. Journal of Archaeological Science 33, 999-1007

SHAPE 2007. English Heritage Research Agenda: An introduction to English Heritage's research themes and programmes. London: English Heritage

Slota, P.J. Jr, Jull, A.J.T., Linick, T.W. \& Toolin, L.J. 1987. Preparation of small samples for ${ }^{14} \mathrm{C}$ accelerator targets by catalytic reduction of CO. Radiocarbon 29, 303-06

Smalley, R. 2007. Geophysical Survey Report. Asfordby, Leicestershire. Stratascan unpublished report J2398

Souffi, B. 2008. Le Mésolithique de Haute-Normandie: taphonomie et interprétation chronoculturelle. In Fagnart et al. (eds) 2008b, 135-51

Stapert, D. 1989. The ring and sector method: intrasite spatial patterns of Stone Age sites, with special reference to Pincevent. Palaeohistoria 31, 1-57

Steier, P. \& Rom, W. 2000. The use of Bayesian statistics for ${ }^{14} \mathrm{C}$ dates of chronologically ordered samples: a critical analysis. Radiocarbon 42, 183-98

Stuiver, M. \& Polach, H.A. 1977. Reporting of ${ }^{14} \mathrm{C}$ data. Radiocarbon 19, 355-63

Stuiver, M. \& Reimer, P.J. 1986. A computer program for radiocarbon age calculation. Radiocarbon 28, 1022-30

Stuiver, M. \& Reimer, P.J. 1993. Extended ${ }^{14} \mathrm{C}$ data base and revised CALIB $3.0{ }^{14} \mathrm{C}$ age calibration program. Radiocarbon 35, 215-30

Switsur, V.R. \& Jacobi, R.M. 1979. A radiocarbon chronology for the Early Postglacial stone industries of England and Wales. In R. Berger \& H.E. Suess (eds), Radiocarbon Dating, 41-68. Los Angeles CA: University of California Press

Thévenin, A. 2008. Le Mésolithique ancien et moyen de la moitié nord de la France: les grandes lignes du peplement. In Fagnart et al. (eds) 2008b, 31-50

Tringham, R., Cooper, G., Odell, G., Voytek, B. \& Whitman, A. 1974. Experimentation in the formation of edge damage: A new approach to lithic analysis. Journal of Field Archaeology 1, 171-96 


\section{L.P. Cooper \& W. Jarvis. MAKING \& BREAKING MICROLITHS: MIDDLE MESOLITHIC SITE, ASFORDBY, LEICS}

Valentin, B. 2008a. Magdalenian and Azilian lithic productions in the Paris Basin: Disappearance of a programmed economy. Arkeotek Journal 2(3), 1-54

Valentin, B. 2008b. Jalons pour une Paléohistoire des Derniers Chasseurs (XIVe-Vie millénaire avant J.-C.). Paris: Publications de la Sorbonne, Cahiers archéologiques de Paris 1,1

Vandeputte, K., Moens, L. \& Dams, R. 1996. Improved sealed-tube combustion of organic samples to $\mathrm{CO}_{2}$ for stable isotope analysis, radiocarbon dating and percent carbon determinations. Analytical Letters 29, 2761-73

Waddington, C. 2007. Mesolithic Settlement in the North Sea Basin: A case study from Howick, north-east England. Oxford: Oxbow Books

Waddington, C. 2015. Mesolithic re-colonisation of Britain following the drowning of North Sea landscapes.
In N. Ashton \& C. Harris (eds), No Stone Unturned: Papers in honour of Roger Jacobi, 221-32. London: Lithics Studies Society

Waddington, C., Bailey, G., Bayliss, A. \& Milner, N. 2007. Howick in its North Sea context. In Waddington (ed.), 2007, 203-24

Ward, G.K. \& Wilson, S.R. 1978. Procedures for comparing and combining radiocarbon age determinations: a critique. Archaeometry 20, 19-31

$\mathrm{Xu}$, S., Anderson, R., Bryant, C., Cook, G.T., Dougans, A., Freeman, F., Naysmith, P., Schnabel, C. \& Scott, E.M. 2004. Capabilities of the new SUERC 5MV AMS facility for ${ }^{14} \mathrm{C}$ dating. Radiocarbon 46, 59-64

Zvelebil, M. 1994. Plant use in the Mesolithic and its role in the transition to farming. Proceedings of the Prehistoric Society 60, 35-74

\section{RÉSUMÉ}

Fabriquer et casser des microlithes: Un site du mésolithique moyen à Asfordby, Leicestershire, de Lynden P. Cooper et Wayne Jarvis

Une prospection archéologique en amont de la construction d'un lotissement a révélé un site mésolothique dans un contexte primaire. Un foyer central était attesté par un groupe de silex et d'os calcinés, ces derniers produisant une date modélisée pour le début de l'occupation de 8220-7840 av.J.-C. cal et pour la fin de 79607530 av.J.-C. cal (probabilité de 95\%). L’industrie principale était le débitage de lamelles, les supports pour la production de microlithes. Des microlithes endommagés par impact indiquaient le re-travail des armatures de chasse tandis que l'analyse de la micro-usure d'autres outils attestait d'activités de travail des peaux et de boucherie sur le site. Ces lithes peuvent être classés dans le type d'assemblage HoneyHill sur la base de pointes de microlithes foliacées distinctives avec retouche basale inversée.

Il est bien connu qu'il s'en trouve une concentration dans le centre de l'Angleterre et on pense qu'ils sont temporellement intermédiaires entre les périodes conventionnelles du mésolithique britannique ancien et récent. On compare l'assemblage lithique à d'autres assemblages de type Honey Hill et aux assemblages lithiques de type Horsham du sud-est de l'Angleterre avec lesquels ils ont des liens. Les deux types d'assemblage sont appelés mésolithique moyen et peuvent être considérés comme faisant partie de développements plus larges au cours des périodes préboréale tardive et boréale de l'Europe du nord-ouest. Le rapide réchauffement climatique à cette période a vu les forêts d'arbres à feuilles caduques s'étendre vers le nord dans l'Europe du nord-ouest. De nouveaux écosystèmes émergeants présentaient des changements dans la configuration des ressources et les développements typotechnologiques du lithique du mésolithique moyen reflètent de nouvelles stratégies de recherche de nourriture comme des adaptations aux nouvelles opportunités offertes par les conditions de la forêt boréale. Tandis que les assemblages de type Honey Hill sont considérés comme faisant partie de ces procédés plus étendus leur signature typologique distinctive atteste de développements autochtones, régionaux de groupes humains venant occuper ce paysage. Une telle insularité culturelle peut refléter des changements dans les frontières sociales avec la réduction du champ de mobilité et l'isolation physique causée par l'élévation du niveau de la mer et la création de l'archipel britannique.

\section{ZUSSAMENFASSUNG}

Vom Machen und Zerbrechen von Mikrolithen: Eine mittelmesolithische Fundstelle in Asfordby, Leicestershire, von Lynden P. Cooper und Wayne Jarvis

Archäologische Feldarbeiten im Vorfeld von Baumaßnahmen führten zur Entdeckung eines mesolithischen Fundplatzes in ungestörter Fundlage. Eine zentrale Brandstelle wurde durch ein Cluster kalzinierter Silices und Knochen angezeigt; anhand letzterer konnte ein modelliertes Datum für den Beginn der Belegung des Platzes von 
8220-7840 cal вС und für das Ende von 7960-7530 cal вС (95\% Wahrscheinlichkeit) gewonnen werden. Die Haupttätigkeit war die Herstellung von kleinen Klingen, den Rohlingen für die Produktion von Mikrolithen. Beschädigte Mikrolithe zeigten die Überarbeitung von Jagdwaffen an, und die Mikro-Gebrauchsspurenanalyse weiterer Werkzeuge lässt Aktivitäten auf dem Fundplatz erkennen wie das Bearbeiten von Fellen und das Schlachten von Tieren. Die Lithik kann als ein Ensemble des Typs Honey Hill klassifiziert werden auf der Basis eindeutiger blattförmiger mikrolithischer Spitzen mit inversen basalen Retuschen.

Die Konzentration solcher Ensembles liegt in Mittelengland und sie gelten zeitlich als Zwischenstufe zwischen den konventionellen Perioden des britischen Frühmesolithikums und des Spätmesolithikums. Das lithische Spektrum wird sowohl mit anderen Fundensembles des Honey Hill Typs verglichen als auch mit verwandten Ensembles vom Horsham Typ aus Südostengland. Beide Typensembles werden als mittelmesolithisch bezeichnet und können als Teil generellerer Entwicklungen des Präboreals und Boreals Nordwesteuropas verstanden werden. Schnelle Klimaerwärmung in dieser Zeit führte zur nordwärts gerichteten Ausbreitung von Laubwald nach Nordwesteuropa. Es entstanden neue Ökosysteme, die Änderungen in der Zusammensetzung der Ressourcen bewirkten, und die typo-technologischen Entwicklungen der Lithik des Mittelmesolithikums reflektiert neue Strategien der Nahrungsaneignung als Anpassungen an die neuen Möglichkeiten der borealen Wälder. Während Fundensembles vom Typ Honey Hill als Teil viel generellerer Prozesse gesehen werden, spricht ihre distinktive typologische Signatur für autochthone regionale Entwicklungen mit dem Eindringen von Gruppen in diese Landschaft. Eine solche kulturelle Insularität reflektiert möglicherweise sich wandelnde soziale Grenzen mit der Reduktion des Umfangs der Mobilität und mit physischer Isolation, hervorgerufen durch den Anstieg des Meeresspiegels und die Entstehung des britischen Archipels.

\section{RESUMEN}

Haciendo y rompiendo microlitos: un yacimiento del Mesolitico medio en Asfordby, Leicestershire, por Lynden P. Cooper and Wayne Jarvis

Los trabajos arqueológicos previos al desarrollo urbanístico revelaron un yacimiento arqueológico Mesolítico en contexto primario. Se documentó un hogar central compuesto por un conjunto de sílex y huesos calcinados, cuya datación sitúa el inicio de la ocupación entre el 8220-7840 cal BC, y el final de la misma en el intervalo 7960-7530 cal вс (95\% de probabilidad). La principal actividad fue la talla de laminillas como soportes para la producción de microlitos. Los microlitos con fracturas por impacto indican una reparación de las armas de caza, mientras que el análisis de huellas de uso del resto del utillaje refleja el trabajo de la piel y la realización de actividades de carnicería en el sitio. El conjunto lítico puede ser clasificado como tipo Honey Hill en base a las distintivas puntas microlíticas foliáceas con retoque basal inverso.

Estos conjuntos presentan una clara concentración en el centro de Inglaterra y se consideran cronológicamente intermedios entre el Mesolítico inicial y final británico. Este conjunto lítico se ha comparado con otros del tipo Honey Hill y con los de tipo Horsham del sureste de Inglaterra. Ambos tipos de conjuntos se atribuyen al Mesolítico medio y pueden considerarse como parte de un desarrollo más amplio durante el final del Preboreal y el Boreal en el noroeste de Europa. La rápida mejora climática en este momento propició la expansión del bosque caducifolio hacia el noroeste de Europa. Los ecosistemas emergentes supusieron cambios en los patrones de recursos y los desarrollos tecno-tipológicos líticos del Mesolítico Medio reflejan nuevas estrategias de forrajeo como adaptación a las oportunidades que ofrece el bosque boreal. Mientras que los conjuntos del tipo Honey Hill pueden ser vistos como una parte de estos amplios procesos, su distintivo aspecto tipológico atestigua el desarrollo autóctono y regional de los grupos humanos que ocupan el paisaje. Esta particularización cultural podría reflejar límites sociales cambiantes, con una reducción de la movilidad y un aislamiento físico causado por la subida del nivel del mar y por la creación del archipiélago británico. 